\title{
28. PALYNOLOGY AND DINOCYST STRATIGRAPHY OF THE EOCENE AND OLIGOCENE IN ODP LEG 105, HOLE 647A, LABRADOR SEA ${ }^{1}$
}

\author{
Martin J. Head ${ }^{2}$ and Geoffrey Norris ${ }^{2}$
}

\begin{abstract}
Dinoflagellate cysts were recovered throughout the Paleogene succession of Hole 647A, which contains an almost complete deep-water record of early Eocene through early late Oligocene sedimentation in the Labrador Sea. Dinoflagellate cyst biostratigraphy is in general accord with that provided by other microfossil groups and is consistent with a lower Eocene age, as determined by nannofossils, for basal sediments in Hole 647A. These sediments overlie oceanic crust of Chron 24 age.

Dinocyst assemblages indicate outer neritic to oceanic conditions throughout, although the persistent occurrence of Wetzeliellaceae specimens in the lower Eocene suggests a greater influence from shelf environments during this time. Lower Eocene dinocyst assemblages are similar to coeval assemblages from the Rockall Plateau, but those from the middle to upper Eocene have mixed affinities and may be related to the intensification of the proto-Gulf Stream from middle Eocene time. Oligocene dinocyst assemblages suggest the influence of both arctic and North Atlantic water masses at this site. The presence of protoperidineacean species in the upper Eocene and Oligocene may indicate increased availability of nutrients, perhaps related to increased upwelling or the effects of water-mass mixing.

Productive samples are dominated by dinocysts and acritarchs, while sporomorphs are represented mainly by bisaccate pollen. Preservational differences within samples may reflect mixing of penecontemporaneous dinocyst populations during the Eocene, and all samples examined may have a considerable allochthonous component. Variability in relative abundance of many species during the Eocene may be related to fluctuating water-mass properties.

A total 175 dinocyst and acritarch taxa were recorded from 53 productive samples from the Paleogene. Only one $\mathrm{Pa}-$ leogene sample was barren of palynomorphs. Of three Miocene samples processed, all were barren.
\end{abstract}

\section{INTRODUCTION}

\section{Hole 647A}

Site 647 is located at $53^{\circ} 19.876^{\prime} \mathrm{N}, 45^{\circ} 15.717^{\prime} \mathrm{W}$ in the southern Labrador Sea and on the southern flank of a drift deposit known as the Gloria Drift. Hole 647A was drilled in a water depth of $3858.5 \mathrm{~m}$ and reached a total depth of 736 meters below seafloor (mbsf). The entire hole was rotary cored and terminated in $31 \mathrm{~m}$ of basaltic basement, overlain by lower Eocene sediments. The sedimentary record of Hole 647A extends from lower Eocene to Holocene, with significantly large hiatuses representing part or all of the upper Oligocene, most of the Miocene, and lower Pliocene. However, the lower $564 \mathrm{~m}$ represents a nearly complete sedimentary sequence from lower Eocene to lower Oligocene, with the exception of a hiatus representing the lower middle Eocene (and possible uppermost lower Eocene) that occurs across the lower/middle Eocene boundary.

\section{General Background and Objectives}

Today, the Labrador Sea is the site of a mixed-water counterclockwise gyre in which cold arctic waters from the Baffin Current and East Greenland Current combine with warm Atlantic water from the North Atlantic Current (known also as the North Atlantic Drift). The Labrador Sea and Baffin Bay may have allowed arctic waters into the North Atlantic since the Late Cretaceous, and an important objective of Hole $647 \mathrm{~A}$ was to determine the history of water-mass development in the southern Labrador Sea. Site 647 was placed just to the south of a thick late Cenozoic bottom-current ("drift") deposit-the Gloria Drift-where sedimentary cover was thin enough to allow recovery of the entire Paleogene sedimentary sequence and penetra-

${ }^{1}$ Srivastava, S. P., Arthur, M., Clement, B., et al., 1989. Proc. ODP, Sci. Results, 105: College Station, TX (Ocean Drilling Program).

2 Department of Geology, University of Toronto, Ontario M5S 3B1, Canada. tion of oceanic crustal basement (Fig. 1). In addition, this site is far enough south to be sensitive to northward incursions of the North Atlantic Current. Site 647 also lies in a position that is sheltered by the Gloria Drift from south and southwesterly flowing bottom-water currents. These currents were responsible for widespread erosion of sediments in the eastern North Atlantic during the late Eocene to early Oligocene. Site 647 also lies in a part of the Labrador Sea where magnetic anomalies are well developed, thus allowing for their calibration with the magnetic time scale to be tested by the chronostratigraphy of Hole 647A.

A short hiatus spanning the early/middle Eocene boundary has been inferred from the sedimentary rate curve at this site. Elsewhere, the early/middle Eocene boundary coincides with an increased surface-water organic productivity and a temperature decrease of $1^{\circ}$ to $2^{\circ} \mathrm{C}$ in both surface and bottom waters of the Atlantic (Kaminski, Gradstein, and Berggren, this volume, and references therein). Hiatuses spanning the early/middle Eocene boundary occur in a number of DSDP sites in the western and northwestern North Atlantic and may be related to an intensification of the proto-Gulf Stream and a decrease in eustatic sea level (Poag, 1987), which may in turn be related to a reduction in the rate of seafloor spreading in the North Atlantic and Labrador Sea (Miller et al., 1987; Kaminski, Gradstein, and Berggren, this volume). At Site 647 the hiatus is not defined precisely by calcareous microfossils as these are absent across the boundary. However, this hiatus may reflect an interval of about 6 Ma. A specialized benthic foraminiferal assemblage and increased total organic carbon near the early/middle Eocene boundary at Site 647 support a hypothesis of increased organic productivity across the boundary in the Atlantic (Kaminski, Gradstein, and Berggren, this volume).

Apparently, Hole 647 has a complete sedimentary record from upper middle Eocene through lower Oligocene sediments. This contrasts with DSDP sites in the eastern North Atlantic, where the sedimentary record is interrupted by a hiatus near the Eocene/Oligocene boundary. At present, cold bottom water from 


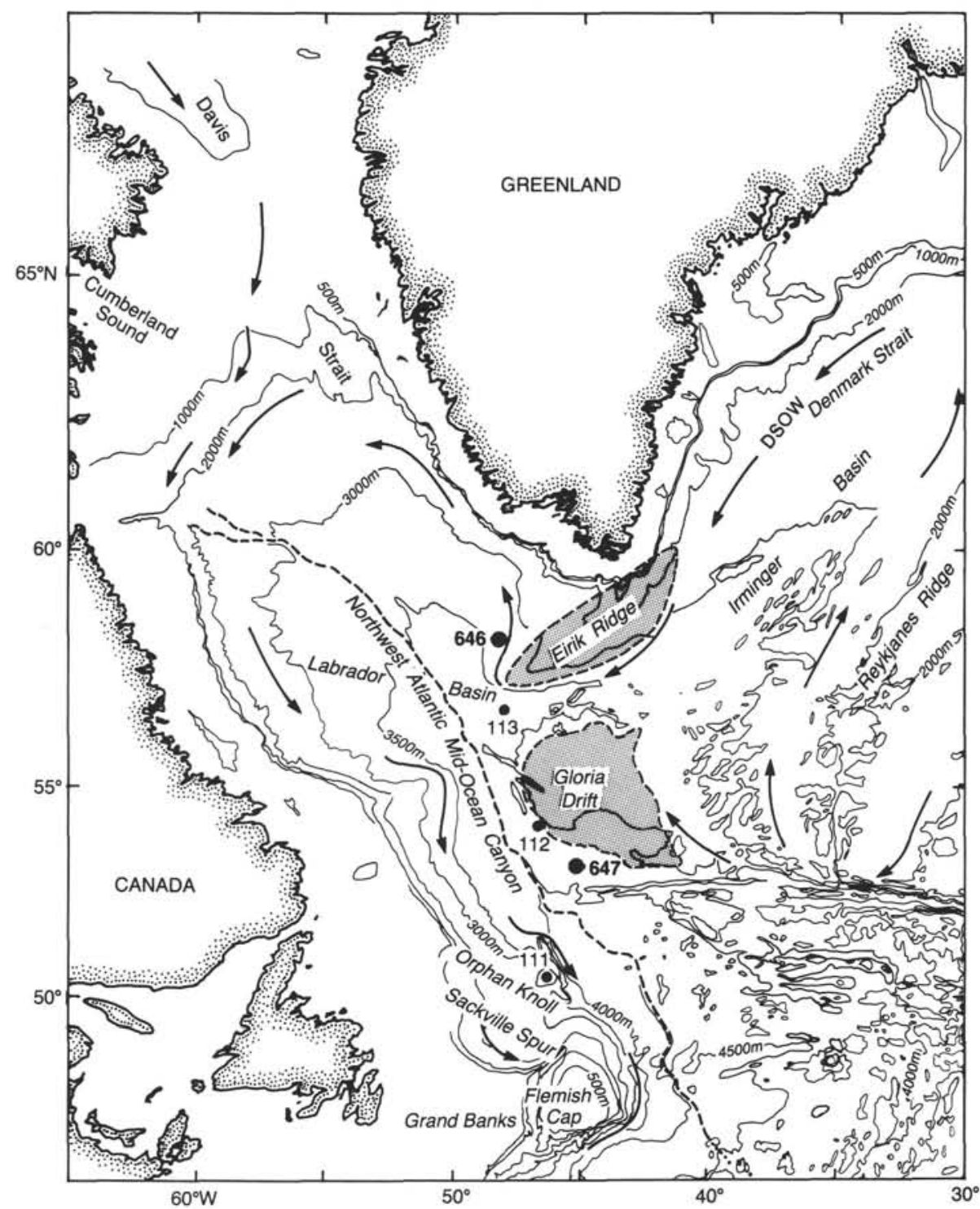

Figure 1. Generalized bathymetric map of the Labrador Sea. Location of Site $647\left(53^{\circ} 19.876^{\prime} \mathrm{N}\right.$, $45^{\circ} 15.717^{\prime} \mathrm{W}$ ) is shown at a depth of $3858.5 \mathrm{~m}$ in the southern Labrador Sea and just south of the Gloria Drift. Other late Cenozoic "drift" (bottom current) deposits are also shown (shaded) together with the direction of modern bottom currents (after McCave and Tucholke, 1986), as indicated by arrows, and the location of other DSDP/ODP sites in the Labrador Sea. Depth contours are in meters. DSOW = Denmark Strait Overflow Water.

the Norwegian Sea passes southwestward through the Denmark Strait between Greenland and Iceland and flows parallel to the East Greenland continental slope. This is known as Denmark Strait Overflow Water (DSOW), which together with associated bottom currents was responsible for the formation of major sedimentary "drift" deposits in the northern North Atlantic, including the Eirik and Gloria drifts (Fig. 1). The main phase of drift development in this area occurred during the late Cenozoic. From as early as the late Eocene, however, important bottom-water circulation was present in the northern North Atlantic. This circulation may have been related to global cooling during the late Eocene and, in particular, to the subsidence of the Greenland-Scotland Ridge during the latest Eocene, which initiated the flow of dense arctic bottom water from the Norwegian Sea and into the North Atlantic (Miller and Tucholke, 1983). Bottom-water flow in the North Atlantic was evidently influenced by seafloor topography, which may have protected sediments at Site 647 from erosion. Nevertheless, evidence at Site 647 of increased bottom-water circulation is recorded by a change from an Eocene agglutinated benthic foraminiferal assemblage to one that is predominantly calcareous in the early Oligocene and reflects the first appearance of cool, nutrientpoor deep water in the southern Labrador Sea (Kaminski, Gradstein, and Berggren, this volume). Also, planktonic foraminifers and calcareous nannofossils from Hole 647A indicate a surfacewater temperature decline from temperate with warm temperate incursions during the middle and late Eocene to cool temperate during the Oligocene. Thus, the uninterrupted sedimentary record through upper Eocene into lower Oligocene at Site 647 provides us with an important opportunity to evaluate paleoceanographic and biostratigraphic developments across the boundary.

This chapter describes the results of a preliminary study of dinoflagellate cysts and acritarchs (also reported in Head et al., 
1986), as part of an ongoing investigation into the Paleogene palynology of Site 647 . The primary objectives of this phase of the investigation were as follows:

1. To produce a first-order biostratigraphy of Hole $647 \mathrm{~A}$ and, particularly, to provide a biostratigraphic age for sediments immediately overlying putative Chron 24 age basalts near its base.

2. To provide a paleoenvironmental interpretation of Paleogene dinoflagellate assemblages.

3. To record and illustrate some of the more morphologically distinct and stratigraphically/ecologically important dinoflagellate and acritarch species.

\section{Other Paleogene Palynological Studies}

A number of studies of Eocene dinoflagellates has been published from northwestern Europe onshore localities, and several zonal schemes have developed from these, of which the most important is that based on species of the Wetzeliellaceae lineage (Costa and Downie, 1976, 1979a; Chateauneuf and Gruas-Cavagnetto, 1978; Bujak, 1979). However, many species of Wetzeliellaceae occur most commonly in estuarine and inner-shelf sediments. The utility of the Wetzeliellaceae zonal scheme thus is greatly curtailed in deeper water and more fully marine sediments, where zonal species may be absent or occur intermittently. Other Paleogene dinoflagellate species complexes, recognized as being useful for biostratigraphy, include the Phthanoperidinium complex (Bujak and Davies, 1983, p. 76-83) and the Eatonicysta-Areosphaeridium-Glaphyrocysta lineage (Eaton, 1971; Bujak, 1976), which together include species that are widely distributed across the shelf. Despite this, no global standard zonal scheme is presently recognized. Instead, most scientists prefer to erect local or regional zonal schemes (as summarized in Williams and Bujak, 1985), particularly in more offshore locations. This no doubt reflects the prevalent ecological, environmental, and provincial control over the composition of Paleogene dinoflagellate assemblages. In view of the deep-water location of Site 647 and the absence of a local, precisely ageconstrained dinoflagellate zonal scheme, the biostratigraphic approach used both onboard the JOIDES Resolution (de Vernal and Head, in Srivastava, Arthur, et al., 1987) and in this study has been to base age determinations upon maximum ranges of selected taxa. For the lower Eocene, however, emphasis has been placed upon comparison with local ranges for the Rockall Plateau (Costa and Downie, 1979b; Brown and Downie, 1984) and Goban Spur (Brown and Downie, 1985), which were near the vicinity of Site 647A during the early Paleogene (see Fig. 2). We presume that the total dinoflagellate data accumulated so far for this hole will attain greater biostratigraphic significance as world ranges become known more precisely.

Of the many published Paleogene dinoflagellate studies, a small proportion have good chronostratigraphic control. Those studies that have been most useful for evaluating dinoflagellate stratigraphic ranges and that are constrained by nannofossil, planktonic foraminiferal, or magnetostratigraphic control are as follows:

1. Northwestern Europe: Eaton (1976), Costa and Downie (1976), Bujak (1976, 1979b), Bujak et al. (1980), Chateauneuf (1980; using biostratigraphic control of Aubry, 1985), Townsend and Hailwood (1985), Aubry et al. (1986), Murray et al. (1987). Also useful are Benedek and Müller (1974, 1976).

2. Eastern North Atlantic: Costa and Downie (1979b; using biostratigraphic control of Müller, 1979; Hailwood et al., 1979); Morton et al. (1983); Brown and Downie (1984; using biostratigraphic control of Backman, 1984); and Brown and Downie
(1985; using biostratigraphic control of Müller, 1985; Snyder and Waters, 1985).

Compilations of stratigraphic ranges given in Costa (1985) and Williams and Bujak (1985) and biozones given in Haq et al. (1987) were also helpful during the preliminary assessment of species ranges. Other references that are considered useful, although they do not necessarily have good age control, include the following:

1. Norwegian-Greenland Sea: Manum (1976); Manum et al. (in press).

2. Spitsbergen: Manum (1960); Head (1984); Manum and Throndsen (1986).

3. Eastern Greenland: Soper et al. (1976a); Soper et al. (1976b); Soper and Costa (1978).

4. Western Greenland: Costa, pers. comm., in Rolle (1985).

5. Arctic Canada: Brideaux (1976); Ioannides and McIntyre (1980); McNeil et al. (1982); Mudie (1985); Norris (1986).

6. Offshore Eastern Canada: Williams (1975); Williams and Brideaux (1975); Williams and Bujak (1977b); Ioakim (1979); Barss et al. (1979); D'Iorio (1986); Bujak et al. (1987). (Note that Williams and Bujak's [1977b] postulated "late Eocene" Diphyes colligerum Zone here is taken to include the upper middle Eocene (Bartonian), following the scheme of Berggren et al. [1985].)

7. Alaska, Bering Sea, and northern North Pacific: Bujak (1984); Ager et al. (1986).

8. Eastern U.S.A.: Gibson et al. (1980; using nannofossil correlations therein); Edwards (1977; using correlations of Bybell, 1975); Frederiksen (1980, Fig. 3); Edwards (1984; using correlations of DiMarzio, 1984); Edwards et al. (1984; using correlations of Gibson et al., 1980, and Gibson and Bybell, 1984); Edwards (1986); Goodman (1979 and 1984; using correlations of Gibson et al., 1980, and Gibson and Bybell, 1984).

There are fewer published records for Oligocene dinoflagellate assemblages than for the Eocene. This is partly a consequence of a hiatus in the early to middle Oligocene sections in the North Atlantic, a marine regression over parts of northwestern Europe during the early Oligocene, and a global lowstand in sea level during the "middle" and late Oligocene. Oligocene dinoflagellate biostratigraphy thus presently offers lower resolution than for the Eocene. Useful Oligocene dinoflagellate publications (in addition to some of those listed above) include the following: Benedek (1972, 1980); Benedek and Sarjeant (1981); Sarjeant (1983, 1984); Biffi and Grignani (1983); Goodman and Ford (1983); Liengjarern et al. (1980); Powell (1986a, 1986b); Stover (1977); Edwards (1986); and Biffi and Manum (1988).

\section{Lithostratigraphy and Seismic Stratigraphy for Hole 647A}

The lithostratigraphy and seismic stratigraphy for Hole 647A, as given below, is summarized from Srivastava, Arthur, et al. (1987).

The lowest $31-\mathrm{m}$ interval in Hole $647 \mathrm{~A}$ represents one or more homogeneous basalt flows and has a chilled upper surface. The thickness of this basalt (at least $31 \mathrm{~m}$ ) suggests oceanic crust, rather than a sill.

Lithologic Unit IV (Cores 105-647A-56R to -71R; 530.3-699 mbsf) immediately overlies the basaltic basement and is of early to middle Eocene age. Sediments are generally claystones or foraminifer- and nannofossil-bearing claystones, and are colorbanded with alternating dusky red and light red to green. Sediments are weakly to moderately bioturbated. Joints and fault surfaces are common throughout Unit IV and are lined by quartz 


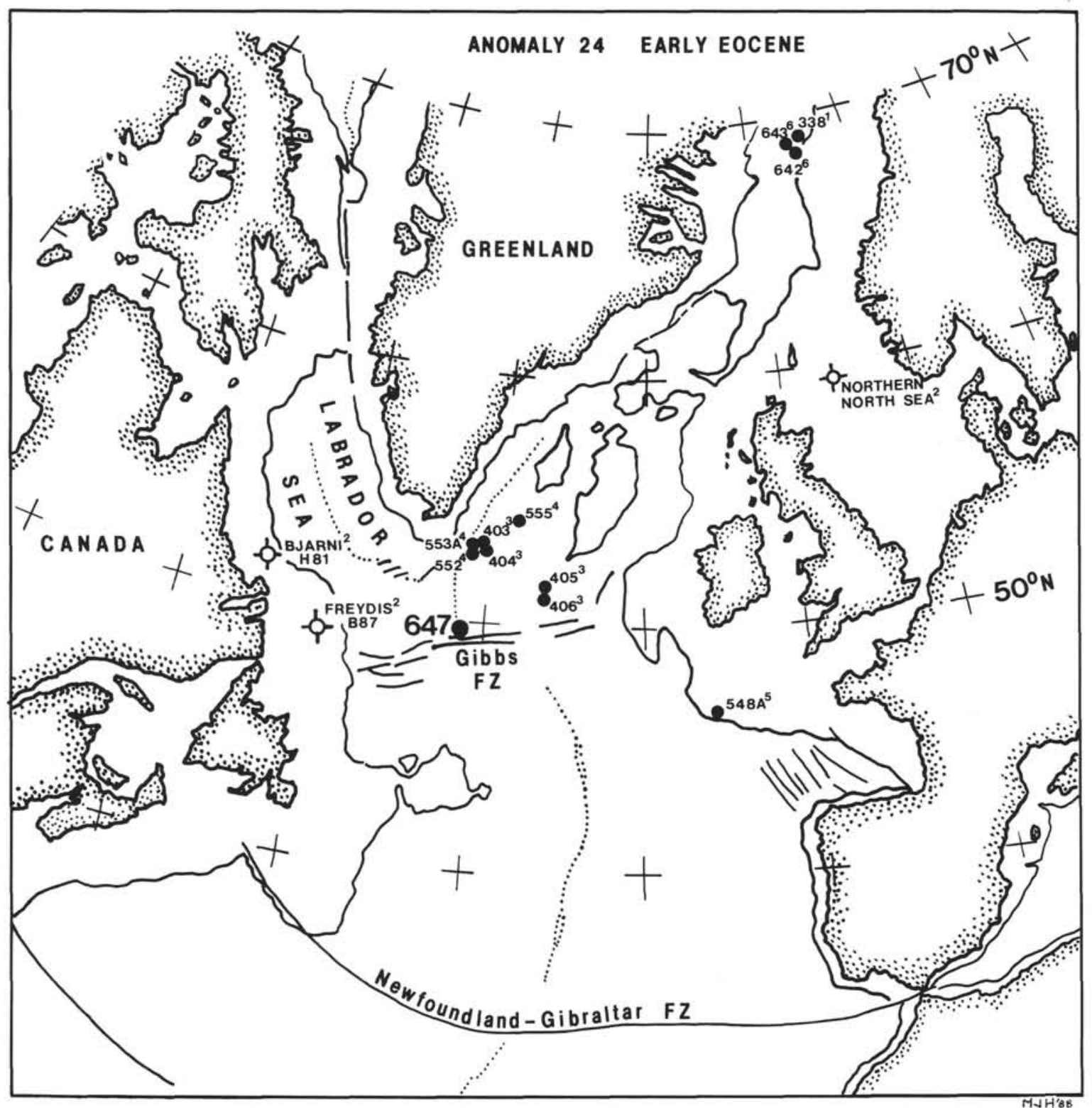

Figure 2. Palinspastic map of the North Atlantic and adjacent areas at $56 \mathrm{Ma}$ (magnetic anomaly 24: early Eocene), based on about $94 \%$ present Earth diameter (from Owen, 1983, map 27), showing the 1000-m isobath, major fracture zones, and early Eocene axial spreading ridges (dotted). Estimated locations are given for Site 647 and selected other offshore wells for which Paleogene dinocyst data are available (i.e., ${ }^{1}$ Manum, 1976; ${ }^{2}$ Ioakim, $1979 ;{ }^{3}$ Costa and Downie, $1979 ;{ }^{4}$ Brown and Downie, 1984; ${ }^{5}$ Brown and Downie, 1985; ${ }^{6}$ Manum et al., in press).

or calcite near the basalt contact, while the lowest $10 \mathrm{~cm}$ of sediment is bleached. These features suggest hydrothermal alteration of the basal sediments, as well as a penecontemporaneous age for oceanic crust and immediately overlying sediment in Hole 647A. Higher in Unit IV, diagenetic activity may be pronounced and probably is associated with low sedimentation rates.

Sediments of Unit IV are hemipelagic and were deposited under low accumulation rates. The presence of bioturbation indicates oxygenated bottom waters during sedimentation. The variable, though generally low, content of biogenic carbonate suggests variable surface-water productivity and/or carbonate dissolution effects.

Lithologic Unit III (Cores 105-647A-15R to -55R; 135.4$530.3 \mathrm{mbsf}$ ) is of early Oligocene to middle Eocene age and overlies Unit IV. Sediments in Unit III are mainly greenish-gray to light greenish-gray biogenic clays and clayey oozes (although these are well indurated below about $165 \mathrm{mbsf}$ ), with biogenic carbonate predominating over biogenic silica. Variability in the biogenic carbonate/silica ratio allows Unit III to be subdivided as follows: Subunit IIIC (Cores 105-647A-26R to -55R; 241.1530.3 mbsf; virtually no biogenic silica, but abundant nannofossils and, locally, foraminifers), Subunit IIIB (Cores 105-647A$23 \mathrm{R}$ to $-25 \mathrm{R} ; 212.3-241.1 \mathrm{mbsf}$; almost no biogenic carbonate, but $25 \%$ to $>50 \%$ biogenic silica), and Subunit IIIA (Cores 105-647A-15R to -22R; 135.4-212.3 mbsf; biogenic carbonate/ silica ratio is $2: 1$ ). This variability in biogenic components probably is mainly the result of differential preservation.

Sediments of Unit III are hemipelagic and accumulated under high sedimentation rates of about $40 \mathrm{~m} / \mathrm{m}$.y. Primary compositional lamination is rare in Unit III, and the terrigenous (i.e., clay) component was probably supplied in suspension by weak bottom currents. Sediments are moderately to strongly 
bioturbated throughout, indicating oxygenated bottom waters during sedimentation.

Three seismic units were recognized in Hole 647A, and the lowest two of these (seismic Units 2 and 3) are of Paleogene age. Seismic Unit 2 correlates with lithologic Subunits IIIA and IIIB and thus is of early Oligocene age. Seismic Unit 3 correlates with lithologic Subunit IIIC and lithologic Unit IV and thus is of early Eocene to early Oligocene age. Reflector "R4," which occurs within the upper part of seismic Unit 3 (at 251.1 mbsf: lower Oligocene), corresponds to a change from siliceous to calcareous claystones and does not appear to represent an unconformity. In fact, unlike the Northeast Atlantic (Roberts et al., 1979), there is no seismic indication that major onset of strong bottom circulation occurred at or near the Eocene/Oligocene boundary at Site 647 .

\section{Biostratigraphy}

Calcareous nannofossils, dinoflagellates, pollen and spores, and planktonic and benthic foraminifers occur throughout the recovered Paleogene sediments of Hole 647A, while diatoms and radiolarians are more or less restricted to the uppermost Eocene and Oligocene. Nannofossils and planktonic foraminifers provide the basis for biostratigraphy and indicate a nearly continuous sequence from middle lower Eocene (nannofossil Zone NP11; planktonic foraminiferal Zones P8 and P7) to lower Oligocene (Zone NP24). However, an interval from Cores 105-647A-63R through -65R, which is barren of both nannofossils and planktonic foraminifers and occurs between nannofossil Zones NN13 and NN15, contains a hiatus in which the early middle Eocene sequence is missing, as indicated from the sedimentation-rate curve.

Details concerning the biostratigraphy of Hole 647A are given in the "Dinocyst Stratigraphy and Age" section (this chapter). The stratigraphic scheme used here follows that of Berggren et al., 1985, as adopted by the Leg 105 Scientific Party.

\section{METHODS}

Samples were processed by the method outlined in Head et al. (b, this volume). Additional samples, supplied by M.A. Kaminski, are indicated by an asterisk after the sample number in Tables 3A and 3B (backpocket fold-out) and were processed using a gravity-settling method developed by Head and Kaminski to separate dinoflagellates from foraminifers, as follows. Samples were cleaned, dried, and weighed, and then boiled in a 1-L beaker of $1 \%$ (i.e., $10 \mathrm{~cm}^{3}$ dry vol/L) Calgon ${ }^{\mathrm{TM}}$ (sodium hexametaphosphate) solution. The disaggregated sample was allowed to settle for about $30 \mathrm{~s}$, when the suspension containing dinoflagellates was decanted. This was done several times, and the residue containing foraminifers was checked for remaining dinoflagellates using a binocular microscope. This method provided good separation of dinoflagellates from foraminifers, except that a small proportion of the denser dinoflagellates (notably Thalassiphora pelagica) may not have been recovered. The dinoflagellate suspension was later settled out and processed using the standard method. These particular samples were used in this study to increase sampling resolution in the lower part of Hole $647 \mathrm{~A}$ and are part of an ongoing collaborative study with M. A. Kaminski.

Nearly all samples yielded clean residues after brief oxidation (dilute $\mathrm{HNO}_{3}$ for about $20 \mathrm{~s}$ ). However, the quantity of residue obtained was generally low, and in some samples was contained on one or two microscope slides. For each sample, a single slide was scanned under the microscope for dinoflagellates.

\section{RESULTS OF HOLE 647A}

Of the 54 samples processed from the Paleogene of Hole $647 \mathrm{~A}$, all except one were productive. Marine palynomorphs dominate most samples, while the sporomorph component is composed mainly of bisaccate pollen. Preservation of dinoflagellates is moderate to good in most productive samples. Three samples were processed from the Miocene; all were barren of palynomorphs.
A total of 175 marine palynomorph species (mostly dinocysts) were recorded in this study and are listed in Table 1. Their stratigraphic distribution in the Paleogene of Hole 647A is given in Table 3A (back pocket; ordered by ascending lowest occurrences) and Table $3 \mathrm{~B}$ (back pocket; ordered by ascending highest occurrences). Those species of uncertain identity that occur rarely

Table 1. Alphabetical index of marine palynomorph species recorded in this study of the Paleogene of Hole 647A.

\begin{tabular}{|c|c|c|}
\hline $\begin{array}{c}\text { Table } \\
3 \mathrm{~A}\end{array}$ & $\begin{array}{c}\text { Table } \\
\text { 3B }\end{array}$ & Marine palynomorph species \\
\hline 130 & 145 & Acritarch sp. 1 [Pl. 6, Figs. 7, 8] \\
\hline 174 & 174 & Acritarch sp. 2 [Pl. 6, Fig. 12] \\
\hline 127 & 87 & Acritarch sp. 3 [PI. 10, Fig. 3] \\
\hline 98 & 97 & cf. Acritarch sp. 1. of Head et al., c, this vol. [Pl. 6, Fig. 13] \\
\hline 46 & 12 & Adnatosphaeridium multispinosum \\
\hline 1 & 10 & Adnatosphaeridium robustum [P1. 13, Fig. 3] \\
\hline 69 & 37 & Alisocysta sp. cf. A. ornata [Pl. 6, Fig. 6] \\
\hline 58 & 63 & Alisocysta sp. 1 [Pl. 6, Fig. 10] \\
\hline 25 & 4 & Apectodinium sp. cf. A. quinquelatum \\
\hline 22 & 3 & Areoligera senonensis \\
\hline 86 & 120 & Areosphaeridium arcuatum \\
\hline 71 & 66 & Areosphaeridium diktyoplokus [Pl. 13, Figs. 5, 9] \\
\hline 109 & 130 & Areosphaeridium pectiniforme \\
\hline 93 & 43 & Batiacasphaera sp. cf. B. hirsuta [PI. 6, Fig. 16] \\
\hline 136 & 90 & Batiacasphaera compta \\
\hline 101 & 161 & Batiacasphaera micropapillata s.l. [PI. 6, Figs. 14, 15] \\
\hline 88 & 38 & Batiacasphaera sp. A [Pl. 6, Figs. 9, 11] \\
\hline 106 & 83 & Batiacasphaera sp. B [Pl. 6, Figs. 3, 4] \\
\hline 125 & 75 & Batiacasphaera sp. C [Pl. 6, Fig. 2] \\
\hline 73 & 32 & Ceratiopsis depressa \\
\hline 14 & 22 & Ceratiopsis sp. A [Pl. 12, Fig. 13] \\
\hline 173 & 173 & Chiropteridium lobospinosum [PI. 5, Fig. 6] \\
\hline 161 & 170 & Chiropteridium mespilanum [Pl. 5, Figs. 3, 6] \\
\hline 82 & 36 & Chytroeisphaerida sp. 1 [Pl. 6, Figs. 1, 5] \\
\hline 102 & 162 & Cordosphaeridium cantharellum [Pl. 13, Fig. 15] \\
\hline 121 & 72 & Cordosphaeridium sp. cf. C. funiculatum [PI. 8, Figs. 13, 14] \\
\hline 123 & 100 & Cordosphaeridium funiculatum \\
\hline 133 & 79 & C. funiculatum sensu Williams and Bujak, 1977b [Pl. 8, Fig. 5] \\
\hline 15 & 71 & Cordosphaeridium gracile [PI. 13, Fig. 13] \\
\hline 33 & 30 & Cordosphaeridium inodes [PI. 13, Fig. 14] \\
\hline 59 & 158 & Cordosphaeridium minimum \\
\hline 67 & 82 & C. minimum sensu Eaton 1976 (?) [PI. 11, Figs. 2, 3] \\
\hline 91 & 50 & Cordosphaeridium callosum [PI. 7, Fig. 15] \\
\hline 100 & 106 & Corrudinium incompositum [Pl. 3, Fig. 15] \\
\hline 17 & 77 & Corrudinium sp. 1 [Pl. 3, Figs. 4, 12, 13] \\
\hline 52 & 81 & Corrudinium sp. 2 [Pl. 3, Fig. 14] \\
\hline 74 & 69 & Corrudinium sp. 3 [Pl. 3, Fig. 16] \\
\hline 6 & 68 & Cribroperidinium giuseppei \\
\hline 158 & 149 & Cribroperidinium tenuitabulatum \\
\hline 103 & 163 & Dapsilidinium pseudocolligerum [PI. 11, Fig. 10] \\
\hline 90 & 42 & Dapsilidinium simplex \\
\hline 83 & 46 & Dapsilidinium sp. A [PI. 11, Fig. 6] \\
\hline 112 & 107 & Deflandrea heterophlycta [Pl. 12, Fig. 5] \\
\hline 110 & 139 & Deflandrea leptodermata [PI. 12, Figs. 1, 2] \\
\hline 62 & 26 & Deflandrea oebisfeldensis (reworked?) [PI. 12, Fig. 6] \\
\hline 37 & 137 & Deflandrea phosphoritica \\
\hline 32 & 17 & Deflandrea sp. cf. D. sagittula [P]. 12, Fig. 3] \\
\hline 166 & 171 & Deflandrea spinulosa \\
\hline 2 & 34 & Dinocyst? sp. A [Pl. 13, Fig. 11] \\
\hline 115 & 99 & Dinocyst sp. B [PI. 2, Figs. 5, 6] \\
\hline 131 & 166 & Dinocyst sp. C [Pl. 4, Figs. 1, 2] \\
\hline 41 & 29 & Dinocyst sp. D [Pl. 11, Fig. 7] \\
\hline 63 & 27 & Dinocyst sp. E \\
\hline 38 & 7 & Dinocyst sp. F [PI. 13, Fig. 10] \\
\hline 45 & 157 & Dinopterygium cladoides sensu Morgenroth, 1966 \\
\hline 28 & 57 & Diphyes colligerum [PI. 12, Fig. 12] \\
\hline 79 & 35 & Diphyes sp. A [PI. 12, Fig. 8] \\
\hline 107 & 84 & Distatodinium sp. cf. D. craterum [PI. 5, Fig. 8] \\
\hline 151 & 116 & D. paradoxum sensu Gocht, (1969, Figs. 5, 6) [PI. 5, Fig. 7] \\
\hline 134 & 80 & Distatodinium scariosum [Pl. 10, Fig. 10] \\
\hline 13 & 16 & Dracodinium? condylos \\
\hline 12 & 2 & Dracodinium? sp. cf. D? condylos [PI. 1, Fig. 6] \\
\hline 55 & 25 & Duosphaeridium sp. cf. D. rugosum [PI. 12, Fig. 4] \\
\hline 23 & 13 & Eatonicysta ursulae [PI. 9, Fig. 9] \\
\hline 80 & 52 & Elytrocysta sp. A [Pl. 3, Figs. 10, 11] \\
\hline 72 & 104 & Elytrocysta sp. of Goodman and Ford, 1983 [Pl. 3, Figs. 1-3] \\
\hline 149 & 148 & Gelatia inflata [P]. 4, Fig. 5] \\
\hline 167 & 134 & Glaphyrocysta semitecta [PI. 5, Fig. 1] \\
\hline
\end{tabular}


Table 1 (continued).

\begin{tabular}{|c|c|c|}
\hline $\begin{array}{l}\text { Table } \\
3 \mathrm{~A}\end{array}$ & $\begin{array}{c}\text { Table } \\
\text { 3B }\end{array}$ & Marine palynomorph species \\
\hline 155 & 131 & Glaphyrocysta sp. A [Pl. 5, Fig. 2] \\
\hline 104 & 48 & Gochtodinium spinulum [PI. 1, Figs. 4, 5] \\
\hline 57 & 49 & Gonyaulacysta sp. 1 [Pl. 10, Fig. 9] \\
\hline 113 & 67 & Hemiplacophora semilunifera [PI. 5, Figs. 9, 10] \\
\hline 114 & 74 & Heteraulacacysta porosa [PI. 8, Fig. 8] \\
\hline 94 & 44 & Heteraulacacysta sp. A [Pl. 8, Fig. 15] \\
\hline 42 & 54 & $\begin{array}{l}\text { Heteraulacacysta sp. A of Costa and Downie, 1979b [Pl. 9, } \\
\text { Fig. 1] }\end{array}$ \\
\hline 76 & 113 & Histiocysta spp. of Goodman and Ford, 1983 [PI. 3, Figs. 5-9] \\
\hline 152 & 117 & Homotryblium pallidum \\
\hline 51 & 62 & Homotryblium tenuispinosum \\
\hline 30 & 11 & Homotryblium sp. A [PI. 11, Fig. 5] \\
\hline 143 & 102 & Homotryblium? sp. B [P]. 13, Fig. 6] \\
\hline 92 & 58 & Horologinella? spinosa \\
\hline 119 & 114 & Horologinella? spinosa (4 lobed) \\
\hline 60 & 159 & Hystrichokolpoma cinctum [Pl. 12, Fig. 11] \\
\hline 31 & 15 & $\begin{array}{l}\text { Hystrichokolpoma globulum Michoux, } 1985 \text { [Pl. 12, Figs. 9, } \\
\text { 10] }\end{array}$ \\
\hline 56 & 45 & Hystrichokolpoma granulatum [PI. 13, Fig. 2] \\
\hline 116 & 164 & Hystrichokolpoma rigaudiae \\
\hline 44 & 60 & Hystrichokolpoma unispinum [PI. 11, Fig. 9] \\
\hline 61 & 21 & Hystrichosphaeropsis sp. A [PI. 2, Figs. 4, 7, 8] \\
\hline 64 & 28 & Hystrichosphaeropsis sp. B [PI. 2, Figs. 1, 2, 3] \\
\hline 5 & 40 & Hystrichostrogylon membraniphorum \\
\hline 159 & 150 & Impagidinium aculeatum \\
\hline 19 & 119 & Impagidinium dispertitum [P1. 10, Fig. 15] \\
\hline 50 & 144 & Impagidinium? pallidum [Pl. 10, fig. 13] \\
\hline 172 & 153 & Impagidinium paradoxum \\
\hline 120 & 141 & Impagidinium patulum \\
\hline 142 & 147 & Impagidinium velorum [PI. 10, Fig. 11] \\
\hline 18 & 94 & Impagidinium sp. A [Pl. 10, Fig. 16] \\
\hline 141 & 108 & Impagidinium sp. B [Pl. 10, Fig. 4] \\
\hline 126 & 76 & Impagidinium sp. C [Pl. 10, Fig. 14] \\
\hline 77 & 160 & Impagidinium? sp. D [Pl. 8, Figs. 9, 10, 11] \\
\hline 7 & 93 & Impagidinium spp. \\
\hline 81 & 56 & Impletosphaeridium luxurium [PI. 8, Fig. 1] \\
\hline 144 & 168 & Invertocysta sp. [PI. 4, Figs. 3, 4] \\
\hline 36 & 95 & Kisselovia coleothrypta [PI. 1, Fig. 1] \\
\hline 35 & 6 & Kisselovia crassoramosa [Pl. 1, Fig. 2] \\
\hline 47 & 24 & Kisselovia edwardsii sensu Caro, 1973 [PI. 1, Fig. 3] \\
\hline 140 & 101 & Lentinia serrata \\
\hline 20 & 127 & Linguiodinium machaerophorum \\
\hline 53 & 19 & Litosphaeridium sp. A [PI. 11, Figs. 4, 8] \\
\hline 78 & 33 & Litosphaeridium? sp. B [Pl. 11, Fig. 11] \\
\hline 145 & 109 & Lophocysta sp. 1 [Pl. 4, Figs. 7, 8] \\
\hline 117 & 70 & Lophocysta sp. 2 [PI. 4, Figs. 6, 9] \\
\hline 156 & 132 & Membranophoridium aspinatum [PI. 5, Fig. 4] \\
\hline 26 & 14 & Membranophoridium sp. [PI. 6, Fig. 17] \\
\hline 75 & 96 & Nematosphaeropsis sp. cf. $N$. labyrinthea \\
\hline 146 & 110 & Nematosphaeropsis lemniscata \\
\hline 24 & 136 & Nematosphaeropsis? sp. 1 [Pl. 8, Fig. 6] \\
\hline 157 & 133 & Nematosphaeropsis? sp. 2 [PI. 8, Figs. 3, 4, 7] \\
\hline 132 & 167 & Operculodinium centrocarpum s.s. \\
\hline 4 & 31 & Operculodinium sp. cf. O. centrocarpum [Pl. 13, Fig. 12] \\
\hline 54 & 20 & Operculodinium sp. 1 [PI. 13, Fig. 7] \\
\hline 84 & 47 & Operculodinium sp. 2 [Pl. 13, Fig. 4] \\
\hline 21 & 128 & Operculodinium spp. \\
\hline 10 & 154 & Palaeocystodinium golzowense \\
\hline 150 & 169 & Pentadinium laticinctum imaginatum \\
\hline 111 & 140 & Pentadinium spp. \\
\hline 154 & 121 & Phelodinium sp. 1 [Pl. 7, Fig. 11] \\
\hline 162 & 122 & Phelodinium sp. 2 [PI. 7, Figs. 12?, 16] \\
\hline 137 & 91 & Phelodinium sp. 3 [PI. 7, Figs. 5, 9] \\
\hline 139 & 146 & Phelodinium sp. 4 [PI. 7, Fig. 6] \\
\hline 128 & 88 & Phelodinium sp. 4? [P1. 7, Fig. 7] \\
\hline 160 & 151 & Phelodinium sp. 5 [Pl. 8, Fig. 12] \\
\hline 89 & 39 & Phthanoperidinium? brooksii $[\mathrm{Pl}$. 10, Figs. 1, 2] \\
\hline 95 & 59 & Phthanoperidinium sp. cf. P. echinatum [PI. 10, Figs. 7, 8] \\
\hline 34 & 53 & Phthanoperidinium sp. cf. $P$. resistente \\
\hline 85 & 105 & Phthanoperidinium comatum \\
\hline 105 & 51 & Phthanoperidinium echinatum \\
\hline 163 & 123 & Phthanoperidinium geminatum \\
\hline 147 & 111 & Phthanoperidinium sp. A [Pl. 10, Figs. 5, 6] \\
\hline 66 & 65 & Phthanoperidinium spp. \\
\hline 171 & 172 & Polysphaeridium sp. A [PI. 11, Fig. 12] \\
\hline 124 & 165 & Reticulatosphaera actinocoronata \\
\hline 97 & 73 & Rhizophagites of Wrenn and Kokinos, 1986 [PI. 10, Fig. 12] \\
\hline 39 & 8 & "Rhombodinium" glabrum \\
\hline
\end{tabular}

Table 1 (continued).

\begin{tabular}{|c|c|c|}
\hline $\begin{array}{c}\text { Table } \\
3 \mathrm{~A}\end{array}$ & $\begin{array}{c}\text { Table } \\
\text { 3B }\end{array}$ & Marine palynomorph species \\
\hline 29 & 5 & Rhombodinium? sp. A [P1. 1, Fig. 7] \\
\hline 3 & 1 & Rhombodinium? sp. B [Pl. 1, Fig. 9] \\
\hline 40 & 9 & Rhombodinium? sp. C [Pl. 1, Fig. 8] \\
\hline 49 & 103 & Samlandia chlamydophora $[\mathrm{Pl} .12$, Fig. 7] \\
\hline 129 & 89 & Selenopemphix armata [Pl. 7, Fig. 10] \\
\hline 87 & 129 & Selenopemphix nephroides \\
\hline 99 & 98 & Selenopemphix sp. 1 [Pl. 7, Figs. 1, 2] \\
\hline 164 & 124 & Selenopemphix? sp. 2 [Pl. 7, Fig. 3] \\
\hline 148 & 115 & Selenopemphix? sp. 3 [Pl. 7, Figs. 4, 8] \\
\hline 138 & 92 & Selenopemphix sp. 4 [Pl. 7, Fig. 13] \\
\hline 96 & 64 & Selenopemphix sp. 5 [PI. 7, Fig. 14] \\
\hline 16 & 156 & Spiniferites pseudofurcatus \\
\hline 11 & 155 & Spiniferites/Achomosphaera spp. \\
\hline 175 & 175 & Surculosphaeridium? sp. A [Pl. 11, Fig. 1] \\
\hline 118 & 86 & Svalbardella sp. cf. S. cooksoniae \\
\hline 168 & 135 & Svalbardella sp. 1 [PI. 2, Figs. 9, 10] \\
\hline 153 & 118 & Svalbardella? sp. 2 \\
\hline 8 & 112 & Systematophora ancyrea \\
\hline 43 & 18 & Systematophora sp. 1 [PI. 13, Fig. 1] \\
\hline 68 & 138 & Tectatodinium pellitum \\
\hline 48 & 61 & Tectatodinium sp. 1 [Pl. 13, Fig. 8] \\
\hline 122 & 78 & Thalassiphora delicata \\
\hline 169 & 152 & Thalassiphora fenestrata \\
\hline 9 & 126 & Thalassiphora pelagica [Pl. 9, Figs. 2, 3] \\
\hline 65 & 55 & Thalassiphora sp. A [PI. 9, Fig. 6] \\
\hline 108 & 85 & Thalassiphora sp. B [PI. 9, Figs. 7, 8] \\
\hline 165 & 125 & Thalassiphora sp. C [PI. 9, Fig. 4] \\
\hline 170 & 143 & Thalassiphora sp. D [PI. 9, Fig. 5] \\
\hline 27 & 23 & Wetzellella articulata \\
\hline 135 & 142 & Wetzellella symmetrica \\
\hline 70 & 41 & Wilsonidium tabulatum [PI. 2, Figs. 11, 12] \\
\hline
\end{tabular}

Note: reference to the location of these species can be found in Tables 3A (lowest occurrences) and 3B (highest occurrences) and in the plates (where applicable).

or sporadically have been omitted. Of those species that are considered to be stratigraphically useful, many occur sporadically in Hole 647A, or well within their established ranges. Analysis of additional samples will be needed to verify their distribution through Hole 647A. For this reason, no formal zonation is proposed here. Nevertheless, the occurrences of a number of species provide useful constraints upon the biostratigraphy of Hole $647 \mathrm{~A}$. These are discussed principally within the stratigraphic framework provided by calcareous nannofossils (Firth, this volume). Additional detailed information on selected species is given in a later section of this chapter ("Stratigraphic and Morphologic Notes on Selected Dinocyst Taxa," this volume) and is accompanied by a summary of stratigraphic ranges in Table 2.

\section{DINOCYST STRATIGRAPHY AND AGE}

\section{Lower Eocene, Nannofossil Zones NP11 through NP13}

(Samples 105-647A-71R-1, 40-43 cm, through $-66 \mathrm{R}-1,66-69 \mathrm{~cm}$; 695-637 mbsf)

\section{Dinoflagellates}

Adnatosphaeridium robustum (P1. 13, Fig. 3) occurs in the two lowest samples examined and is known from a number of lower Eocene localities. Apparently, this species is restricted to Zone NP12 in the Rockall Plateau (Brown and Downie, 1984) and thus has a slightly lower appearance (Zone NP11) within the lower Eocene in Hole 647A.

Rhombodinium? sp. B (Pl. 1, Fig. 9) is a new species occurring commonly in a single sample (Sample 105-647A-70R-4, 42$45 \mathrm{~cm}$ ). The species may be related to the Wetzeliella-Rhombodinium lineage that first appears in the early Eocene (Costa and Downie, 1979a; Bujak and Davies, 1983). 
Table 2. Stratigraphic occurrence of selected dinocyst taxa recorded from the Paleogene of Hole 647A and their corresponding ranges.

\begin{tabular}{|c|c|c|c|c|c|c|c|c|c|c|c|c|c|c|c|c|c|}
\hline \multirow[t]{2}{*}{ EPOCH } & PAL & & & $\mathbf{E}$ & 0 & C & 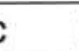 & $\mathbf{E}$ & $\mathbf{N}$ & & E & & $0 \mathrm{~L}$ I G & G 0 & C E & N E & MIO \\
\hline & U & \multicolumn{4}{|c|}{ L } & \multicolumn{4}{|c|}{ M } & \multicolumn{3}{|c|}{$\mathbf{U}$} & \multicolumn{2}{|l|}{ L } & \multicolumn{2}{|r|}{$\mathbf{U}$} & L \\
\hline CALCAREOUS NANNOFOSSIL ZONES (Martini, 1971) & $\mathrm{NP9}$ & NP10 & NP11 & 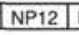 & NP13 & 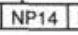 & NP15 & NP16 & NP17 & NP18 & \begin{tabular}{|l|l|l|l|l|} 
& NP19 \\
\end{tabular} & INP20 & \begin{tabular}{|l|l|l|} 
NP21 & NP22 \\
\end{tabular} & NP23 & NP24 & INP25 & NN \\
\hline \multicolumn{18}{|l|}{ DINOCYSTS from Hole 647A } \\
\hline \multirow{2}{*}{\multicolumn{18}{|c|}{$\begin{array}{l}\text { Adnatosphaeridium robustum } \\
\text { Alisocysta sp. cf. } \text { A. ornata }\end{array}$}} \\
\hline & & & & & & & & & & & & & & & & & \\
\hline \multirow{2}{*}{\multicolumn{18}{|c|}{$\begin{array}{l}\text { Alisocysta sp. } 1 \\
\text { Areosphaeridium arcuatum }\end{array}$}} \\
\hline & & & & & & & & & & & & & & & & & \\
\hline \multirow{2}{*}{\multicolumn{18}{|c|}{$\begin{array}{l}\text { Areosphaeridium diktyoplokus } \\
\text { Areosphaeridium pectiniforme } \\
\text { Chiropteridium lobospinosum }\end{array}$}} \\
\hline & & & & & & & & & & & & & & & & & \\
\hline \\
\hline \multirow{2}{*}{\multicolumn{18}{|c|}{$\begin{array}{l}\text { Cordosphaeridium funiculatum } \\
\text { C. funiculatum sensu Williams and Bujak, 1977b } \\
\text { Cordosphaeridium sp. cf. C. funiculatum }\end{array}$}} \\
\hline & & & & & & & & & & & & & & & & & \\
\hline \multirow{2}{*}{\multicolumn{18}{|c|}{$\begin{array}{l}\text { Corrudinium incompositum } \\
\text { Corrudinium sp. } 2\end{array}$}} \\
\hline & & & & & & & & & & & & & & & & & \\
\hline \multirow{2}{*}{$\begin{array}{l}\text { Deflandrea leptodermata } \\
\text { Dinocyst sp. D } \\
\text { Distatodinium paradoxum sensu Gocht, } 1969\end{array}$} & & & & $=$ & & 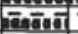 & - & & & & & & & & & & \\
\hline & & & & & & & & & & Imin & nimini & & 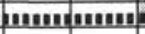 & & & & \\
\hline \multirow{3}{*}{$\begin{array}{l}\text { Dracodinium? condylos } \\
\text { Dracodinium? sp. cf. D.? condylos } \\
\text { Duosphaeridium sp. cf. D. rugosum } \\
\text { Eatonicysta ursulae }\end{array}$} & & & & & & $=-$ & & & & & & & & & & & \\
\hline & & & $\ln \overline{1}$ & $=-$ & & & & & & & & & & & & & \\
\hline & & & & & & 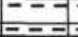 & $=$ & & & & & & & & & & \\
\hline \multirow{3}{*}{$\begin{array}{l}\text { Elytrocysta sp. of Goodman and Ford, } 1983 \\
\text { Elytrocysta sp. A } \\
\text { Gelatia inflata } \\
\text { Hemiplacophora semilunifera }\end{array}$} & & . & & & & ---1 & & & & ment & these & & & & & & \\
\hline & & & & & & & & & & & & & & & & & \\
\hline & & & & & & & & & & IIIII) & $=-$ & & & & & & \\
\hline \multirow{4}{*}{$\begin{array}{l}\text { Heteraulacacysta porosa } \\
\text { Heteraulacacysta sp. A } \\
\text { Histiocysta spp. of Goodman and Ford, } 1983 \\
\text { Homotryblium sp. A } \\
\end{array}$} & & & & & & & & & & & & & & & & & \\
\hline & & & & & & & & IIIIII & & & & & & & & & \\
\hline & & & & & & - & $=$ & & & & & & & & & IIIII & \\
\hline & & & & & & & & & & & & & & & & & \\
\hline \multicolumn{18}{|l|}{$\begin{array}{l}\text { Impagidinium? pallidum } \\
\text { Impagidinium velorum } \\
\text { Kisselovia coleothrypta }\end{array}$} \\
\hline Kisselovia coleothrypta & & & & & & & & & & & & & & ב & & & \\
\hline Kisselovia crassoramosa & & & & & & & & & & & & & & ini: & & & \\
\hline \multirow{3}{*}{$\begin{array}{l}\text { Kisselovia edwardsii sensu Caro, } 1973 \\
\text { Litosphaeridium sp. A } \\
\text { Litosphaeridium? sp. B } \\
\text { Phthanoperidinium? brooksii }\end{array}$} & & & & mane & & timini & 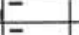 & & & & & & & & & & \\
\hline & & & & & & & & & & & & & & & & & \\
\hline & & & & & & & & & & & & & & & & & \\
\hline Phthanoperidinium comatum & & & & & & & & & & & & & & E & & & \\
\hline "Rhombodinium" glabrum & & & & & & & & & nasum & Imen! & уаним & Himin & & & & & \\
\hline Rhombodinium? sp. A & & & & & & & & & & & & & & & & & \\
\hline \begin{tabular}{|l} 
Rhombodinium? sp. B \\
Rhombodinium? sp. C
\end{tabular} & & & $=$ & & & & & & & & & & & & & & \\
\hline $\begin{array}{l}\text { Rhombodinium? sp. C } \\
\text { Samlandia chlamydophora }\end{array}$ & & & |IIIII & & & & & & & & & & & & & & \\
\hline Svalbardella & & & & IIIIII & mint & 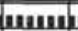 & Imunit & min & & & & & & & & & \\
\hline Svalbardella sp. cf. $S$. cooksoniae & & & & & & & & & & & & & & & & & \\
\hline Svalbardella sp. 1 & & & & & & & & & & & & & & & & & \\
\hline $\begin{array}{l}\text { Svalbardella? sp. } 2 \text {. } \\
\text { Thalassiphora pelagica }\end{array}$ & & & & & & & & & & & & & & $=$ & & & \\
\hline $\begin{array}{l}\text { Thalassiphora pelagica } \\
\text { Wetzeliella symmetrica }\end{array}$ & & & Henur! & timint & & & & min! & & & & & & & & & \\
\hline
\end{tabular}

Note: Selected dinocyst taxa occurring in Hole 647A (stippled lines) are calibrated to Martini's (1971) standard calcareous nannofossil zonation (from Firth, this volume). Their corresponding ranges (solid lines) are based on the literature and as discussed in this chapter. Broken lines indicate uncertain ranges, and intrazonal ranges are approximate. The time scale of Berggren et al. (1985) is used.

The presence of Dracodinium? condylos in Sample 105-647A$69 \mathrm{R}, \mathrm{CC}$ indicates a stratigraphic position no lower than upper Zone NP11, and the assignment of this sample to Zones NP11 or lower NP12 in Hole 647A (Firth, this volume) agrees with its range of upper Zones NP11 to NP14 from the Rockall Plateau (Brown and Downie, 1984; Costa and Downie, 1979b).

The lowest occurrence of Kisselovia coleothrypta (Pl. 1, Fig. 1) in Sample 105-647A-68R-1, 129-132 cm, assignable to Zone NP12 (Firth, this volume), is comparable to its lowest occurrence in Zone NP12 sediments from the Rockall Plateau, Site 404 (Costa and Downie, 1979b). Likewise, the lowest occurrence of Kisselovia edwardsii sensu Caro, 1973 (Pl. 1, Fig. 3) in Sample 105-647A-66R-2, 29-33 cm (assignable to Zone NP13; Firth, this volume) compares with its occurrence in a single sample from Zone NP13 in DSDP Hole 553A on the Rockall Plateau (Brown and Downie, 1984).

"Rhombodinium" glabrum (Pl. 1, Fig. 8) occurs rarely in a single sample (105-647A-67R-4, 23-26 cm), assignable to Zone NP12 (Firth, this volume), and was similarly recorded from a single sample within Zone NP12 in DSDP Hole 548A, Goban Spur (Brown and Downie, 1985).
Samlandia chlamydophora (Pl. 12, Fig. 7) has a lowest occurrence in Sample 105-647A-66R-2, 29-33 cm, and can be assigned to Zone NP13 (Firth, this volume). This is slightly higher than lowest occurrences recorded elsewhere (e.g., Zone NP12 sediments in the Rockall Plateau, southern Europe and eastern U.S.).

Dinopterigium cladoides sensu Morgenroth, 1966 has a lowest occurrence in Sample 105-647A-67R-2, 28-31 cm, assigned to upper Zone NP12 (Firth, this volume). This compares well with the lowest occurrence of this species in southern England (Bujak et al., 1980, Zone NP12 using correlation of Aubrey, 1985 ) and with its range base given as upper Zone NP12 in Williams and Bujak (1985; see also discussion of this species in Head et al., c, this volume).

\section{Other Microfossils}

Sample 105-647A-71R-2, $41 \mathrm{~cm}$, is the lowest sample found containing age-diagnostic nannofossils and has been placed in nannofossil Zone NP11 (middle lower Eocene) by Firth (this volume). The lowest sample assigned to Zone NP12 is Sample $105-647 \mathrm{~A}-68 \mathrm{R}-4,36-38 \mathrm{~cm}$ (Firth, this volume), or slightly lower 
at Sample 105-647A-69R, CC (Firth, in Srivastava, Arthur, et al., 1987, p. 701).

Sample 105-647A-66R-1, 52-54 cm, is the highest sample containing early Eocene nannofossils (assigned to Zone NP13; Firth, this volume), and above this is an interval barren of calcareous microfossils that contains the lower/middle Eocene boundary.

\section{Upper Lower? to Lower Middle Eocene, Nannofossil Zones NP13? through NP15?}

(Samples 105-647A-66R-1, 15-18 cm, through $-63 \mathrm{R}-1,105-108 \mathrm{~cm}$; 652-609 mbsf)

Although barren of nannofossils and planktonic foraminifers, this interval yields moderately to well-preserved dinocyst assemblages. A hiatus may occur within this interval of Hole $647 \mathrm{~A}$, but unfortunately, a regional unconformity developed in the upper lower to lower middle Eocene of DSDP sites from the Rockall Plateau and Goban Spur has removed much opportunity to compare dinoflagellate ranges between these sites and Hole 647A. On the Rockall Plateau, the most complete dinoflagellate stratigraphy is from DSDP Site 406 , where Zone NP18 sediments overlie those assigned to Zone NP14 (Costa and Downie, 1979b; Müller, 1979), while Holes 553A and 552, investigated by Brown and Downie (1984), also have a lower middle Eocene hiatus and are barren of dinoflagellates above sediments assigned to Zone NP13 (Brown and Downie, 1984; Backman, 1984). On the Goban Spur, sediments of Zone NP15 overlie those of Zone NP12, but samples from virtually all the middle to upper Eocene were barren of dinoflagellates (Brown and Downie, 1985; Müller, 1985).

\section{Dinoflagellates}

Although many of the dinocyst species recorded have poorly established ranges, or have occurrences that are not critical for refining the age of this interval, several species occurrences nevertheless provide support for an upper lower to lower middle age, as inferred from nannofossil biostratigraphy above and below this interval. These species include the lowest occurrence of Areosphaeridium diktyoplokus (Pl. 13, Figs. 5,9) in Sample 105-647A-63R-1, 139-142 cm, which indicates an equivalence to Zone NP13 or higher for this sample, and the highest occurrence of Eatonicysta ursulae (Pl. 9, Fig. 9) in Sample 105-647A$65 \mathrm{R}-1,117-121 \mathrm{~cm}$, which indicates an equivalence to middle Zone NP16 or lower for this sample. Perhaps the most significant biostratigraphic event within this interval is the highest occurrence of Kisselovia edwardsii sensu Caro, 1973 in Sample $105-647$ A-64R-3, 88-91 cm. This species is restricted to sediments of putative Cuisian age in Labrador Shelf and North Sea wells examined by Ioakim (1979) and was assigned a provisional range in northwestern Europe of Zones NP12 through NP14 by Manum (1980). Sample 105-647A-64R-3, 88-91 cm, thus can be assigned to Zone NP14 or lower (lower Eocene or lowermost middle Eocene), based on the tentative range of $K$. edwardsii sensu Caro, 1973.

Other dinocyst events that in the future may prove stratigraphically useful within this interval include the first appearance (FA) of Hystrichosphaeropsis sp. B (Pl. 2, Figs. 1 through 3) and Thalassiphora sp. B (Pl. 9, Figs. 7,8), in Sample 105647A-64R-1, CC; FA of Elytrocysta sp. of Goodman and Ford, 1979 in Sample 105-647A-63R-1, 139-142 cm, and possible FA of Histiocysta sp. of Goodman and Ford, 1979 (Pl. 3, Figs. 5 through 9) in Sample 105-647A-63R-1, 105-109 cm.

Last appearances (LAs) that may have potential biostratigraphic significance include the LA of Hystrichokolpoma globulum Michoux, 1985 (PI. 12, Figs. 9,10) in Sample 105-647A$65 \mathrm{R}-1,117-121 \mathrm{~cm}$, and the LA of Ceratiopsis? sp. A (Pl. 12, Fig. 13), which is discussed below.
The position of a hiatus within this interval (as indicated by the sedimentation-rate curve for Hole 647A) was not clearly determined by the preliminary dinocyst stratigraphy, although we suggest two possible placements; one (the lower) located between Samples 105-647A-66R-1, 66-69 cm, and -65R-1, 117-121 $\mathrm{cm}$, and the other (the higher) between Samples 105-647A-64-3, $88-91 \mathrm{~cm}$, and $-63 \mathrm{R}-1,139-142 \mathrm{~cm}$. The lower possible location is indicated by an influx of species in Sample 105-647A-65R-1, $117-121 \mathrm{~cm}$, which occurs above two low-yielding samples (Samples 105-647A-66R-1, 15-18 cm, and -65R, CC), suggesting a hiatus within the interval between Samples 105-647A-65R-1, 117$121 \mathrm{~cm}$, and $-66 \mathrm{R}-1,66-69 \mathrm{~cm}$. The higher possible position (i.e., between Samples 105-647A-64-3, 88-91 cm, and -63R-1, $139-142 \mathrm{~cm}$ ) is given by the highest occurrence of both Ceratiopsis? sp. A (P1. 12, Fig. 13) and Kisselovia edwardsii sensu Caro, 1973 (Pl. 1, Fig. 3) in Sample 105-647A-64R-3, 88-91 cm, and the lowest occurrences of Elytrocysta sp. of Goodman and Ford, 1979 (PI. 3, Figs. 1 through 3) and Areosphaeridium diktyoplokus in Sample 105-647A-63R-1, 139-142 cm. Support for this possibility is that Kisselovia edwardsii sensu Caro, 1973 and Ceratiopsis sp. A (which may be conspecific with Deflandrea sp. 1 of Ioakim, 1979, although it is somewhat smaller) apparently have simultaneous last occurrences in Hole 647A. In both the Freydis B. 87 and Bjarni H. 81 wells on the Labrador Shelf, Deflandrea sp. 1 of Ioakim, 1979 has a slightly higher range top (into the putative Lutetian) than Kisselovia edwardsii sensu Caro, 1973 (which is restricted to the putative Cuisian). The range top of Ceratiopsis? sp. A, if conspecific with Deflandrea sp. 1 of Ioakim, 1979, thus may be truncated in Hole 647A. Furthermore, the lowest occurrence of $A$. diktyoplokus in Sample 105-647A-63R-1, 139-142 cm (which is just one core below sediments assigned to Zone NP15; Firth, this volume), may represent a slight truncation of its range base, since elsewhere this species has a range base within Zone NP13 (e.g., upper Zone NP13 at DSDP Site 405, Rockall Plateau; Costa and Downie, 1979b).

To summarize the dinocyst biostratigraphy for this interval: the LA of E. ursulae in Sample 105-647A-65R-1, 117-121 cm, places this sample no higher than middle Zone NP16; the LA of $K$. edwardsii sensu Caro, 1973 in Sample 105-647A-64R-3, 88$91 \mathrm{~cm}$, tentatively places this sample no higher than Zone NP14; and the FA of Areosphaeridium diktyoplokus in Sample 105647A-63R-1, 139-142 cm, places this sample no lower than Zone NP13. Two possible locations for a hiatus are tentatively suggested: (1) the lower, occurring between Samples 105-647A-66R-1, 66-69 cm, and $-65 \mathrm{R}-1,117-121 \mathrm{~cm}$, and based on an influx of species; and (2) the higher, occurring between Samples 105647A-64R-3, 88-91 cm, and -63R-1, 139-142 cm, and based on the suspected range truncation of several dinocyst species.

\section{Other Microfossils}

The interval between Samples 105-647A-63R-1, 36-38 cm (assigned to Zone $\mathrm{CP} 13 \mathrm{~b} \equiv \mathrm{NP} 15$ ) and $-66 \mathrm{R}-1,52-54 \mathrm{~cm}$ (assigned to Zone CP11 $\equiv$ NP13) is barren of nannofossils (Firth, this volume) and planktonic foraminifers. This interval contains the lower/middle Eocene boundary, and the sedimentation-rate curve for Hole 647A (Kaminski et al., this volume) suggests that the lower middle Eocene and possibly the uppermost lower Eocene are missing from this interval.

\section{Upper Middle and Upper Eocene, Nannofossil Zones NP15 through NP20}

(Samples 105-647A-62R-6, 22-25 cm through -32R, CC; 606-300 mbsf)

\section{Dinoflagellates}

Phthanoperidinium comatum has a lowest occurrence in Sample 105-647A-61R, CC (Zone NP15, Firth, this volume). This is 
somewhat younger than the earliest record known for $P$. comatum of upper lower Eocene from the Rockall Plateau (Zone NP13, Costa and Downie, 1979b, correlated from Müller, 1979).

Phthanoperidinium? brooksii (Pl. 10, Figs. 1,2) was recorded from a single sample (105-647A-59R, CC, assigned to Zone NP15, Firth, this volume); this species has been reported previously only from approximately coeval middle Eocene sediments (probable Zone NP15) of the eastern U.S. continental slope (Edwards and Bebout, 1981).

Heteraulacacysta sp. A (Pl. 8, Fig. 15), occurring in a single sample (105-647A-53R-4, 121-125 cm, assignable to Zone NP16, Firth, this volume), may be conspecific with a specimen illustrated as Heteraulacacysta porosa in Edwards (1984) from the middle Eocene of Virginia (correlated to Zone CP14a $\equiv$ NP16, from DiMarzio, 1984).

Corrudinium incompositum (P1. 3, Fig. 15) has an FA within Zone NP16 in Hole 647A (Firth, this volume), has an LA in Sample 105-647A-51R, CC, and occurs questionably down to Sample 105-647A-52R-4, 25-28 cm. Elsewhere, this species has a first occurrence in probable Zones NP15 (offshore eastern U.S., Edwards and Bebout, 1981) or NP16 (S. England, in Bujak et al., 1980; Aubry, 1985), which correlates precisely with its FA in Hole $647 \mathrm{~A}$.

Hemiplacophora semilunifera (Pl. 5, Figs. 9,10) occurs in Samples 105-647A-35R, CC and -36R, CC from the upper Eocene (Zone NP19, Firth, this volume) of Hole 647A. Present and previous records suggest that this species may be a useful indicator of middle to upper Eocene sediments. Likewise, Heteraulacacysta porosa (Pl. 8, Fig. 8), occurring in Samples 105647A-35R, CC through -33R-1, 91-94 cm, just below the Eocene/Oligocene boundary in Hole $647 \mathrm{~A}$, is probably restricted to upper middle and upper Eocene sediments elsewhere.

\section{Other Microfossils}

A continuous record of sedimentation is preserved throughout this interval and across the Eocene/Oligocene boundary, with the exception of an unconformity or period of reduced sedimentation rate between Zones NP16 and NP17 (at about 455 mbsf) that may have resulted in the absence or condensing of the lower part of Zone NP17 and possibly some upper Zone NP16 (Firth, this volume). Sample 105-647A-63R-1, 36-38 cm (assigned to Zone $\mathrm{CP} 13 \mathrm{~b} \equiv \mathrm{NP} 15$ ) contains the oldest recovered nannofossil assemblage from this interval (Firth, this volume), while the oldest planktonic foraminiferal sample (105-647A$62 \mathrm{R}-6,22-25 \mathrm{~cm}$ ) was assigned to Zone P12, indicating an age no older than $46 \mathrm{Ma}$ (middle middle Eocene) for this sample (Srivastava, Arthur, et al., 1987).

The middle/upper Eocene (Zone NP17/18) boundary was tentatively placed between Samples $105-647$ A-46R-4, 101-103 cm (NP17) and -46R-3, 33-35 cm (FA Chiasmolithus oamaruensis Zone NP18), at an estimated depth of $440 \mathrm{mbsf}$, based on nannofossils (Firth, this volume).

The Eocene/Oligocene boundary was placed between Samples 105-647A-30R-7, 17-19 cm, and -30R-7, $48 \mathrm{~cm}$, based on the highest occurrence (in Sample 105-647A-30R-7, $48 \mathrm{~cm}$ ) of the nannofossil Discoaster barbadiensis (Firth, this volume). Planktonic foraminiferal biostratigraphy, in close agreement with the nannofossil biostratigraphy, places this boundary at the base of Core 105-647A-30R, just above the last occurrences of Globigerina linaperta (in Sample 105-647A-31R-2, 34-37 cm) and Turborotalia cerroazulensis (in Sample 105-647A-31R, CC) (Srivastava et al., 1987).

\section{Oligocene, Nannofossil Zones NP21 through NP24}

Samples 105-647A-30R-3, 100-104 cm, through -15R, CC; 283-139 mbsf)

\section{Dinoflagellates}

The occurrences of a number of dinoflagellate species in the Oligocene of Hole 647A fall within, or are approximately coincident with, their ranges established elsewhere and support the biostratigraphy provided by nannofossils for this hole (Firth, this volume). These species include the following: Kisselovia coleothrypta (LA in Sample 105-647A-28-4, 88-91 cm, range top in lower Zone NP23, lower Oligocene), Cordosphaeridium funiculatum (LA in Sample 105-647A-28R-4, 88-91 cm; range top in lower Oligocene), Samlandia chlamydophora (LA in Sample 105-647A-24R-2, 142-145 cm; range top in lower Zone NP23, lower Oligocene), Elytrocysta sp. of Goodman and Ford, 1983 (LA in Sample 105-647A-24R-2, 142-145 cm, range top in lower? Oligocene), Phthanoperidinium comatum (LA in Sample 105647 A-24R-2, 142-145 cm, range top in lower Zone NP23, lower Oligocene), Corrudinium incompositum (LA in Sample 105647A-24R-2, 142-145 cm, range top in lower Zone NP23, lower Oligocene), Histiocysta spp. of Goodman and Ford, 1983 (LA in Sample 105-647A-22R, CC, range top in the lower? upper Oligocene), Distatodinium paradoxum sensu Gocht (1969, Pl. 7, Figs. 5,6) (Pl. 5, Fig. 7) (single occurrence in Sample 105647A-22R, CC, range top in upper Oligocene), Areosphaeridium arcuatum (LA represented by a single specimen in Sample 105-647A-21R, CC, range top in lower Zone NP23, lower Oligocene), Thalassiphora pelagica (LA in Sample 105-647A-19R, CC, range top in the upper Oligocene), Areosphaeridium pectiniforme (LA in Sample 105-647A-19R, CC, range top in the lower upper Oligocene), Wetzeliella symmetrica (LA in Sample 105647A-17R, CC, range top in the lower? upper Oligocene), Gelatia inflata (Pl. 4, Fig. 5) (occurring in Samples 105-647A-24R-2, $142-145 \mathrm{~cm}$, through -16R, CC, range of upper Eocene to upper Oligocene), Chiropteridium mespilanum (Pl. 5, Figs. 3,6) (occurring in Samples 15-647A-22R, CC through -15R, CC, range of upper Eocene to upper Oligocene or lowermost Miocene).

In addition, several species that extend into or occur within the Oligocene of Hole $647 \mathrm{~A}$ and that presently have unknown or uncertain global ranges may prove useful stratigraphic indicators. These include the following: Phelodinium sp. 4 ( $\mathrm{Pl} .7$, Figs. 6, 7) (occurring in Samples 105-647A-33R-1, 91-94 cm, through -16R, CC), Invertocysta? sp. (Pl. 4, Figs. 3,4) (occurring in Samples 105-647A-25R, CC? through -15R, CC), Impagidinium? sp. D (Pl. 8, Figs. 9 through 11) (occurring in Samples 105-647A-22R, CC through -19R, CC) and Phelodinium? sp. 5 (Pl. 8, Fig. 12) (occurring in Samples 105-647A-22R, CC through $-16 \mathrm{R}, \mathrm{CC})$.

The lowest occurrences of Impagidinium velorum (Pl. 10, Fig. 11) (Sample 105-647A-28R-4, 88-91 cm), Gelatia inflata (in Sample 105-647A-24R-2, 142-145 cm), and Chiropteridium mespilanum (in Sample 105-647A-22R, CC) within the Oligocene of Hole 647A may provide useful local stratigraphic datums, although these are somewhat higher than their lowest occurrences recorded from certain other localities.

\section{Other Microfossils}

An apparently continuous sedimentary succession extends across the Eocene/Oligocene boundary, through the lower Oligocene and into the lower upper Oligocene. This is overlain by a condensed Miocene sequence. Firth (this volume) reported the highest Oligocene nannofossil assemblage in Sample 105-647A$15 \mathrm{R}-1,68-70 \mathrm{~cm}$, which he assigned to Zone NP24, of latest early or early late Oligocene age. Diatom stratigraphy suggests that Core $105-647 \mathrm{~A}-15 \mathrm{R}$ is equivalent to the lowermost part of nannofossil Zone NP24 and thus is of latest early Oligocene age (Baldauf and Monjanel, this volume). Alternatively, the recog- 
nition of planktonic foraminiferal Zones P21b/P22 in Samples 105-647A-15R, CC through -19R, CC (Srivastava, Arthur, et al., 1987) supports a late Oligocene age for these sediments. Sample 105-647A-30R-7, 17-19 cm, contains the lowest reported Oligocene nannofossil assemblage and has been assigned to Zone NP21, based on the presence of nannofossils Ericsonia formosa and absence of Discoaster barbadiensis (Firth, this volume).

\section{Miocene}

(Samples 105-647A-14R-3, 32-34 cm, through

$-13 \mathrm{R}-5,8-13 \mathrm{~cm} ; 129-122 \mathrm{mbsf})$

\section{Dinoflagellates}

Three samples (105-647A-13R-5, 8-13 cm; -14R-2, 145-147 $\mathrm{cm}$; and $-14 \mathrm{R}-3,32-34 \mathrm{~cm}$ ) from the Miocene of Hole $647 \mathrm{~A}$ were processed for palynomorphs. Only carbonized organic debris was recovered from these samples, suggesting oxidation of organic material during sedimentation or diagenesis.

\section{Other Microfossils}

Miocene sediments of Hole 647A are restricted to Cores 105$647 \mathrm{~A}-13 \mathrm{R}$ and $-14 \mathrm{R}$ and are barren of calcareous microfossils, except for the upper part of Core 105-647A-13R, which was assigned to the upper Miocene Zone NN11 (Srivastava, Arthur, et al., 1987). Diatoms and radiolarians occur in the lower part of Core 105-647A-13R and in Core 105-647A-14R and indicate a lower Miocene age (Srivastava, Arthur, et al., 1987; Lazarus, this volume).

\section{DINOFLAGELLATE PALEOECOLOGY AND PALEOCEANOGRAPHY}

Today, marine dinoflagellates that produce organic-walled cysts principally inhabit shelf environments. In contrast, no species known to occupy a fully oceanic habitat (e.g., Ceratium spp.) have been found to produce organic-walled cysts. Despite this, dinoflagellate cyst assemblages have been reported from sediments at mid-oceanic sites (Harland, 1983). This inconsistency may partly reflect the undoubted inadequacies of present knowledge regarding the biology of many oceanic dinoflagellates. Alternatively, these cyst assemblages were not the products of self-sustaining in-situ oceanic dinoflagellate communities, but were produced either by temporary influxes (or blooms) of thecae transported by surface currents from a neritic environment or were transported as cysts from the shelf and shelf slope by bottom currents. Allochthonous components of dinoflagellate cyst assemblages were recognized from deep-water Miocene sediments at Site 646, Labrador Sea (Head et al., b, this volume) and in the Gulf of Mexico (Wrenn and Kokinos, 1986). In view of the deep-water location of Site 647 , possibly many dinoflagellate cysts recorded in this study are also allochthonous to some degree. Certain paleoenvironmental interpretations thus have been made with reservations, although general conclusions may be drawn. These are given below and compared with interpretations based upon other microfossil groups (from Srivastava, Arthur, et al., 1987).

\section{Lower Eocene, Nannofossil Zones NP11 through NP13}

(Samples 105-647A-71R-1, 40-43 cm, through $-66 \mathrm{R}-1,66-69 \mathrm{~cm}$; 695-637 mbsf)

\section{Dinoflagellates}

The high proportion of dinoflagellate cysts to terrigenous organic material including spores and pollen, together with the consistent presence of Impagidinium spp. and low-to-moderate abundances of proximate cysts during this interval, collectively suggest an oceanic environment with a notable influence from the (outer?) shelf. This is supported by the scarcity of Wetzeliella and Apectodinium, species that may be common or characteristic components of low-salinity estuarine and inner-shelf environments (Downie et al., 1971; Goodman, 1979; Chateauneuf, 1980; Islam, 1984; Brown and Downie, 1984; Rauscher and Schuler, 1988; Mao and Norris, 1988), although related genera (Kisselovia, Rhombodinium, and Dracodinium?) are common in some samples and persistent up to Sample 105647A-64R-3, 88-91 cm. Islam (1984) found that Dracodinium favored more-saline, offshore, and deeper water environments, compared with other Wetzeliellaceae. Likewise, Goodman (1979) found that Kisselovia (a single species recorded) was associated with an offshore trend in lower Eocene sediments of Maryland, U.S. Spiniferites and Achomosphaera spp., which are well represented in this interval, are abundant on the open-marine shelf (Wall and Dale, 1973) and are a common component of Eocene open-marine environments (Downie et al., 1971; Islam, 1984). Of particular interest is the occurrence of Dinocyst? sp. A. (Pl. 13, Fig. 11). This species does not appear to have been previously reported in the literature, and in view of its pigmented wall, might be related to the Protoperidineaceae. The abundance of this species (more than $80 \%$ of the total dinoflagellate count in some samples) may represent unusual environmental conditions during this time at Site 647. Relative abundances of species were found to fluctuate considerably from sample to sample, even between samples from the same core (e.g., Cores 105-647A-66R, -67R, and -68R). Similar variations of dominant species were observed for lower and middle Eocene dinocyst assemblages from the Rockall Plateau (Costa and Downie, 1979b; Brown and Downie, 1984) and these presumably reflect fluctuations in water-mass properties at both localities. Lower Eocene dinocyst assemblages from Sample 105-647A-69R, CC and above in Hole 647A are comparable with coeval assemblages from the Rockall Plateau (Costa and Downie, 1979b), although Polysphaeridium zoharyi, considered a nearshore, warm-water indicator and reported to dominate a few samples at DSDP Sites 404 and 405, Rockall Plateau, (Costa and Downie, 1979b, p. 514) and DSDP Site 552 (Brown and Downie, 1984), was not recovered from Hole 647A. The absence of $P$. zoharyi, if not a sampling artifact, may suggest either (1) that Site 647 was exposed to the influence of cooler water during the Zone NP12 interval than DSDP Sites 404, 405 and 552 or (2) that Site 647 occupied a more offshore position. Williams and Bujak (1977a) found that Polysphaeridium zoharyi was absent from Labrador Shelf wells and had lowest occurrences in the upper Eocene and upper lower Eocene of the Scotian Shelf and Grand Banks, respectively.

\section{Other Microfossils}

Paleoenvironmental interpretations drawn from dinocyst assemblages are consistent with those provided by other microfossil groups (Srivastava, Arthur, et al., 1987; Firth, this volume). Both planktonic foraminiferal and nannofossil assemblages indicate warm-to-temperate water conditions for the lower Eocene. Nannofossil assemblages also contain moderate numbers of shelf species that, if not redeposited, may reflect greater proximity to the shelf edges during the early Eocene than in later time. Estimates based on a sedimentary backstripping method indicate a water depth of 1700 to $2000 \mathrm{~m}$ for basal sediments in Hole 647A, and benthic foraminiferal assemblages from these sediments support a bathyal setting (Kaminski, Gradstein, and Berggren, this volume; also references therein for a description of the backstripping method). 
Upper lower? to upper Eocene, Nannofossil Zones NP13? through NP20

(Samples 105-647A-66R-1, 15-18 cm, through -32R, CC; 652-300 mbsf)

\section{Dinoflagellates}

The continued persistence of Impagidinium spp. and low proportions of spores and pollen (mainly bisaccates) through this interval indicate open-marine conditions, as for the lower Eocene. However, the scarce and sporadic occurrences of Wetzeliellaceae specimens from Sample 105-647A-63R, CC and above may be a function of the more fully oceanic setting of Site 647 by middle Eocene time. As for the lower Eocene sediments, species occur sporadically and with variable abundances within this interval. Many assemblages are also characterized by preservational variability between constituent specimens, suggesting their transport from various different environments, and presumably originating from the shelf and shelf slope. A comparable feature was noted by Costa and Downie (1979b) for middle Eocene assemblages from Site 406, Rockall Plateau, although they found coeval assemblages from Site 405, which is more proximal to the shelf than Site 406 , to have excellent preservation. Middle to upper Eocene dinocyst assemblages from Site 647 are similar to those from the eastern North Atlantic and northwestern Europe, but the common presence of Histiocysta sp. of Goodman and Ford (1983) and Elytrocysta sp. of Goodman and Ford (1983) in many samples also suggests some affinity with assemblages recorded from the Norwegian-Greenland Sea, offshore eastern U.S.A., southwestern Atlantic, and New Zealand.

The common presence of Alisocysta sp. cf. A. ornata in Samples 105-647A-63R, CC and -59R, CC; of Alisocysta sp. 1 in Sample 105-647A-65R-1, 117-121 cm; and of Hemiplacophora semilunifera in Sample 105-647A-35R, CC have uncertain significance with respect to dinocyst provinciality. The common presence of Phthanoperidinium? brooksii in Sample 105-647A-59R, CC, however, suggests affinities with the western North Atlantic for this sample. Many species in this interval do not appear to have been described elsewhere and may be endemic to the Labrador Sea.

\section{Other Microfossils}

Middle and upper Eocene planktonic foraminifers in Hole $647 \mathrm{~A}$ represent temperate water-mass assemblages, with tropical elements occurring at occasional horizons (e.g., Hantkenina in Samples 105-647A-39R, CC and -50R, CC). Samples 105-647A$39 \mathrm{R}, \mathrm{CC}$ and $-50 \mathrm{R}, \mathrm{CC}$, were processed for dinocysts, but interestingly, do not contain known tropical dinocyst species. Nannofossil assemblages contain common cool-water indicators and low numbers of discoasters, which are warm-water indicators. High nannofossil diversity in the middle Eocene, becomes reduced in the upper Eocene, and assemblages indicate that warmer temperatures in the early middle Eocene gave way to more-temperate conditions through the rest of the middle Eocene (Firth, this volume).

\section{Oligocene, Nannofossil Zones NP21 through NP24}

(Samples 105-647A-30R-3, 100-104 cm, through -15R, CC; 283-139 mbsf)

\section{Dinoflagellates}

An abrupt change was not clearly identified in the taxonomic composition of dinoflagellate assemblages across the Eocene/Oligocene boundary in Hole 647A. Rather, changes seem to occur progressively (within the sampling limits of this study) into the Oligocene.
Oligocene assemblages have a continued oceanic aspect, with low abundances of terrigenous organic components. Dinocyst assemblages include a cosmopolitan component (including Chiropteridium spp., Systematophora ancyrea) together with North Pacific/Arctic (Gelatia inflata, Impagidinium velorum, and rare Impagidinium pallidum) and Norwegian-Greenland Sea (rare Svalbardella spp.) components. Histiocysta sp. of Goodman and Ford (1983) and Elytrocysta sp. of Goodman and Ford (1983) have a continued common presence in the lower Oligocene (up to Sample 105-647A-24R-2, 142-145 cm), perhaps also suggesting affinities with the Norwegian-Greenland Sea. In addition, a number of previously undescribed species (e.g., Dinocyst sp. 3 and Invertocysta sp. 3) and protoperidineacean species (Phelodinium and Selenopemphix spp.) occur in the upper Eocene and Oligocene. Warm-water species, such as Tuberculodinium vancampoae and Polysphaeridium zoharyi were not recorded, although the presence of Polysphaeridium sp. A in two samples (dominant in Sample 105-647A-17R, CC) possibly indicates infrequent warm-water incursions. In contrast, the presence of the high-latitude species Gelatia inflata, Impagidinium velorum, Impagidinium pallidum, and Svalbardella spp. suggests cool-water conditions in which arctic and North Atlantic surface-water masses possibly were mixed. The protoperidineacean component of upper Eocene and Oligocene assemblages at Site 647 may be paleoecologically significant, since abundant cysts of this group have been particularly attributed elsewhere to high nutrient influx caused, for example, by oceanic upwelling or high river discharge (see Head et al., a, this volume, and references therein). Many protoperidineacean species are also associated with inner neritic environments during the Neogene to Holocene (Harland, 1983; Wrenn and Kokinos, 1986), although our preliminary observations of the Paleogene palynomorph assemblages for Site 647 do not suggest a significant increase in shelf-originated organic debris. Thus, we suggest that increased availability of nutrients, perhaps related to increased upwelling or the effects of water-mass mixing, were responsible for the diverse representation of protoperidineacean species during the late Eocene and Oligocene at Site 647. Some support for this is given by increases in abundance of both siliceous microfossils, including diatoms and radiolarians, and of total organic carbon for the Oligocene interval of Site 647, suggesting increased surface-water productivity during this time (Srivastava, Arthur, et al., 1987).

\section{Other Microfossils}

Planktonic foraminiferal assemblages for the Oligocene of Hole 647A suggest cool-temperate to temperate water masses during the Oligocene (Srivastava, Arthur, et al., 1987). Low-diversity nannofossil assemblages, with the common occurrence of the cool-water indicator Isthmolithus recurvatus in the lowermost Oligocene, and scarcity of sphenoliths and discoasters, also indicate water conditions that were cool-to-temperate during the Oligocene and cooler than for the underlying Eocene (Firth, this volume).

Diatoms occur throughout the Oligocene and uppermost Eocene. Assemblages consist of both high- and low-latitude species and have taxonomic affinities with assemblages described from the Norwegian-Greenland Sea, low-latitude Atlantic, Pacific, and high-latitude South Atlantic. Radiolarian assemblages lack many of the low-latitude stratigraphic indicators and also have similarities with Norwegian-Greenland Sea and Southern Ocean assemblages (Srivastava, Arthur, et al., 1987; Baldauf et al., this volume).

\section{SUMMARY AND CONCLUSIONS}

1. The presence of Rhombodinium? sp. B in Sample 105647A-70R-4, 42-45 cm, suggests an Eocene or Oligocene age for 
this sample, while the presence of D.? condylos in Sample 105647A-69R, CC indicates an early to early middle Eocene age (based on its range of upper Zone NP11 to Zone NP14 from the Rockall Plateau) for this sample. Dinocyst assemblages are consistent with the early Eocene age assignment provided by nannofossils for lowermost sediments in Hole 647A. The lower Eocene biostratigraphic determination of these sediments agrees with the identification of magnetic anomaly 24 at Site 647.

2. The preliminary dinocyst stratigraphy reported here is in general agreement with the nannofossil biostratigraphy for Hole 647. The lower middle and upper lower? Eocene is barren of nannofossils and may contain a hiatus of about $6 \mathrm{Ma}$. Results of dinocyst stratigraphy through this interval, while not conclusive, suggest a hiatus that is located between Samples 105-647A65R-1, 117-121 cm, and -66R-1, 66-69 cm, and/or between Samples 105-647A-63R-1, 139-142 cm, and -64-3, 88-91 cm.

3. Today, Site 647 is situated off the Labrador shelf in deep water $(3858.5 \mathrm{~m})$. Geological evidence, including paleobathymetric estimates from benthic foraminifers and backstripping calculations, indicates a bathyal setting for Site 647 during the early Eocene (Kaminski et al., this volume). Palynomorph assemblages throughout the Paleogene of Hole 647 contain low proportions of pollen and spores, compared to dinocysts, and a consistent presence of Impagidinium spp., reflecting open-ocean conditions and distance from shore. Increased abundances of Wetzeliellaceae in the lower Eocene, however, might indicate a greater influence from shelf environments before increased separation of the North Atlantic margins by seafloor spreading (Fig. 2).

4. Throughout the Eocene of Hole $647 \mathrm{~A}$, dominant dinocyst species have fluctuating abundances, while many others have sporadic occurrences. A similar feature was noted for lower and middle Eocene dinocyst assemblages from the Rockall Plateau. Such mechanisms as ocean-current instabilities (Costa and Downie, 1979b), or more generally, fluctuations in water-mass properties and dynamics, provide possible explanations for this effect at both localities. The presence of well and poorly preserved specimens coexisting in the same sample occurs throughout the Paleogene of Hole 647A, although this seems particularly evident in the middle and upper Eocene. This preservational phenomenon was also noted for upper lower and middle Eocene dinocyst assemblages from Site 406, Rockall Plateau (Costa and Downie, 1979b) and may reflect mixing of penecontemporaneous populations, transported from different shelf and shelf slope environments, as suggested by Costa and Downie (1979b). It is also possible that bioturbation of sediments (common in Hole 647A Paleogene sediments) has imparted preservational unevenness upon assemblages. Fechner and Mohr (1988) invoked a sedimentary mud-turbidite model to explain similar preservational variability in a lower Eocene dinoflagellate assemblage from Germany. Whichever processes are involved, it seems likely, particularly in view of the predominantly shelf distribution of modern cyst-producing dinoflagellates, that many components of deep-water dinoflagellate cyst assemblages (including those of Hole 647A) are allochthonous to some degree.

5. Lower Eocene dinocyst assemblages are generally similar to coeval assemblages from the Rockall Plateau, which presumably partly reflects geographic proximity between the two localities at this time (Fig. 2; Owen, 1983, Map 17). Middle to upper Eocene dinocyst assemblages from Site 647 are similar to those from eastern North Atlantic and northwestern Europe and reflect temperate surface waters. In addition, several species occur (e.g., Histiocysta sp. of Goodman and Ford, 1983 and Elytrocysta sp. of Goodman and Ford, 1983) that previously were reported only from the Norwegian-Greenland Sea, offshore eastern U.S., southwestern Atlantic, and Australasia. That these species are common at Site 647 and apparently absent from the eastern North Atlantic may suggest an affinity between the southwestern North Atlantic and Site 647 that is not shared with the eastern North Atlantic. Perhaps the distribution of these species in the North Atlantic and contiguous areas is related to the intensification of the proto-Gulf Stream that occurred from middle Eocene time (Poag, 1987). Dinocyst assemblages from the Oligocene include a cosmopolitan component, together with a number of species that have been recorded from high northern latitudes, suggesting a partial influence of arctic water masses. The presence of protoperidineacean species in the upper Eocene and Oligocene may indicate increased availability of nutrients, perhaps related to increased upwelling or the effects of watermass mixing during this time.

\section{STRATIGRAPHIC AND MORPHOLOGIC NOTES ON SELECTED DINOCYST TAXA}

This section contains morphologic notes on selected species that are considered characteristic and possibly diagnostic of certain intervals in Hole 647A. No new dinocyst taxa are described. Formal nomenclature generally follows that of Lentin and Williams (1985).

Also discussed in this section are the stratigraphic and geographic distributions of certain dinocyst taxa that appear useful for preliminary stratigraphic and paleoecological interpretation of Hole $647 \mathrm{~A}$. We have attempted, during a detailed literature survey (see below and Table 2), to delineate selected dinocyst ranges where possible, using the standard calcareous nannofossil zonation of Martini (1971; Zones NP1 through NP25 for the Paleogene). For those dinocyst records tied to the low-latitude calcareous nannofossil zonation of Okada and Bukry (1980; Zones CP1 through CP19 for the Paleogene), the equivalent NP zone has also been given (using the correlation of Martini and Müller, 1986). The results of this literature survey encourage our view that Paleogene dinocyst stratigraphy, while still in its infancy, has a potential for high-resolution biostratigraphy that is at least equivalent to that obtained from calcareous nannofossils and planktonic foraminifers.

\section{Notes on Plate Captions}

Abbreviations used in plate captions are as follows: Optical system: $\mathrm{BF}=$ bright field; IC = interference contrast. Specimen orientation and focal plane: antap. = antapical; ap. = apical; ds. = dorsal surface; dv. = dorsal view; f. = focus; hf. = high focus; lat. = lateral; lf. = low focus; lrf. = lower focus; ls. = lower surface; mag. = magnification; $\mathrm{mf}$. = mid-focus; rt. = right; $s .=$ surface uncert. = uncertain; us. = upper surface; v. = view; vs. = ventral surface; vv. = ventral view. Specimen dimensions: dia. = maximum (unless stated otherwise) diameter; dia. incl./exclu. proc.) $=$ diameter (including/excluding processes); $\max$. = maximum.

For each figured specimen in the plates, information is provided in sequence, as follows: sample number, microscope slide number, in parentheses (preceded by the letter $\mathrm{K}$, for samples supplied by M. Kaminski), England Finder coordinates, dimension(s) of figured specimen, and abbreviated details of specimen orientation and focus level.

Division PYRRHOPHTA Pascher, 1914

Class DINOPHYCEAE Fritsch, 1929

Order PERIDINIALES Haeckel, 1894

Genus ADNATOSPHAERIDIUM Williams and Dowie, 1966

Adnatosphaeridium robustum (Morgenroth, 1966a) De Coninck, 1975 (Pl. 13, Fig. 3)

Remarks. A. robustum has a recorded range of uppermost Paleocene (Zone NP9 of Belgium, in De Coninck et al., 1981; Denmark, in Heilmann-Clausen, 1985; Nielsen et al., 1986; S. India, in Jain and Garg, 1982; Zone NP8 of Virginia, U.S.A., in Gibson et al., 1980; 
Maryland, U.S.A. in Edwards et al., 1984) to Zone NP14/15 (middle Eocene) of southern England (Islam, 1983b, 1983c). Lower Eocene European records include Morgenroth (1966a); Gruas-Cavagnetto (1970); De Coninck (1975, 1977, 1980b); Eaton (1976); Bujak et al. (1980); De Coninck et al. (1983); Islam (1983b, 1983c, 1984); Michoux (1985); and Nielsen et al. (1986). A. robustum was recorded exclusively from Zone NP12 in both the Goban Spur (Brown and Downie, 1985) and Rockall Plateau (Brown and Downie, 1984); is restricted to lower Eocene sediments of the Freydis B. 87 well on the Labrador Shelf $(D$. varielongitudum and lower $D$. condylos zones of Ioakim, 1979) and has a highest occurrence within the lower Eocene, Zone NP12, in Virginia and Maryland, U.S.A. (Gibson et al., 1980; Edwards et al., 1984). Its restricted occurrence in lowermost sediments of Hole 647A supports an apparent lower Eocene range for this species in the North Atlantic.

Genus ALISOCYSTA Stover and Evitt, 1978

$$
\begin{aligned}
& \text { Alisocysta sp. cf. A. ornata (Cookson and Eisenack, 1965) } \\
& \text { Stover and Evitt, 1978 } \\
& \text { (Pl. 6, Fig. 6) }
\end{aligned}
$$

Remarks. Specimens are thick-walled (about 1.0-1.8 $\mu \mathrm{m}$ ), have low $(2.0-4.0 \mu \mathrm{m})$ penitabular ridges that become thin and transparent distally, and have a surface ornament of faint irregular granules of about 1.0 to $2.0 \mu \mathrm{m}$ or less in diameter. Some fusion may occur between adjacent granules. Paratabulation in the parasulcal region is expressed weakly, but was not determined in detail. Stover (1975) redescribed Alisocysta ornata from observations of the holotype, paratypes, and numerous topotypes, and specimens that he illustrated appear similar to those less heavily ornamented specimens in this study.

$A$. ornata has been recorded from upper Eocene sections of several localities in southeastern Australia (Cookson and Eisenack, 1965; Stover, 1975). It is also apparently restricted to the upper Eocene of New Zealand (Wilson, 1982, 1984; Clowes, 1985) and has been recorded from the uppermost Eocene of DSDP Site 511, southwestern Atlantic (Goodman and Ford, 1983). It has been recorded from the middle Eocene (Barss et al., 1979) and upper Eocene (Williams and Brideaux, 1975) of offshore eastern Canada.

Alisocysta sp. cf. A. ornata was recorded here from Samples 105647A-63R, CC and -59R, CC, assigned to the upper lower? and middle Eocene (Zones NP13? and NP15; Firth, this volume).

\section{Alisocysta sp.}

(Pl. 6, Fig. 10)

Remarks. This species was recorded in Samples 105-647A-65R-1, $117-121 \mathrm{~cm}$, and $-36 \mathrm{R}, \mathrm{CC}$ from upper lower? or middle Eocene through upper Eocene (Zones NP13/15 to NP18/20; Firth, this volume) of Hole $647 \mathrm{~A}$. Cysts are autophragmal, with a thick wall (about $1.0-1.5 \mu \mathrm{m}$ ) and low $(1.0-1.2 \mu \mathrm{m})$ penitabular ridges that have rounded crests. Intratabular surface is variable and may be finely foveolate to granulate, with irregular fusion of adjacent granules, or may bear a low, rather irregular reticulum (muri, about $1.0-1.5 \mu \mathrm{m}$ wide; lacunae about $1.0-3.0 \mu \mathrm{m}$ diameter). In addition, the surface may be finely pitted.

This species was recorded by Ioakim (1979) as Eisenackia sp. 3 from the upper Paleocene and lower Eocene of the Freydis B. 87 well, and lower Eocene of the Bjarni H. 81 well, both from the Labrador Shelf.

\section{Genus AREOSPHAERIDIUM Eaton, 1971}

\section{Areosphaeridium arcuatum Eaton, 1971}

Remarks. A number of Eocene records exist for this species (see Sarjeant, 1981 for a comprehensive list; also, Manum, 1976; De Coninck, 1980b; Chateauneuf, 1980; Bujak et al., 1980; Van Couvering et al., 1981; Islam, 1983a, 1983b, 1984; Head, 1984; Edwards, 1984; Michoux, 1985; Murray et al., 1987; Mao and Norris, 1988; Manum et al., in press). However, one cannot be certain that Southern Hemisphere specimens so far attributed to $A$. arcuatum, or synonymized with it (e.g., as A. diktyostilum [Menendez] Sarjeant, and A. capricornum [Cookson and Eisenack] Stover and Evitt) should be assigned to this species.

Northern Hemisphere Oligocene records of $A$. arcuatum include: offshore eastern U.S.A. (G. ampliapertura foraminiferal zone $\equiv$ lower NP23, in Stover, 1977), France (Chateauneuf, 1980, correlated to lower Zone NP23, from Aubry, 1985), the Norwegian Sea (lower Oligocene, Manum et al., in press), and N. Germany (Gerlach, 1961 ["middle" Oligocene but possibly reworked, see Sarjeant, 1984, p. 86]).
A. arcuatum has an apparent range of lower middle Eocene (upper Zone NP14, in Bujak et al., 1980, correlated from Aubry, 1985-or possibly slightly lower, see Islam, 1983a, p. 235) to lower Oligocene (lower Zone NP23, in Chateauneuf, 1980, and Stover, 1977). Haq et al. (1987) gave a slightly higher last occurrence in lower Zone NP24, at the lower/ upper Oligocene boundary.

\section{Areosphaeridium diktyoplokus (Klumpp, 1953) Eaton, 1971} (Pl. 13, Figs. 5, 9)

Remarks. Only those forms of $A$. diktyoplokus having unbranched process stems and irregular distal platform margins were recorded in Hole 647A and have a lowest appearance in Sample 105-647A-63R-1, 139-142 cm. Sarjeant (1981) reexamined the holotype of $A$. diktyoplokus and confirmed Eaton's (1971) emendation of the species. He further noted that the distal process terminations of both the holotype and paratype have irregular and not entire margins, which will be of significance should Eaton's (1971) proposed lineage of this species (which includes specimens having entire margins) be subdivided (Sarjeant, 1981, p. 114).

A. diktyoplokus has been widely reported from the Eocene to Oligocene of the Northern Hemisphere (Ioakim, 1979; Chateauneuf, 1980; Liengjajern et al., 1980; Van Couvering et al., 1981; Islam, 1983a, 1983b, 1984; McLean and Hein, 1984; Bujak, 1984; Head, 1984; Michoux, 1985; Mao and Norris, 1988; Biffi and Manum, 1988; Manum et al., in press; see also Eaton, 1976 and Sarjeant, 1981 for further references). It is possible that none of the Southern Hemisphere forms presently recorded (e.g., Archangelsky and Fasola, 1971; Regali et al., 1974; Wrenn and Hart, 1988, and references therein; and as A. sp. cf. A. diktyoplokus of Goodman and Ford, 1979, and references therein) are strictly conspecific with the Northern Hemisphere A. diktyoplokus (see Goodman and Ford, 1979, p. 865; Stover et al., 1988). In particular, it may be worthwhile to determine if some of these specimens have paracingular processes, as has been suggested by Archangelsky and Fasola (1971, p. 10, and text-fig. on p. 11) for Eocene specimens from Argentina (paracingular processes are absent or occasionally represented by one or two slender processes on specimens observed from southern England by Eaton, 1971). Furthermore, the late middle and late Eocene Northern Hemisphere morphotype of $A$. diktyoplokus that is characterized by entire margined process platforms (Eaton, 1971; Bujak, 1976; this does not, however, characterize the holotype or paratype), has not so far been recorded from the Southern Hemisphere (Goodman and Ford, 1979; Wrenn and Hart, 1988).

A. diktyoplokus has a lowest occurrence in the upper lower Eocene, (lower Zone NP13 of southern England, in Bujak et al., 1980, correlated in Aubry, 1985; upper Zone NP13 from Site 405, Rockall Plateau, in Costa and Downie, 1979b, correlated from Müller, 1979). Stover et al. (1988) in their morphologic and stratigraphic review of Areosphaeridium indicated that $A$. diktyoplokus was restricted to the Eocene, and Costa et al. (1985), Williams and Bujak (1985), and Haq et al. (1987) all indicated that this species has a highest occurrence at the Eocene/Oligocene boundary. At the Monte Conero section of central Italy, A. diktyoplokus has a highest occurrence near the Eocene/Oligocene boundary (Biffi and Manum, 1988). However, the boundary at this section is placed higher by the foraminiferal zonation than by the nannofossil zonation, so that the highest occurrence of $A$. diktyoplokus is either uppermost Eocene (foraminiferal Zone P17-P19 as favored by Biffi and Manum) or lower Oligocene (nannofossil Zone NP21-NP22). Elsewhere a range, into the Oligocene, is also suggested by the following records: the lower Oligocene of Belgium (Weyns, 1970, correlated to Zone NP21 in Martini and Moorkens, 1969, see also Hooyberghs, 1980); lower Oligocene of north Germany (Zones NP21 to lower NP23, Benedek and Müller, 1976), and a putative lower Oligocene record from central East Greenland (Soper and Costa, 1978).

\section{Areosphaeridium pectiniforme (Gerlach, 1961) Stover and Evitt, 1978} emend. Sarjeant, 1984

Remarks. This species was considered a senior synonym of Areosphaeridium multicornutum Eaton by Sarjeant (1984), who also gave a comprehensive list of previous records and proposed a range of middle Eocene to upper Oligocene. A. pectiniforme has a lowest occurrence within Zone B-5 of Bujak et al. (1980) in southern England (correlated to Zone NP16 in Aubry, 1985; also recorded in a sample assigned to both nannofossil Zone NP15/16 and dinoflagellate Zone BAR-1 of Bujak et al., 1980, in Murray et al., 1987, p. 173), and possibly a slightly 
lower occurrence within the upper Lutetian of the Paris Basin (Chateauneuf, 1980) and undifferentiated Lutetian of southwestern France (Michoux, 1985). A. pectiniforme was reported from sediments assigned to Zone NP14 (in Müller, 1979) by Costa and Downie (1979b) from the Rockall Plateau, DSDP Site 406. However, Williams and Bujak (1985) in their stratigraphic compilation placed the lowest occurrence of $A$. pectiniforme within upper Zone NP15, which more closely agrees with the northwestern European records. Oligocene records include the lower Oligocene of offshore eastern Canada (Williams and Bujak, 1977a, 1977b; Barss et al., 1979) (and a middle or upper Oligocene occurrence for a "large form," Barss et al., 1979, p. 81), lower Oligocene (Rupelian) of Germany (Gerlach, 1961; Benedek, 1972; Sarjeant, 1984), lower Oligocene of Belgium (Weyns, 1970, correlated to Zone NP21 in Martini and Moorkens, 1969, see also Hooyberghs, 1980), and middle or upper Oligocene of Egypt (El-Beialy, 1988). Benedek and Müller $(1974,1976)$ recorded $A$. pectiniforme from the lower and lower upper Oligocene (Zones NP23 and NP24) of northwest Germany. We consider the highest established occurrence of $A$. pectiniforme to be within Zone NP24 (uppermost lower or lower upper Oligocene), with higher records (e.g., upper Oligocene of Germany, Brosius, 1963; lower Miocene of Belgium, Benedek, 1980), pending verification.

\section{Genus CHIROPTERIDIUM Gocht, 1960}

Chiropteridium mespilanum (Maier, 1959) Lentin and Williams, 1973

$$
\text { (Pl. 5, Figs. 3,6) }
$$

$$
\text { and }
$$

Chiropteridium lobospinosum (Gocht, 1956) Gocht, 1960

$$
\text { (Pl. 5, Fig. 5) }
$$

Remarks. C. mespilanum (formerly C. dispersum), C. lobospinosum, and intermediate forms, were recorded only from the Oligocene of Hole 647A and occur collectively from Samples 105-647A-22R, CC through -15 R, CC (Zones NP23 through NP24/25 in Firth, this volume). These species are considered to have last occurrences within the upper Oligocene, which may be near the Oligocene/Miocene boundary, in a number of localities (northern North Sea, Costa, 1980; northern North Pacific and North Atlantic, Bujak, 1984; central Italy, Biffi and Manum, 1988; Norwegian Sea, Manum et al., in press), although elsewhere, Chiropteridium possibly ranges into the Miocene (e.g., lower Miocene $C$. dissimilis planktonic foraminiferal zone, eastern U.S. continental slope, in Stover, 1977; lower Miocene Zone N-6 [approximately] planktonic foraminiferal zone of South Carolina, U.S., in Edwards, 1986; see Powell, 1986a, p. 96, and Head et al., c, this volume, for discussion of other Miocene records).

A comprehensive review of published records of $C$. mespilanum was provided by Sarjeant (1983, as C. galea, see Lentin and Williams, 1985). Williams and Bujak (1985) and Haq et al. (1987) gave the highest occurrence of C. mespilanum (as C. dispersum) within the lower lower Miocene (lower Zone NN1, Haq et al. 1987), while Williams and Bujak (1985) placed the lowest occurrence of $C$. mespilanum within the upper Eocene Zone NP18. However, Sarjeant (1984) suggested a lower Oligocene range base for $C$. mespilanum, considering that all Eocene records were to some degree dubious.

Williams and Bujak (1985) and Haq et al, (1987) placed the highest occurrence of $C$. lobospinosum slightly lower than that of $C$. mespilanum, at the Oligocene/Miocene boundary. They placed the lowest occurrence of $C$. lobospinosum within the lower Oligocene (lower Zone NP23, Haq et al. 1987).

\section{Genus CORDOSPHAERIDIUM Eisenack, 1963 emend. Davey, 1969 \\ Cordosphaeridium funiculatum Morgenroth, 1966a}

Remarks. C. funiculatum (described by Morgenroth, 1966a from the lower Eocene of Germany) differs principally from Operculodinium divergens (Eisenack, 1954) Stover and Evitt, 1978 (described by Eisenack, 1954 from what is now regarded as the upper Eocene of Germany) in having no more than one process per paraplate. In addition, it appears from the illustrations of the respective paratypes that the periphragm of $C$. funiculatum is more coarsely reticulated than that of $O$. divergens. Nevertheless, a preliminary investigation of the published records of $O$. divergens and $C$. funiculatum suggests cases of confusion between these two species. A detailed appraisal of these records is not attempted here, but $C$. funiculatum may have a slightly higher stratigraphic top (uppermost Eocene or lowermost Oligocene of central Italy as $C$. cf. funiculatum, Biffi and Manum, 1988; lower Oligocene of the following: Paris Basin, France, Chateauneuf, 1979, 1980; Tarim Basin, China, Mao and Norris, 1988; and this study), compared with that of $O$. divergens (given as uppermost Eocene, Zone NP21, in Haq et al., 1987). C. funiculatum may also have a slightly lower range base within the Eocene than $O$. divergens (S. P. Damassa, pers. comm. to M.J.H., 1988).

Several specimens assigned in this study to $C$. funiculatum were recorded from the upper Eocene Sample 105-647A-33R, CC (Zone NP19/ 20 , Firth, this volume), and a single specimen was recorded from the lower Oligocene Sample 105-647A-28R-4, 88-91 cm.

C. funiculatum has an apparent stratigraphic range of lower Eocene (Bed R5 of the Røsnas Clay, Denmark, in Nielsen et al., 1986, correlated to upper Zones NP11 or NP12 in Nielsen and Heilmann-Clausen, 1988; North Sea, Zone NP13, in Lott et al., 1983) to lower Oligocene (Paris Basin, in Chateauneuf, 1979, 1980; correlated to Zones NP22/ lower NP23 in Aubry, 1985). The paleoecology of this species is not well understood, although Lott et al. (1983) suggested that its early presence in North Sea sequences, as compared to those of onshore Britain, might indicate a preference for more open-marine conditions. This species has been reported from the lower and middle Eocene of the North Sea (Ioakim, 1979; Lott et al., 1983), northwestern Europe (Morgenroth, 1966a; Bujak et al., 1980; Murray et al., 1987), Norwegian-Greenland Sea (Manum, 1976), but has not been recorded in coeval deposits from offshore eastern Canada (Williams and Bujak, 1977b; Barss et al., 1979) and does not seem to occur in the Labrador Sea until the upper Eocene (this study).

\section{Cordosphaeridium funiculatum sensu Williams and Bujak, 1977b}

$$
\text { (Pl. 8, Fig. 5) }
$$

Remarks. The specimen illustrated as Cordosphaeridium funiculatum by Williams and Bujak (1977b, Pl. 2, Fig. 6) from the lower Oligocene of the Scotian Shelf differs from $C$. funiculatum in having more than one process per paraplate. It apparently differs from Operculodinium divergens in having a coarser periphragmal reticulation. Specimens recorded in this study compare closely with Williams and Bujak's illustrated specimen and were recorded from a single sample from the upper Eocene (Sample 105-646A-32, CC). Also observed in this sample was a detached opercular plate bearing two processes.

This species has been reported from the upper Eocene and lower Oligocene of offshore eastern Canada (as C. funiculatum in Williams and Bujak, 1977b and Barss et al., 1979), and from the upper middle Eocene (Gosport Sand and Moodys Branch, Zone NP17, correlation of Frederiksen, 1980, Fig. 3) of Alabama, U.S.A.(as C. funiculatum, in Edwards, 1977).

\section{Cordosphaeridium sp. cf. C. funiculatum Morgenroth, 1966a}

$$
\text { (Pl. 8, Figs. 13,14) }
$$

Remarks. This species occurs abundantly in Sample 105-647A-33R, $\mathrm{CC}$ (upper Eocene). It differs from $C$. funiculatum in having processes that are shorter and mostly broader and that are rounded or truncated distally. Processes are somewhat fibrous and hollow and may have longitudinally aligned fenestrations along their length. A few narrower processes are also present and may represent paracingular (and parasulcal?) processes. Larger processes are restricted to one per paraplate. This species does not appear to have been recorded elsewhere.

\section{Genus CORRUDINIUM Stover and Evitt, 1978}

Corrudinium incompositum (Drugg, 1970) Stover and Evitt, 1978

$$
\text { (Pl. 3, Fig. 15) }
$$

Remarks. Specimens in this study have distinct paratabular and accessory ridges and may have a smooth surface or possess scattered intratabular granules. Specimens both with and without granules have a lowest occurrence in Sample 105-647A-51R, CC. Forms questionably assigned to $C$. incompositum are morphologically intermediate with Corrudinium sp. 2 and have less well-defined paratabulation than does C. incompositum.

C. incompositum has been recorded from the middle to upper Eocene of the following areas: northwestern Europe (Bujak et al., 1980; Murray et al., 1987), northwestern Atlantic (Edwards and Bebout, 1981), Norwegian-Greenland Sea (Manum, 1976; Manum et al., in press), offshore eastern Canada (Williams and Brideaux, 1975; Williams and Bu- 
jak, 1977b; Barss et al., 1979), North Sea (Ioakim, 1979), Labrador Shelf (Ioakim, 1979), and Australia (L. Stover, pers. comm. in Goodman and Ford, 1983, p. 862). Corrudinium cristatum Chateauneuf, 1980 bears a strong resemblance to $C$. incompositum and was recorded from the upper middle Eocene of the Paris Basin (Chateauneuf, 1980, correlated to lower Zone NP16 in Aubry, 1985).

Oligocene records are from the southwestern Atlantic (lower Oligocene, Zone CP16c $\equiv \mathrm{NP} 22$, in Goodman and Ford, 1979, correlated from Wise, 1983), offshore eastern U.S. (G. ampliapertura foraminiferal Zone $\equiv$ lower Zone NP23, in Stover, 1977), France (lower Zone NP23, Chateauneuf, 1980, correlated from Aubry, 1985), North Sea (lower Oligocene, Zone NP22, Ioakim, 1979), central Italy (lower Oligocene, lower Zone NP23, Biffi and Manum, 1988), undifferentiated Oligocene of eastern U.S. (Drugg, 1970), and has been recorded from putative upper Oligocene (Williams and Bujak, 1977b), and "middle" or upper Oligocene sediments (Barss et al., 1979) from offshore eastern Canada.

The above records suggest a range extending from middle middle Eocene (middle Eocene Zone NP15 or older, in Edwards and Bebout, 1981; see P? brooksii below for discussion of age; Zone NP16 in Bujak et al., 1980, correlated from Aubry, 1985; or Zone NP15/16, Murray et al., 1987), to lower Oligocene (lower Zone NP23; Stover, 1977; Chateauneuf, 1980).

\section{Corrudinium sp. 2}

$$
\text { (Pl. 3, Fig. 14) }
$$

Remarks. This species is characterized by low ridges that form a reticulation, which shows indistinct paratabulation, and has a lowest occurrence in Sample 105-647A-66R-1, 66-69 cm.

\section{Genus DEFLANDREA Eisenack, 1938 emend. Lentin and Williams, 1976}

Deflandrea leptodermata Cookson and Eisenack, 1965

$$
\text { (Pl. 12, Figs. 1, 2) }
$$

Remarks. Stover (1973) considered that the granulate periphragmal surface of the type specimens of $D$. leptodermata resulted from over-oxidation. The hypotype illustrated by him, from the type locality (Browns Creek, Australia, middle to upper Eocene) compares with the Hole 647A specimens in having a rounded ambitus with greatly reduced horns and a wide hexa-intercalary archeopyle. This species is common in samples from the upper middle Eocene to lower Oligocene of Hole 647A, but has been recorded infrequently in the published literature on the east Canadian Shelf, although it was reported from provisionally dated sediments of lower Paleocene to upper Eocene age (Barss et al., 1979). D. leptodermata was recorded from upper Eocene through Oligocene sediments in central Italy, where it has a highest occurrence (based on several examined sections) near the Oligocene/Miocene boundary in the uppermost Oligocene (Biffi and Manum, 1988).

\section{Genus DISTATODINIUM Eaton, 1976}

Distatodinium paradoxum sensu Gocht, 1969, Pl. 7, Figs. 5, 6

$$
\text { (P1. 5, Fig. 7) }
$$

Remarks. This species is characterized by long processes having narrow, hollow, tubular stems and distal branches that are also long and narrow. The central body is elongate and a wide equatorial belt is devoid of processes. A single specimen was recorded in this study. This distinctive species has been recorded from the "middle" Oligocene of Germany (Gocht, 1969) and possibly from the lower Miocene? of offshore eastern Canada (as Tanyosphaeridium paradoxum in Williams and Brideaux, 1975, Pl. 20, Fig. 6). It has also been recorded from the lower Oligocene of northwestern Italy, where it occurs in upper Zone NP24 and in Zone NP25 (as Distatodinium? sp. A, in Powell, 1986a) and ranges from latest Eocene through late Oligocene, within Zone NP25 in the North Sea (U. Biffi, pers. comm. to M.J.H., 1986). It was recorded by Biffi and Manum (1988, as D. paradoxum sensu Gocht, 1969) from the upper Oligocene (Zone NP25) of central Italy.

Benedek (1972), in his study of middle and upper Oligocene dinoflagellates from Germany, erected the monospecific genus Microsphaeridium, with $M$. ansistroides as its type, based on three specimens from the upper Oligocene. These three specimens were reexamined by Benedek and Sarjeant (1981), who concluded that these represented the detached opercula of at least two, and possibly three, unidentified species of skolochorate cysts. Benedek and Sarjeant consequently recom- mended that the species name be provisionally restricted to the holotype only. We consider that $M$. ancistroides, based on its overall size, process morphology, small "central body," and stratigraphic occurrence, may represent the detached operculum of the species referred in this study as D. paradoxum sensu Gocht (1969, Pl. 7, Figs. 5,6).

It appears from occurrences cited above (including the German upper Oligocene record of $M$. ancistroides) that $D$. paradoxum sensu Gocht does not range above the upper Oligocene Zone NP25. A single specimen was recorded in this study, and it occurred in Sample 105-647A$22 \mathrm{R}, \mathrm{CC}$, which was assigned to the lower Oligocene (lower Zone NP23, Firth, this volume).

Genus DRACODINIUM Gocht, 1955 emend. Bujak et al., 1980

Dracodinium? condylos (Williams and Downie, 1966) Costa and Downie, 1979a

Remarks. In Hole 647A, D.? condylos is restricted to Sample 105$647 \mathrm{~A}-69 \mathrm{R}, \mathrm{CC}$ and includes specimens that may represent a morphologic continuum with $D$. ? sp. cf. $D$. ? condylos in that sample. In southern England, D.? condylos occurs through the lower part of the $K$. coleothrypta Zone of Costa and Downie, (1976) and Zones LC-3 to lower B-1 of Bujak et al. (1980) and is restricted to Zone NP12. D.? condylos is also restricted to Zone NP12 in DSDP Hole 548A, Goban Spur (Brown and Downie, 1985). In the Rockall Plateau, however, D.? condy. los first appears in the upper Zone NP11 of Hole 553A (Brown and Downie, 1984), Hole 117A (Morton et al., 1983), and upper Zone NP11 or lower Zone NP12 in Site 404 (Costa and Downie, 1979b; Müller, 1979) and has a last appearance in Zone NP14 at Site 405 (Costa and Downie, 1979b; Müller, 1979). A range of upper Zones NP11 to NP14 thus is indicated for $D$. ? condylos. This species was recorded from the Cuisian of the Labrador shelf (Ioakim, 1979).

Dracodinium? sp. cf. D.? condylos (Williams and Downie, 1966) Costa and Downie, 1979a

$$
\text { (Pl. 1, Fig. 6) }
$$

Remarks. D.? sp. cf. D.? condylos, co-occurs with D.? condylos in Sample 105-647A-69R, CC and both morphotypes were recorded only from this sample. $D . ?$ sp. cf. $D$. ? condylos is similar to the specimen assigned to $D$. varielongitudum by Heilmann-Clausen (1985, Pl. 6, Figs. 9, 10) from the lower Eocene Zone NP11 of Denmark, although it may have a somewhat less prominent apical horn. Specimens in this study have blunt, distally closed processes that are up to $5 \mu \mathrm{m}$ long on midventral and mid-dorsal areas and that are shorter around the lateral margins and on the horns. The apical horn is absent or reduced. D.? sp. cf. D.? condylos possibly is an intraspecific morphotype of $D$. ? condylos.

Genus DUOSPHAERIDIUM Davey and Williams, 1966, ex Loeblich and Loeblich, 1968

Duosphaeridium sp. cf. D. rugosum Drugg, 1970

$$
\text { (Pl. 12, Fig. 4) }
$$

Remarks. D. rugosum differs from D. nudum (Cookson, 1965) in having a rugulate, rather than finely granulate, wall surface and a larger distal opening in the antapical process (Drugg, 1970). Specimens from Hole 647A do not have the large antapical opening of $D$. rugosum and thus were assigned provisionally. $D$. nudum may have a range of late early to late Eocene (Cookson, 1965; Costa and Downie, 1979b; Barss et al., 1979; Michoux, 1985), although it is restricted to upper Zone NP13 and lower Zone NP14 at Sites 405 and 406 in the Rockall Plateau (Costa and Downie, 1979b). D. rugosum was recorded from the lower Paleocene of eastern U.S.A. (Drugg, 1970) and has a range of upper Paleocene Zone NP3 to middle Eocene Zone NP15 (Williams and Bujak, 1985).

\section{Genus EATONICYSTA Stover and Evitt, 1978}

Eatonicysta ursulae (Morgenroth, 1966a) Stover and Evitt, 1978 (Pl. 9, Fig. 9)

Remarks. E. ursulae has a highest occurrence in Sample 105-647A$65-1,117-121 \mathrm{~cm}$, within an interval assigned to Zone NP13-NP15 (Firth, this volume). This species has an apparent range base in the uppermost Paleocene (upper Zone NP9; Rockall Plateau, in Costa and 
Downie, 1979b). However, onshore sections in northwestern Europe suggest a slightly higher lowest occurrence within upper Zones NP10 or NP11 of the lower Eocene (Heilmann-Clausen, 1982, 1985; Nielsen et al., 1986; Bujak et al., 1980, using the correlation of Aubry, 1985); or undifferentiated Ypresian (De Coninck, 1975, 1980b). Williams and Bujak, (1985, Fig. 19, No. 284) placed the lowest occurrence of $E$. ursulae in the upper Zone NP11. Other lower and middle Eocene records are given in Eaton (1976, and references therein); Williams and Bujak (1977b); Barss et al. (1979); Islam (1984); Brown and Downie (1984, 1985 ); and Manum et al. (in press).

E. ursulae has a range top in the middle Eocene (middle Zone NP16; Paris Basin, France, in Chateauneuf, 1980; Aubry, 1985). It occurs within Zone NP14, below a hiatus at Site 406, Rockall Plateau, and is absent from overlying Zone NP18 (Costa and Downie, 1979b; Müller, 1979).

\section{Genus ELYTROCYSTA Stover and Evitt, 1978}

\section{Elytrocysta sp. of Goodman and Ford, 1983}

$$
\text { (Pl. 3, Figs. 1-3) }
$$

Remarks. Specimens here assigned to Elytrocysta sp. of Goodman and Ford, 1983 occur from Samples 105-647A-63R-1, 105-108 cm, to $-24 \mathrm{R}-2,142-145 \mathrm{~cm}$. Specimens are spherical to broadly elliptical, holocavate, with a thin continuous ectophragm supported by elements that may appear granulate in surface view, or may partially coalesce to form an incomplete reticulation. Archeopyle is apical, with a simple operculum that is commonly adherent (adnate?). Accessory sutures may be developed. This species was recorded from the upper Eocene through lowermost Oligocene of DSDP Hole 511, Southwest Atlantic (Zone CP16ab $\equiv$ NP21, Goodman and Ford, 1983, correlated from Wise, 1983); from the upper Eocene or lower Oligocene of Spitsbergen (M. Head, unpubl. data); and from the upper Eocene and lower Oligocene? of New Zealand (as Chlamydophorella sp. in Clowes and Morgans, 1984).

\section{Elytrocysta sp. A}

(Pl. 3, Figs. 10,11)

Remarks. This species is similar to Elytrocysta sp. of Goodman and Ford, 1983, but indistinct parasutural ridges occur with accessory ridges. Paratabulation is much less well expressed than for Histiocysta spp. of Goodman and Ford, 1983.

\section{Genus GELATIA Bujak, 1984 \\ Gelatia inflata Bujak, 1984 \\ (Pl. 4, Fig. 5)}

Remarks. This species is a characteristic component of the Oligocene of Hole 647A, occurring persistently in Samples 105-647A-24R-2, $142-145 \mathrm{~cm}$, through $-16 \mathrm{R}$, CC (Zones NP22 to NP24/25, Firth, this volume). It previously was reported from the upper Eocene to upper Oligocene of the northern North Pacific (Bujak, 1984) and questionably from the upper Oligocene of northwestern Italy (as Thalassiphora sp. cf. T.? pansa, in Powell, 1986a). A specimen illustrated as Thalassiphora succincta in Ioannides and Colin (1977, Pl. 1, Fig. 11) from the upper Eocene or upper Oligocene of DSDP Site 358, southeastern Atlantic, bears some resemblance to Gelatia inflata.

\section{Genus HEMIPLACOPHORA Cookson and Eisenack, 1965 \\ Hemiplacophora semilunifera Cookson and Eisenack, 1965}

$$
\text { (PI. 5, Figs. 9,10) }
$$

Remarks. This species was recorded from Samples 105-647A-35R, $C C$ and $-36 R, C C$ from the upper Eocene (Zone NP19, Firth, this volume). $H$. semilunifera was recorded from the upper Eocene of Australia (Cookson and Eisenack, 1965); the middle Eocene (Zone NP15/16) of DSDP Site 512, southwest Atlantic (Goodman and Ford, 1983); the upper Eocene of DSDP Site 370, offshore west Africa (Williams, 1978); the upper Eocene of DSDP Sites 1 through 6, offshore Florida (Williams, 1978, p. 793); and the upper Eocene of offshore eastern Canada (Barss et al., 1979).
Genus HETERAULACACYSTA Drugg and Loeblich, 1967 emend. Bujak, in Bujak et al., 1980

\section{Heteraulacacysta porosa Bujak, in Bujak et al., 1980}

(Pl. 8, Fig. 8)

Remarks. $H$. porosa occurs in a short interval from Samples 105 647A-35R, CC through -33R-1, 91-94 cm, just below the Eocene/Oligocene boundary in Hole 647A. This species was recorded from the upper middle Eocene of southern England by Bujak et al. (1980; middle Zone NP16 to lower Zone NP17 of Aubry et al., 1986) and upper middle Eocene of the Paris Basin by Chateauneuf (1980; middle Zone NP16 of Aubry, 1985). $H$. porosa also has been recorded from the provisionally dated upper Eocene and lower Oligocene of offshore eastern Canada (as Dinopterygium sp. A of Williams and Bujak, 1977a in Williams and Bujak, 1977b), and lower or middle Eocene thruugh lower Oligocene of offshore eastern Canada (as Dinopterygium sp. A Williams and Bujak, 1977b, in Barss et al., 1979); and from the upper Eocene or lower Oligocene of Spitsbergen (Head, 1984). In view of the above data, including those data for ODP Site 647, we propose a range of upper middle Eocene (Zone NP16) to uppermost Eocene (Zone NP20) for $H$. porosa, with suggested higher occurrences, pending verification.

\section{Heteraulacacysta sp. A}

$$
\text { (Pl. 8, Fig. 15) }
$$

Remarks. This species is represented by the antapical half of a single specimen in Sample 105-647A-53R-4, 121-125 cm. The periphragm is smooth and perforate. However, perforations do not occur on the paracingular crests, nor do they appear to occur on other parasutural crests. Heteraulacacysta porosa differs in having perforations that cover the entire periphragm. A possibly similar specimen was illustrated as $H$. porosa in Edwards (1984) from the middle Eocene of Virginia (Zone CP14a $\equiv$ NP16, correlated from DiMarzio, 1984) and is of comparable age with Heteraulacacysta sp. C of this study (Zone NP16).

\section{Genus HISTIOCYSTA Davey, 1969a?}

\section{Histiocysta spp. of Goodman and Ford, 1983}

(Pl. 3, Figs. 5 through 9)

Remarks. Specimens assigned to Histiocysta spp. of Goodman and Ford, 1983 occur from Samples 105-647A-53R-4, $121 \mathrm{~cm}$, to $-22 \mathrm{R}, \mathrm{CC}$. Specimens are spherical to broadly ellipsoidal, holocavate, with a thin continuous ectophragm supported by low parasutural and intratabular ridges. Archeopyle is apical, with a simple operculum that is commonly adherent (adnate?). Accessory sutures may be developed. Paratabulation is well developed (apparently microdinioid = partiform, Evitt, 1985) and intratabular ridges usually form a variably developed reticulate or partially reticulate pattern. This species (or species complex) was recorded from the middle Eocene (foraminiferal Zone P11/12; nannofossil Zone NP15/16) to lower Oligocene (upper Zone CP16ab $\equiv$ upper? Zone NP21, correlated from Wise, 1983) of DSDP Holes 511 and 512, southwest Atlantic (Goodman and Ford, 1983) and from the upper Eocene or lower Oligocene of Spitsbergen (M. Head, unpubl. data). Elsewhere, possibly conspecific forms occur as follows: the uppermost Eocene or lower Oligocene of New Zealand (as ?Histiocysta sp. in Clowes and Morgans, 1984); the upper middle Eocene of France (as Microdinium sp. 1 in Chateauneuf, 1980, correlated to Zone NP17 in Aubry, 1985); upper middle Eocene to upper Oligocene of Virginia, U.S. (as Microdinium sp. 1 of Chateauneuf, in Edwards, 1984, correlated to Zone CP14a $\equiv \mathrm{NP} 16$ to Zone CP19 $\equiv \mathrm{NP} 24 / 25$, from DiMarzio, 1984); middle Eocene (foraminiferal Zone P11 [ $\equiv$ middle Zone NP15] correlated in Bybell, 1975) to lower (and upper?) Oligocene of Alabama, U.S. (as Microdinium n. sp. in Edwards, 1977); middle to upper Eocene of the Norwegian/Greenland Sea (as Meiourogonyaulax sp. 1, in Manum, 1976). The first appearance of Histiocysta spp. of Goodman and Ford in Hole 647A (Zones NP15? and lower NP16, Firth, this volume) compares closely with the earliest records listed above, viz. Edwards (1977 [middle Zone NP15]; 1984 [Zone CP14a $\equiv$ NP16]). These records indicate a range of middle Eocene (middle Zone NP15) to upper Oligocene (Zone NP24/25) for Histiocysta spp. of Goodman and Ford, 1983. 
Genus HOMOTRYBLIUM Davey and Williams, 1966

\section{Homotryblium sp. A}

(Pl. 11, Fig. 5)

Remarks. Homotryblium sp. A has a faintly to moderately granulate central body and cylindrical processes that are slightly expanded distally, having denticulate to secate distal margins. Processes number about 16 on specimens (three were recorded) that have lost opercula. This species thus differs from $\mathrm{H}$. oceanicum Eaton in having sulcal processes. $\mathrm{Ho}$ motryblium sp. A was recorded from two samples (105-647A-66R-1, 66$69 \mathrm{~cm}$, and $-68 \mathrm{R}-2,76-79 \mathrm{~cm}$ ) from the lower Eocene of Hole 647A.

\section{Genus IMPAGIDINIUM Stover and Evitt, 1978 \\ Impagidinium? pallidum Bujak, 1984 (Pl. 10, Fig. 13)}

Remarks. I.? paliidum was recorded sporadically from the upper middle Eocene through the upper Oligocene in Samples 105-647A-52R4, 25-28 cm, through -16R, CC (Zones NP16 through NP24/25; Firth, this volume) in Hole 647A. Its previously known stratigraphic range is upper Eocene from the northern North Pacific (Bujak, 1984) to Pleistocene of the Norwegian Sea (Mudie, in press). I.? pallidum has a geographic range of northern North Pacific, Beaufort Sea, Arctic Ocean, Norwegian Sea, Baffin Bay, and the Labrador Sea (see Head et al., a, this volume, for complete review) and may be a useful indicator of cool temperate to boreal water masses (Head et al., a, this volume).

\section{Impagidinium velorum Bujak, 1984}

$$
\text { (Pl. 10, Fig. 11) }
$$

Remarks. I. velorum occurs in low abundances throughout most of the Oligocene interval, from Samples 105-647A-28R-4, 88-91 cm, through $-16 \mathrm{R}, \mathrm{CC}$ (Zones NP21 to NP24/25, Firth, this volume) in Hole 647A. This species has been reported from the middle or upper Eocene to upper Pliocene of the northern North Pacific (Bujak, 1984); the lower or middle Eocene to upper Miocene of ODP Site 643, Norwegian Sea (Manum et al., in press); the lower Miocene to upper Pliocene of the western and northern Pacific (Bujak and Matsuoka, 1986), upper Miocene to upper Pliocene of northwestern Japan (Matsuoka et al., 1987); upper Miocene to upper Pliocene of DSDP Site 607, central North Atlantic (Mudie, 1986); upper Miocene and basal Pliocene of DSDP Site 611, northern North Atlantic (Mudie, 1986); and Paleogene of the Alpha Ridge, Arctic Ocean (Mudie, 1985). From its presently known distribution, $I$. velorum may be typically a high northern-latitude species. Mudie (1986, Table 3) considered it sensitive to cold.

\section{Genus KISSELOVIA Vozzhennikova, 1963 emend. Lentin and Williams, 1976 \\ Kisselovia coleothrypta (Williams and Downie, 1966b) Lentin and Williams, 1976$$
\text { (Pl. 1, Fig. 1) }
$$

Remarks. $K$. coleothrypta was recorded from Sample 105-647A-68R-1, 129-132 cm, to $-28 \mathrm{R}-4,88-91 \mathrm{~cm}$, here. The lowest occurrence of $K$. coleothrypta defines the base of the $K$. coleothrypta Zone of Costa and Downie (1976) which in northwestern Europe occurs within the uppermost Zone NP11 (Costa and Downie, 1976, text Fig. 5) or at the NP11/ NP12 boundary (Costa and Downie, 1976, text Fig. 6; Williams and Bujak, 1985, Figs. 13, 15; Nielsen and Heilman-Clausen, 1988, Fig. 2). In southern England $D$. ? condylos also has a first occurrence at the base of the $K$. coleothrypta Zone (Costa and Downie, 1976; Bujak et al., 1980). However, on the Rockall Plateau, Site 404, the lowest occurrence of $K$. coleothrypta in sediments of Zone NP12 age is slightly higher than that of D. condylos and D. varielongitudum (Costa and Downie, 1979b). The same sequence of first appearances was observed in this study. $K$. coleothrypta also has a first appearance in Zone NP12 in the eastern U.S. (Edwards, 1984; Edwards et al., 1984). K. coleothrypta has a highest persistent occurrence in the lower Oligocene (lower G. opima opima Zone $\equiv$ middle NP23) of offshore eastern U.S.A. (Stover, 1977), and Williams and Bujak (1985) gave a range top just above the lower/upper Oligocene boundary.

Kisselovia crassoramosa (Williams and Downie, 1966) Damassa, 1979 (Pl. 1, Fig. 2)

Remarks. $K$. crassoramosa was recorded only from Sample 105-647A$68 \mathrm{R}-1,129-132 \mathrm{~cm}$, here. This species has been recorded from the lower
Eocene of southern England (Williams and Downie, 1966; Downie et al., 1971; Costa and Downie, 1976; Eaton, 1976; Bujak et al., 1980; Islam, 1984); lower Eocene of Belgium (De Coninck, 1980a, 1980b); lower Eocene of northern Germany (Costa and Downie, 1976); upper lower Eocene (Cuisien) of the Bjarni H. 81 well, Labrador Sea (Ioakim, 1979); Eocene of California, U.S.A. (Damassa, 1979); upper Eocene or lower Oligocene of Renardodden, Spitsbergen (M. Head, unpubl. data) and upper Eocene of Sarsbukta, Spitsbergen (Manum and Throndsen, 1986); and Eocene through lower Oligocene of offshore eastern Canada (upper Eocene in Williams and Bujak, 1977b; middle Eocene through lower Oligocene in Barss et al., 1979).

$K$. crassoramosa has a range of lower Eocene (lower W. meckelfeldensis Zone in both Germany and England $\equiv$ lower Zone NP10; Costa and Downie, 1976) to upper Eocene (Williams and Bujak, 1977b) or lower Oligocene (Barss et al., 1979) of offshore eastern Canada.

\section{Kisselovia edwardsii sensu Caro, 1973 \\ (Pl. 1, Fig. 3)}

Remarks. This species has a lowest occurrence in Sample 105-647A$66 \mathrm{R}-2,29-33 \mathrm{~cm}$. Specimens have a solid ectophragm, which possibly envelopes the entire cyst (although the thin nature of the ectophragm prevented us from determining this in the mid-dorsal and mid-ventral areas with certainty). $K$. edwardsii sensu Caro, 1973 has processes that are more robust than in $K$. coleothrypta and are short and sparsely distributed in the mid-dorsal and mid-ventral areas. $K$. coleothrypta also differs in having distinct parasutural breaks in the ectophragm. K. edwardsii (Wilson) Stover and Evitt, 1978, described from the lower Eocene of New Zealand (Wilson, 1967), differs from $K$. edwardsii sensu Caro, 1973 in the absence of processes in the mid-dorsal and mid-ventral areas. Manum (1980) gave a provisional range of Zones NP12 to NP14 (lower part of the $K$. coleothrypta Zone Costa and Downie, 1976) for $K$. edwardsii sensu Caro in northwestern Europe. This species was also recorded from Zone NP13 in Hole 553A on the Rockall Plateau (as $K$. edwardsii, in Brown and Downie, 1984); from the Cuisian (= upper lower Eocene) of the North Sea (as K. edwardsii, from the "M." ursulae and $K$. edwardsii zone in Ioakim, 1979), and Cuisian of the Labrador Shelf (as $K$. edwardsii from the $K$. edwardsii Zone of the Freydis B. 87 well, in Ioakim, 1979; and both $K$. edwardsii and D. condylos zones of the Freydis B. 87 well, in Ioakim, 1979), and from the lower middle Ilerdian (lower Eocene) of Spain (as W. edwardsii, in Caro, 1973). In Site 647 , this species has a restricted and persistent occurrence from Samples 105-647A-66R-2, 29-33 cm, through -64R-3, 88-91 cm (assigned to Zone NP13 through lower Zone NP15?, in Firth, this volume). Given the somewhat imprecise nature of the above data, we propose a conservative range of Zone NP12? or Zones NP13 through NP14 or lower Zone NP15? for this species.

Genus LITOSPHAERIDIUM Davey and Williams, 1966 emend. Lucas-Clark, 1984

Litosphaeridium sp. A

(Pl. 11, Figs. 4, 8)

Remarks. This species has a spherical central body with a smooth to faintly granulate surface, and an apical archeopyle with accessory sutures. The operculum is free. Processes are broad, cylindrical, of approximately equal size with a smooth surface, and may be finely striate along the proximal one-third of the length. Process terminations are parallel and straight to slightly uneven. The process formula may be 6", $0 \mathrm{c}, 5,0-1 \mathrm{p}, 1^{\prime \prime \prime \prime}$ (12 to 13 processes in all). This species is probably conspecific with the specimen illustrated as Homotryblium oceanicum in Costa and Downie, 1979b (Pl. 3, Fig. 5) from DSDP Site 406, Rockall Plateau (Zone NP14 from Müller, 1979). The species is also similar to Litosphaeridium sp. 2 of Ioakim, 1979, recorded from the lower middle Eocene of the Freydis B. 87 well, Labrador Shelf, although processes on this species were reported to number 13 to 15 (Ioakim, 1979). Litosphaeridium $\mathrm{sp} A$. was recorded from two samples (105-647A-65R-1, 117-121 $\mathrm{cm}$, and $-64 \mathrm{R}, \mathrm{CC}$ ) from the upper lower or middle Eocene.

\section{Litosphaeridium? sp. B} (Pl. 11, Fig. 11)

Remarks. Specimens may be detached opercula. The wall surface is smooth. Processes are cylindrical to slightly flared, and the distal margin is entire and may be slightly expanded. The process wall is smooth or may be granulate along the proximal two-thirds. Four to five processes are present. 
Genus PHTHANOPERIDINIUM Drugg and Loeblich, 1967 emend. Edwards and Bebout, 1981

Phthanoperidinium? brooksii Edwards and Bebout, 1981 (Pl. 10, Figs. 1,2)

Remarks. The generic assignment of $P$ ? brooksii is questioned because of the unusual and broadly spatulate shape of the first precingular paraplate $\left(1^{\prime}\right)$, which, as Edwards and Bebout $(1981$, p. 40) stated, occurs on no other species of Phthanoperidinium.

Phthanoperidinium? brooksii previously has been reported only from the middle Eocene of the New Jersey, U.S. continental slope, ASP Corehole 15 (Edwards and Bebout, 1981). These sediments can be dated by the presence of two calcareous nannofossil species, Transversopontis obliquipons and Rhabdosphaera gladius, with the latter marking the top of Zone NP15 (Perch-Nielsen, 1986), which jointly signify a middle Eocene age (Edwards and Bebout, 1981, p. 29). The dinocyst Corrudinium incompositum co-occurs with $P$ ? brooksii in ASP Corehole 15 (Edwards and Bebout, 1981), and since this species is not known to range below Zone NP15 (see this chapter), the interval containing this dinocyst assemblage can probably be assigned to Zone NP15. In this study, $P$ ? brooksii was recorded (in a single sample, 105-647A-59R, CC) from the middle middle Eocene (upper Zone NP15, Firth, this volume), which is comparable with its occurrence in ASP Corehole 15.

\section{Phthanoperidinium comatum (Morgenroth, 1966b) Eisenack and Kjellström, 1971}

Remarks. This species ranges from Samples 105-647A-61R, CC through $-24 \mathrm{R}-2,142-145 \mathrm{~cm}$. $P$. comatum has been recorded from the Eocene of Europe (Chateauneuf, 1980; Liengjarern et al., 1980; Bujak et al., 1980; Islam, 1982, 1983b; Murray et al., 1987 and as " $P$. tritonium," in Eaton, 1976; De Coninck, 1977, and Michoux, 1985); southwestern Atlantic (Goodman and Ford, 1983), eastern U.S. (Edwards, 1984), northeastern Atlantic (Costa and Downie, 1979b); offshore eastern Canada (Williams and Bujak, 1977b); North Sea (Ioakim, 1979); offshore northeastern Africa (Williams, 1978); and Australia (L. Stover, pers. comm., in Goodman and Ford, 1983, p. 862). It has been recorded from the lower Oligocene of Europe (Morgenroth, 1966b; Liengjarern et al., 1979; Chateauneuf, 1980; Biffi and Manum, 1988), basal Oligocene of the North Sea (Ioakim, 1979), lower Oligocene of the southwestern Atlantic (Goodman and Ford, 1983), lower Oligocene of offshore eastern U.S. (Stover, 1977), lower and lower upper? Oligocene of the northeastern Atlantic (Costa and Downie, 1979b), undifferentiated Oligocene of the Norwegian-Greenland Sea, (as Phthanoperidinium sp. 1 in Manum, 1976), lower Oligocene of the Nile Delta, Egypt (El-Beialy, 1988), and from provisionally dated lower and upper Oligocene sediments of offshore eastern Canada (Williams and Bujak, 1977b; Barss et al., 1979). These records suggest that $P$. comatum has a range from upper lower Eocene (upper Zone NP13, Costa and Downie, 1979b, correlated in Müller, 1979; and Zone NP13/14, Bujak et al., 1980, correlated in Aubry, 1985) to lower Oligocene (Zone NP23, in Chateauneuf, 1980, correlated in Aubry, 1985; lower Zone NP23 in Biffi and Manum, 1988; G. ampliapertura foraminiferal Zone $\equiv$ lower Zone NP23 in Stover, 1977).

\section{Genus RHOMBODINIUM Gocht, 1955 emend. Bujak, 1979}

Remarks. Bujak (1979) restricted this genus to species having a soleiform archeopyle; i.e., a quadra-archeopyle in which the periarcheopyle lies directly above the endoarcheopyle and in each of which the operculum has rounded corners on the posterior margin and remains in contact with the cyst along its anterior (adapical) margin (Bujak, 1979, p. 309; Bujak and Davies, 1983, p. 169). The line drawings in Bujak (1979, text Figs. 4A and 8) may be taken to indicate an adnate opercular condition in which the principle archeopyle suture is interrupted along the adapical margin (see Evitt, 1985, p. 126 for definitions of terminology). Indeed, all specimens of Rhombodinium that were observed by Bujak from the middle and upper Eocene of southern England have attached opercula in which no indications of the principle suture (i.e., a line of structural discontinuity) were noticed along the adapical archeopyle margin (Bujak, pers. comm to M.J.H., 1988). However, Gocht's (1955, Fig. 1c) line drawing of the holotype of the type species (Rhombodinium draco) from the "middle" Oligocene of northern Germany indicates a completely encircling principle archeopyle suture. This might be an artifact in which the adapical archeopyle margin was misinter- preted for a fold; nevertheless Gocht's specimens leave some doubt as to whether the operculum in Rhombodinium is indeed adnate or whether it is adapically adherent (as a consistent feature) with a continuous encircling principle archeopyle suture. This distinction is important, not least of all since the latter case can only be recognized with specimens where the archeopyle has opened.

In their proposed phylogenetic relationship of the Wetzelielloideae, Bujak and Davies (1983, text Fig. 31) suggested a middle Eocene earliest appearance for Rhombodinium. This is supported by Williams and Bujak's (1985, Fig. 19) compiled stratigraphic ranges of four species of $R$ hombodinium $(R$. draco, $R$. porosum, $R$. longimanum, and $R$. perforatum), in which the lowest ranging species, $R$. draco, has a reported lowest occurrence in the upper middle Eocene Zone NP16. This postdates the occurrence of a complex of species (including Rhombodinium? spp. A, B, and C of this study, and "Rhombodinium" glabrum), that first appeared in the early Eocene and that are characterized by an operculum that is free (i.e., having a continuous principal archeopyle suture) but that may be attached along the adapical margin (see " $R$." glabrum below). One is tempted to draw an evolutionary line between this " $R$." glabrum complex and later Rhombodinium species, although much remains to be understood regarding the taxonomic significance and evolution of the soleiform archeopyle.

"Rhombodinium" glabrum (Cookson, 1956) Vozzhennikova, 1967

Remarks. This species was not discussed by Bujak (1979) in his emendation of Rhombodinium, but clearly it possesses a free, detached operculum (Cookson, 1956), which excludes it from Rhombodinium as emended by Bujak, and for which reason we have retained it only tentatively in this genus.

Two specimens were assigned here to " $R$." glabrum; both have free opercula (detached in one specimen) and were recorded in Sample 105$67 \mathrm{R}-4,23-26 \mathrm{~cm}$. They differ from Rhombodinium? sp. C (Pl. 1, Fig. 8, recorded in the same sample) in having a detached operculum, but are otherwise similar and are possibly conspecific with this morphotype.

"R." glabrum has been previously recorded from the lower Eocene Zone NP12 of the Goban Spur (Brown and Downie, 1985); from the middle Eocene of Virginia, U.S. (Zone CP14a $\equiv$ NP16, Edwards, 1984, correlated from DiMarzio, 1984); from the middle Eocene of New Zealand (Wilson, 1984); and from undifferentiated Eocene sediments of Australia (Cookson, 1956).

\section{Rhombodinium? sp. A, sp. B, and sp. C} (PI. 1, Figs. 7 through 9)

Remarks. Specimens assigned to Rhombodinium? sp. A (Pl. 1, Fig. 7; Sample 105-647A-68R-2, 76-79 cm) and Rhombodinium? sp. C (Pl. 1, Fig. 8; Sample 105-647A-67R-4, 23-26 cm) have opercula that are attached (possibly adnate) along the adapical archeopyle margin. The operculum in specimens assigned to Rhomobinium? sp. B (Pl. 1, Fig. 9; Sample 105-647A-70R-4, 42-45 cm) is free, and in some specimens is detached, and in others is adherent along the adapical archeopyle margin. This species also is characterized by a thick (1.0 to $1.5 \mu \mathrm{m})$ periphragm.

Genus SAMLANDIA Eisenack, 1954 Samlandia chlamydophora Eisenack, 1954 (Pl. 12, Fig. 7)

Remarks. S. chlamydophora has been recorded from the Eocene of Europe (Eisenack, 1954; as "Palmnickia aff. lobifera" in Evitt, 1961; Morgenroth, 1966a; "P. lobifera" in Ageloupolos, 1967; De Coninck, 1975, 1977, 1980b; Eaton, 1976, Bujak et al., 1980, Van Couvering et al., 1981; Michoux, 1985; Nielsen et al., 1986; Murray et al., 1987); Norwegian-Greenland Sea (Manum, 1976; Manum et al., in press); Rockall Plateau (Costa and Downie, 1979b); Virginia, U.S. (Edwards, 1984); New Zealand (Wilson, 1984; Clowes and Morgans, 1985); and offshore eastern Canada (Williams and Bujak, 1977b; Barss et al., 1979; Ioakim, 1979). It also has been recorded from the Oligocene of Europe (Benedek, 1972; Benedek and Müller, 1974, 1976; Chateauneuf, 1980); Norwegian-Greenland Sea (Manum, 1976); northwestern China (Mao and Norris, 1984, 1988); Alabama, U.S. (Edwards, 1977); offshore eastern Canada (Williams and Bujak, 1977b; Barss et al., 1979); and the Nile Delta, Egypt (El-Beialy, 1988). A few Miocene records exist (a single specimen from the middle Miocene of Germany as " $P$. lobifera" in Gerlach, 1961; lower Miocene of Belgium in Benedek, 1980), 
although these may be attributed to reworking. Of those records having good stratigraphic control, the lowest occurrence appears to be from Bed R4 of the Røsnæes Clay of Denmark (Nielsen et al., 1986), which is correlated to lower Eocene Zone NP11 by Nielsen and HeilmannClausen (1988). Elsewhere, S. chlamydophora was reported as having a slightly higher lowest occurrence, within lower Eocene Zone NP12 (viz. Rockall Plateau, Zone NP12 in Costa and Downie, 1979b; southern England, in Bujak et al., 1980, correlated to lower Zone NP12 in Aubry, 1985; eastern U.S., Edwards, 1984, correlated to Zone NP12 in DiMarzio, 1984). A highest occurrence within the lower Oligocene, lower Zone NP23 (Benedek and Müller, 1974, 1976) is presently indicated for S. chlamydophora.

\section{Genus SVALBARDELLA Manum, 1960}

Remarks. Wrenn and Hart (1988) rejected the contention of Lindgren (1984) that Svalbardella Manum, 1960 was a subjective senior synonym of Palaeocystodinium Alberti, 1961. Wrenn and Hart considered that differences between these genera (namely overall shape and expression of paratabulation in addition to the archeopyle) are sufficiently stable within the species currently assigned to Palaeocystodinium and Svalbardella to justify maintaining both genera.

In the Northern Hemisphere, species referable to Svalbardella presently have been recorded from the upper Eocene (and lower Oligocene?) of Spitsbergen (Manum, 1960; Manum and Throndsen, 1986; and a species questionably referred to Svalbardella, M.J.H., unpubl. data); the lower Oligocene (Manum et al., in press) (and questionably middle Eocene through middle Miocene; Manum, 1976) of the NorwegianGreenland Sea; the lower to middle Eocene of the North Sea (Ioakim, 1979); the upper Eocene and lower Oligocene of the Labrador Sea (this study); the "middle" or upper Oligocene of offshore eastern Canada (Barss et al., 1979); and a questionable occurrence from the lower upper Oligocene of northwestern Germany (as Svalbardella cf. granulata in Benedek, 1972). The geographic range of these species suggests that they are indicators of cool or cold water.

\section{Svalbardella sp. cf. S. cooksoniae Manum, 1960}

Remarks. This species occurs rarely in Samples 105-647A-35R-1, $135-138 \mathrm{~cm}$, and $-30 \mathrm{R}-3,100-104 \mathrm{~cm}$ (upper Eocene to lowermost Oligocene) in Hole 647A. Specimens have an outline and fine irregular reticulation similar to $S$. cooksoniae and also have faint indication of a paracingulum and longitudinal lines on the horns. Ornament is not as pronounced as for the holotype of $S$. cooksoniae or for specimens assigned to S. cooksoniae in Manum and Throndsen (1986), nor was a parasulcus observed. For these reasons, we could not make a specific identification with certainty. S. cooksoniae has been recorded infrequently from the upper lower Eocene (upper Cuisian) to upper middle Eocene (Bartonian) (below an upper Eocene hiatus) in the North Sea (Ioakim, 1979, Table 3); from the middle or upper Oligocene of offshore eastern Canada (Barss et al., 1979); from the upper Eocene of DSDP Site 336, Norwegian Sea (Manum and Throndsen, 1986); from the lower Oligocene of ODP Site 643, Norwegian Sea (Manum et al., in press); and from Eocene or Oligocene strata (probable upper Eocene, according to Manum and Throndsen, 1986) at Sarsbukta, Spitsbergen (Manum, 1960; Manum and Throndsen, 1986).

\section{Svalbardella sp. 1}

(Pl. 2, Figs. 9,10)

Remarks. This species is represented by a single specimen (Sample 105-647A-19R, CC; lower Oligocene). It differs from Svalbardella sp. cf. $S$. cooksoniae in having a periphragmal surface ornament predominantly of low sinuous ridges $0.5 \mu \mathrm{m}$ wide that are longitudinally aligned. These may coalesce locally, but form a less distinct finely reticulate pattern than for $S$. sp. cf. $S$. cooksoniae. A faint paracingulum might be discernible on the dorsal surface.

\section{Svalbardella? sp. 2}

Remarks. This species is comparable in outline with the specimen illustrated as Svalbardella (Palaeocystodinium) spp. by Manum (1976, Pl. 5, Fig. 1 only) and may be conspecific with it. The ornament is similar to that of Svalbardella sp. 1, but much fainter. We could not distinguish the paracingulum with certainty. This species was recorded from Sample 105-647A-22R, CC, from the lower Oligocene.
Genus THALASSIPHORA Eisenack and Gocht, 1960 emend. Benedek and Gocht, 1981

Thalassiphora pelagica (Eisenack, 1954) Eisenack and Gocht, 1960

$$
\text { (P1. 9, Figs. 2, 3) }
$$

Remarks. This species occurs sporadically from the upper lower Eocene through to lower Oligocene in Samples 105-647A-70R-4, 42-45 cm, through -19 R, CC (Zones NP11 through NP23; Firth, this volume). Various morphotypes attributed by Gocht (1968) to an ontogenetic series within T. pelagica (see also Benedek and Gocht, 1981) were encountered with the typical morphotype (as illustrated in Pl. 9, Fig. 2) in some samples. A similar range of morphotypes was also reported by Brown and Downie (1984) from the Eocene of the Rockall Plateau. An extensive synonymy for $T$. pelagica is given by Sarjeant (1981). T. pelagica has a probable highest occurrence in the upper Oligocene, e.g., offshore eastern U.S., lower $G$. ciperoensis planktonic foraminiferal Zone $\equiv$ lower Zone NP25 in Stover (1977); northwestern Germany in Benedek (1972); New Zealand in Wilson (1984); Virginia, U.S. in Edwards (1984, correlated to Zone CP19 $\equiv$ Zones NP24/25 from DiMarzio, 1984); northwestern Italy, planktonic foraminiferal Zone P22 $\equiv$ lower Zone NP25 in Powell (1986b). We propose a range of Maestrichtian (following Williams and Bujak, 1985) to upper Oligocene (lower Zone NP25) for $T$. pelagica, with higher occurrences (e.g., lower Miocene Zone NN4/5, Mediter ranean Sea in Corradini, 1978; lower Miocene of northwestern Italy in Powell, 1986a; lower Miocene of offshore eastern U.S. in Stover, 1977; ar:d upper Miocene of Spain in Jan du Chêne, 1977) that are typically sporadic, pending verification.

Genus WETZELIELLA Eisenack, 1938 emend. Lentin and Williams, 1976

Wetzeliella symmetrica Weiler, 1956

Remarks. W. symmetrica occurs rarely in four samples from uppermost Eocene to lower Oligocene and has its highest appearance in Sample 105-647A-17R, CC (assigned to upper Zone NP23; Firth, this volume). W. symmetrica was first described from the "middle" Oligocene of Germany (Weiler, 1956) and other Oligocene reports of this species include those from from northwestern Germany (Zones NP22 and NP24 in Benedek and Müller, 1976), Virginia, U.S. (Edwards, 1984, correlated to Zone CP19 $\equiv \mathrm{NP24} / 25$ from DiMarzio, 1984), offshore eastern U.S. (persistently occurring in planktonic foraminiferal G. opima opima Zone $\equiv$ upper NP23/NP24, although occurring sporadically into the upper Oligocene and lower Miocene in Stover, 1977), and northwestern Italy (as $W$. sp. cf. $W$. articulata, Zone P21b $\equiv$ Zones NP24 or lower NP25 in Powell, 1986a). A comprehensive list of records is given in Sarjeant $(1983$, p. 107-108), who considered the established range for W. symmetrica as from lower Eocene to Pliocene, with earlier and later records, pending confirmation. However, Haq et al. (1987) proposed a highest occurrence for Wetzeliella species at the Oligocene/Miocene boundary, and Costa (1980) also found that Wetzeliella species have a useful top in the upper Oligocene of the North Sea. Therefore, based on the above records, we propose a range top for W. symmetrica within Zones NP24/ NP25? of the upper Oligocene. Costa (1985) indicated that W. symmetrica sensu stricto was restricted to the lower and "middle" Oligocene. We are inclined toward the view reflected in Costa's (1985) proposed range, i.e., that Eocene specimens assigned to W. symmetrica may be somewhat different from those of the Oligocene (as represented by the holotype). We thus propose a tentative lower range of lower Eocene? or lower Oligocene for W. symmetrica.

\section{DINOCYSTS OF UNCERTAIN GENERIC AFFINITY}

Dinocyst sp. D
(Pl. 11, Fig. 7)

Remarks. Specimens have a smooth-walled spherical central body and cylindrical processes that are distally closed. Distal margins bear tubules and hollow spines. Often, scattered hollow spines also occur along the process stem, particularly over the distal two-thirds of its length. The archeopyle may be epicystal, with a free operculum, and specimens (without opercula) have from 11 to about 13 processes. This species may be conspecific with the specimen of Homotryblium sp. A of Costa and Downie, 1979b, which, judging from the illustration, is an epicystal operculum with the process formula $3^{\prime}, 5^{\prime \prime}$. Homotryblium sp. A was recorded only from Zone NP14 sediments of DSDP Site 406, Rockall 
Plateau (Costa and Downie, 1979b, correlated from Müller, 1979). Dinocyst sp. D occurs in upper lower and middle? Eocene sediments in Hole 647A.

\section{Dinocyst sp. E}

Remarks. This species differs from Dinocyst sp. D in having narrower $(2.5-3.5 \mu \mathrm{m})$ and more numerous processes (approximately 24 to 28 ), although it may be similar in all other respects, including the nature of the processes.

\section{ACKNOWLEDGMENTS}

Financial support for this project was obtained from a Natural Sciences and Engineering Research Council of Canada operating grant to G. Norris and from the Department of Energy Mines and Resources Research Agreement Nos. 66, 96, and 195 to G. Norris and M. J. Head. We thank G. L. Williams and R. Fensome for their hospitality during a visit by M. J. Head to the Bedford Oceanographic Institute, Nova Scotia, in 1985; M. A. Kaminski (presently at Dalhousie University, Nova Scotia) for his hospitality during a visit by M. J. Head to Woods Hole Oceanographic Institution in 1986; S. B. Manum (University of Oslo) for making available to us a pre-publication copy of the Leg 104 palynological results; and G. L. Williams for useful comments about the manuscript. We are grateful to M. A. Kaminski for supplying some of the samples used in this study and to Juliet MacDonald (University of Toronto) for assistance with their processing. We thank Allan McColl (Royal Ontario Museum) for photographic assistance. We are especially grateful to S. P. Damassa and J. K. Lentin, who reviewed the manuscript and provided numerous helpful comments.

\section{REFERENCES}

Taxonomic references prior to 1985 are not comprehensively included here, and the reader is referred to Lentin and Williams (1985) for these.

Agelopoulos, J., 1967. Hystrichosphären, Dinoflagellaten und Foraminiferen aus dem eozänen Kieselton von Heiligenhafen, Holstein. Math.-Naturwiss. Fak. Eberhard-Karls-Univ. [Dissert.] Tübingen, 1-74, Pls. 1 through 14.

Ager, T. A., Edwards, L. E., and Oftedahl, O., 1986. Eocene palynomorphs from the Franklin buffs, Arctic slope, Northeast Alaska. Palynology, 10:243. [Abstract].

Archangelsky, S., and Fasola, A., 1971. Algunos elementos del paleomicroplancton del Terciario inferior de Patagonia (Argentina y Chile). Rev. Museo Plata (Nue. Ser.) Sec. Paleontol., 6(36):1-18.

Aubry, M.-P., 1985. Northwestern European Paleogene magnetostratigraphy, biostratigraphy, and paleogeography: calcareous nannofossil evidence. Geology, 13:198-202.

Aubry, M.-P., Hailwood, E. A., and Townsend, H. A., 1986. Magnetic and calcareous-nannofossil stratigraphy of the lower Palaeogene formations of the Hampshire and London basins. J. Geol. Soc. (London), 143:729-735.

Backman, J., 1984. Cenozoic calcareous nannofossil biostratigraphy from the northeastern Atlantic Ocean-Deep Sea Drilling Project Leg 81 . In Roberts, D. G., Schnitker, D., et al., Init. Repts. DSDP, 81: Washington (U.S. Govt. Printing Office), 403-428.

Barss, M. S., Bujak, J. P., and Williams, G. L., 1979. Palynological zonation and correlation of 67 wells, eastern Canada. Geol. Surv. Can. Pap., 78-24:1-117.

Benedek, P. N., 1972. Phytoplanktonten aus dem Mittel- und Oberoligozän von Tönisberg (Niederrheingebiet). Palaeontographica, Abt. B, 137:1-71, Pls. 1-16.

,1980. Vorläufige Ergebnisse der Phytoplankton-Untersuchungen aus dem nordwesteuropäischen Tertiärbecken. In Vinken, R., and Meyer, K.-J. (Eds.), The Northwest European Tertiary Basin: IGCP Project 124, Rept. 6:87-92.

Benedek, P. N., and Gocht, H., 1981. Thalassiphora pelagica (Dinoflagellata, Tertiär): electronenmikroskopische Untersuchung und Gedanken zur Paläobiologie. Palaeontographica, Abt. B, 180:39-64, Pls. 1-5.

Benedek, P. N., and Müller, C., 1974. Nannoplankton-PhytoplanktonKorrelation im Mittel- und Ober-Oligozän von NW-Deutschland. Neu. Jahrb. Geol. Paläontol. Monats., 7:385-397.
1976. Die Grenze Unter/Mittel-Oligozän am Doberg bei Bünde/Westfalen. I. Phyto-und Nannoplankton. Neu. Jahrb. Geol. Paläontol. Monats., 3:129-144.

Benedek, P. N., and Sarjeant, W.A.S., 1981. Dinoflagellate cysts from the middle and upper Oligocene of Tönisberg (Niederrheingebiet): a morphological and taxonomic restudy. Nova Hedwigia, 35:313-356, 6 pls.

Berggren, W. A., Kent, D. V., and Flynn, J. J., 1985. Palaeogene geochronology and chronostratigraphy. In Snelling, N. J. (Ed.), The Chronology of the Geological Record. Geol. Soc. (London) Mem., 10:141-195.

Biffi, U., and Grignani, D., 1983. Peridinioid dinoflagellate cysts from the Oligocene of the Niger Delta, Nigeria. Micropaleontology, 29(2): 126-145, Pls. 1-7.

Biffi, U., and Manum, S. B., 1988. Late Eocene-early Miocene dinoflagellate cyst stratigraphy from the Marche region (central Italy). Boll. Soc. Paleontol., Italiana, 27(2):163-212.

Brideaux, W. W., 1976. Taxonomic notes and illustrations of selected dinoflagellate cyst species from the Gulf Mobil Parsons N-10 well. Rept. Activities, Part B, Geol. Surv. Can. Pap., 76-1B:251-257.

Brown, S. and Downie, C., 1984. Dinoflagellate cyst biostratigraphy of Late Paleocene and early Eocene sediments from Holes 552, 553, and 555, Leg 81, Deep Sea Drilling Project (Rockall Plateau). In Roberts, D. G., Schnitker, D., et al., Init. Repts. DSDP, 81: Washington (U.S. Govt Printing Office), 565-579.

1985. Dinoflagellate cyst stratigraphy of Paleocene to Miocene sediments from the Goban Spur (Sites 548-550, Leg 80). In de Graciansky, P. C., Poag, C. W., et al., Init. Repts. DSDP, 81: Washington (U.S. Govt. Printing Office), 643-651.

Bujak, J. P., 1976. An evolutionary series of late Eocene dinoflagellate cysts from southern England. Mar. Micropaleontol., 1:101-117, Pls. $1-4$.

1979. Proposed phylogeny of the dinoflagellates Rhombodinium and Gochtodinium. Micropaleontology, 25:308-324, Pls. 1-3. 1984. Cenozoic dinoflagellate cysts and acritarchs from the Bering Sea and northern North Pacific, DSDP Leg 19. Micropalaeontology, 30(2):180-212, Pls. 1-4.

Bujak, J. P., and Davies, E. H., 1983. Modern and fossil Peridiniineae. Am. Assoc. Stratigr. Palynol. Contrib. Ser., 13:1-203, Pls. 1-12.

Bujak, J. P., and Matsuoka, K., 1986. Late Cenozoic dinoflagellate cyst zonation in the western and northern Pacific. Am. Assoc. Stratigr. Palynol. Contrib. Ser., 17:7-25, 3 pls.

Bujak, J. P., Downie, C., Eaton, G. L., and Williams, G. L., 1980. Dinoflagellate cysts and acritarchs from the Eocene of southern England. Palaeontol. Assoc., Spec. Pap. Palaeontol., 24:26-36.

Bujak, J. P., Davies, E. H., and Williams, G. L., 1987. Biostratigraphy of the Labrador and Baffin shelves: geological implications. Am. Assoc. Stratigr. Palynol. 20th Annu. Mtg. [Prog. and Abstr.], 28.

Bybell, L. M., 1975. Middle Eocene calcareous nannofossils at Little Stave Creek, Alabama. Tulane Stud. Geol. Paleontol., 11(4):117252.

Caro, Y., 1973. Contribution a la connaissance des dinoflagellés du Paléocène-Eocène inférieur des Pyrenées espagnoles. Rev, Español. Micropaleontol., 5:329-372, PIs. 1-5.

Chateauneuf, J.-J., 1979. Upper Eocene and Oligocene Dinophyceae of the Paris Basin (France). Proc., 4th Int. Palynol. Conf., Lucknow (1976-1977; 1979), 2:47-58.

1980. Palynostratigraphie et Paléoclimatologie de l'Eocène supérieur et de l'Oligocène du Bassin de Paris. Bur. Recherches Géol. Minières Mém., 116:1-360, Pls. 1-31.

Chateauneuf, J.-J., and Gruas-Cavagnetto, C., 1978. Les zones de Wetzeliellaceae (Dinophyceae) du bassin de Paris. Bull. Bur. Recherches Géol. Minières (deuxième sér.), Sec. IV(2):59-93, Pls. 1-5.

Clowes, C. D., 1985. Stoveracysta, a new gonyaulacacean dinoflagellate genus from the upper Eocene and lower Oligocene of New Zealand. Palynology, 9:27-35.

Clowes, C. D., and Morgans, H.E.G., 1984. Micropaleontology of the Runagan-Whaingaroan (Eocene-Oligocene) Totara Limestone. N.Z. Geol. Surv. Rec., 3:30-40.

Cookson, I. C., 1956. Additional microplankton from Australian late Mesozoic and Tertiary sediments. Austral. J. Mar. Freshwater Res., 7:183-191, Pls. 1-2.

1965. Cretaceous and Tertiary microplankton from southeastern Australia. Proc. R. Soc. Victoria, 78:85-93, Pls. 9-11. 
Cookson, I. C., and Eisenack, A., 1965. Microplankton from the Browns Creek Clays, S.W. Victoria. Proc. R. Soc. Victoria, 79:119-131, Pls. $11-15$.

Corradini, D., 1978. Dinoflagellate cysts in deep-sea cores from DSDP Site 372, East Menorca Rise. In Ross, D. A., Neprochnov, Y. P., et al., Init. Repts. DSDP, 42: Washington (U.S. Govt. Printing Office), $1225-1230$

Costa, L. I., 1980. Neogene dinocyst stratigraphy in the northern North Sea. Fifth Int. Palynol. Conf., Cambridge, 1980 [Abstract], 92.

(Ed.), 1985. A regional dinoflagellate zonation for the Tertiary of Northwest Europe and its continental shelf. Norwegian Pet. Direct. Bull., 4 (draft copy seen only).

Costa, L. I, and Downie, C., 1976. The distribution of the dinoflagellate Wetzeliella in the Palaeogene of northwestern Europe. Paleontology, 19:591-614, Pl. 92.

1979a. The Wetzeliellaceae; Palaeogene dinoflagellates. Proc. 4th Int. Palynol. Conf., Lucknow (1976-1977), 2:34-46.

1979b. Cenozoic dinocyst stratigraphy of Sites 403 to 406 (Rockall Plateau), IPOD, Leg 48. In Montadert, L., Roberts, D. G., et al., Init. Repts. DSDP, 48: Washington (U.S. Govt. Printing Office), 513-529.

Damassa, S. P., 1979. Eocene dinoflagellates from the Coastal Belt of the Franciscan Complex, northern California. J. Paleontol., 53:815840 , Pls. $1-8$.

De Coninck, J., 1975. Microfossiles a paroi organique de l'Yprésien du Bassin belge. Serv. Géol. Belgique Prof. Pap., 12:1-151, Pls. 1-22. 1977. Organic-walled microfossils from the Eocene of the Woensdrecht borehole, southern Netherlands. Med. Rijks Geol. Dienst, Nieu. Ser., 28:34-63, Pls. 1-8.

$1980 \mathrm{a}$. Organic-walled microfossils in the clay of Ieper in the Overijse borehole. Bull. Soc. Belge Géol., 89(4):201-215.

$1980 \mathrm{~b}$. Espèces indicatrices de microfossiles a paroi organique de depots de L'Yprésien supèrieur et du Lutetien dans le sondage de Kallo. Bull. Soc. Belge Géol., 89(4):309-317.

De Coninck, J., De Decker, M., Heinzelin, J., and Willems, W., 1981. L'age des faunes D'Erquelinnes. Bull. Soc. Belge Géol., 90(2):121154, Pls. 1-5.

De Coninck, J., Geets, S., and Willems, W., 1983. The Mont-Heribu Member: base of the Ieper Formation in the Belgian Basin. Tertiary Res., 5(2):83-104, Pls. 1-3.

DiMarzio, J. D., 1984. Calcareous nannofossils from the Piney Point Formation, Pamunkey River, Virginia. In Ward, L. W., and Kraft, K. (Eds.), Stratigraphy and Paleontology of the Outcropping Tertiary Beds in the Pamunkey River Region, Central Virginia Coastal Plain (Guidebook, Atlantic Coastal Plain Geol. Assoc., 1984 Field Trip). Atlantic Coastal Plain Geol. Assoc., 111-116.

D'Iorio, M. A., 1986. Integration of foraminiferal and dinoflagellate data sets in quantitative stratigraphy of the Grand Banks and Labrador Shelf. Bull. Can. Pet. Geol., 34(2):277-283.

Downie, C., Hussain, M. A., and Williams, G. L., 1971. Dinoflagellate cyst and acritarch associations in the Paleogene of southern England. Geoscience Man, 3:29-35.

Drugg, W. S., 1970. Some new genera, species, and combinations of phytoplankton from the lower Tertiary of the Gulf Coast, U.S.A. Proc. North Am. Paleontol. Conv. Chicago, 1969, G:809-843.

Eaton, G. L., 1971. A morphogenetic series of dinoflagellate cysts from the Bracklesham beds of the Isle of Wight, Hampshire, England. In Farinacci, A. (Ed.), Proc. 2nd Planktonic Conf. Rome, 1970 (Edizioni Technoscienza), 1:355-379, Pls. 1-4.

1976. Dinoflagellate cysts from the Bracklesham beds (Eocene) of the Isle of Wight, southern England. Bull. Br. Mus. Nat. Hist. (Geol.), 26:227-332, Pls. 1-21.

El-Beialy, S. Y., 1988. Palynostratigraphy of late Tertiary sediments in Kafr El Dawar Well No. 1, Nile Delta, Egypt. Rev. Micropaléontol., 30(4):249-260.

Edwards, L. E., 1977. Range charts as chronostratigraphic hypotheses, with applications to Tertiary dinoflagellates [Ph.D. dissert.]. Univ. of California, Riverside.

1984. Dinocysts of the Tertiary Piney Point and Old Church Formations, Pamunkey River area, Virginia. In Ward, L. W., and Kraft, K. (Eds.), Stratigraphy and Paleontology of the Outcropping Tertiary Beds in the Pamunkey River Region, Central Virginia Coastal Plain (Guidebook, Atlantic Coastal Plain Geol. Assoc., 1984 Field Trip. Atlantic Coastal Plain Geol. Assoc., 124-134, 2 pls.
1986. Late Cenozoic dinoflagellate cysts from South Carolina, U.S.A. Am. Assoc. Stratigr. Palynol. Contrib. Ser., 17:47-58.

Edwards, L. E., and Bebout, J. W., 1981. Emendation of Phthanoperidinium Drugg and Loeblich, 1967, and a description of $P$. brooksi sp. nov. from the Eocene of the Mid-Atlantic outer continental shelf. Palynology, 5:29-41, Pls. 1-2.

Edwards, L. E., Goodman, D. K., and Witmer, R. J., 1984. Lower Tertiary (Pamunkey Group) dinoflagellate biostratigraphy, Potomac River area, Virginia and Maryland. In Frederiksen, N. O., and Krafft, K. (Eds.), Cretaceous and Tertiary Stratigraphy, Paleontology, and Structure, southwestern Maryland and northeast Virginia. AASP Field Trip Vol. Guide Book, 137-152.

Eisenack, A., 1954. Mikrofossilien aus Phosphoriten des samländischen Unteroligozäns und über die Einheitlichkeit der Hystrichosphaerideen. Palaeontographica Abt. A, 105:49-95, Pls. 7-12.

Evitt, W. R., 1961. Observations on the morphology of fossil dinoflagellates. Micropaleontology, 7:385-420, Pls. 1-9.

1985. Sporopollenin Dinoflagellate Cysts: Their Morphology and Interpretation: (AASP Foundation), 1-333.

Fechner, G. C., and Mohr, B. A., 1988. Early Eocene spores, pollen, and microplankton assemblages from Fehmarn Island, northern Germany. In Collinson, M. E. (Ed.), Plants and Their Palaeoecology: Examples from the Last 80 Million Years. Tertiary Res., 9(1-4):147168.

Frederiksen, N. O., 1980. Sporomorphs from the Jackson Group (upper Eocene) and adjacent strata of Mississippi and western Alabama. U.S. Geol. Surv. Prof. Pap., 1084:1-75.

Gerlach, E., 1961. Mikrofossilien aus dem Oligozän und Miozän Nordwestdeutschlands, unter besonderer Berücksichtigung der Hystrichosphären und Dinoflagellaten. Neue Jahrb. Geol. Paläontol. Abh., 112:143-228, Pls. 25-29.

Gibson, T. G., Andrews, G. W., Bybell, L. M., Fredericksen, N.O. Hansen, T., Hazel, J. E., McLean, D. M., Witmer, R. J., and Van Nieuwenhuise, D. S., 1980. Biostratigraphy of the Tertiary strata of the core. In Geology of the Oak Grove Core: (Virginia Div. Miner. Resources), Publ. 20(2):14-30.

Gibson, T. G., and Bybell, L. M., 1984. Foraminifers and calcareous nannofossils of Tertiary strata in Maryland and Virginia: a summary. In Frederiksen, N. O., and Krafft, K. (Eds.), Cretaceous and Tertiary Stratigraphy, Paleontology, and Structure, southwestern Maryland and northeast Virginia. AASP Field Trip Vol. Guide Book, 181-189.

Gocht, H., 1955. Rhombodinium und Dracodinium, zwei neue Dinoflagellaten-Gattungen aus dem norddeutschen Tertiär. Neue Jahrb. Geol. Paläontol. Monat., 84-92.

1968. Zur Morphologie und Ontogenie von Thalassiphora (Dinoflagellata). Palaeontographica Abt. A, 129:149-150, Pls. 2527.

1969. Formengemeinschaften alttertiären Mikroplanktons aus Bohrproben des Erdöfeldes Meckelfeld bei Hamburg. Palaeontographica Abt. B, 126:1-100, Pls. 1-11.

Goodman, D. K., 1979. Dinoflagellate "communities" from the lower Eocene Nanjemoy Formation of Maryland, U.S.A. Palynology, 3: 169-190.

1984. Dinoflagellate biostratigraphy of the Nanjemoy Formation at Popes Creek, Southeastern Maryland. In Frederiksen, N. O., and Krafft, K. (Eds.), Cretaceous and Tertiary Stratigraphy, Paleontology, and Structure, Southwestern Maryland and Northeast Virginia. AASP Field Trip Vol. Guide Book, 153-161.

Goodman D. K., and Ford, L. N., 1983. Preliminary dinoflagellate biostratigraphy for the middle Eocene to lower Oligocene from the southwest Atlantic Ocean. In Ludwig, W. J., Krashenninikov, V. A., et al., Init. Repts. DSDP, 71: Washington (U.S. Govt. Printing Office), 859-877, Pls. 1-8.

Gruas-Cavagnetto, C., 1970. Dinophyceae, Acritarcha, et pollens de la formation de Varengeville (Cuisien, Seine-Maritime). Rev. Micropaleontol., 13(2);69-79.

Hailwood, E. A., Bock, W., Costa, L., Dupeuble, P. A., Müller, C., and Schnitker, D., 1979. Chronology and biostratigraphy of northeast Atlantic sediments, DSDP Leg 48. In Montadert, L., Roberts, D. G., et al., Init. Repts. DSDP, 48: Washington (U.S. Govt. Printing Office), 1119-1141.

Haq, B. U., Hardenbol, J., and Vail, P., 1987. Chronology of fluctuating sea levels since the Triassic. Science, 235:1156-1166. 
Harland, R., 1983. Distribution maps of Recent dinoflagellate cysts in bottom sediments from the North Atlantic Ocean and adjacent seas. Paleontology, 26:321-387.

Head, M. J., 1984. A palynological investigation of Tertiary strata at Renardoden, W. Spitsbergen. Sixth Int. Palynol. Conf., Calgary [Abstracts], 61 .

Head, M. J., Norris, G. L., and ODP Leg 105 Shipboard Party, 1986. Paleogene palynology of ODP Site 647, Leg 105, Labrador Seapreliminary results. AASP/CIMP Joint Annu. Mtg., New York [Program and Abstracts], 16.

Heilmann-Clausen, C., 1982. The Paleocene-Eocene boundary in Denmark. Newsl. Stratigr., 11(2):55-63.

1985. Dinoflagellate stratigraphy of the uppermost Danian to Ypresian in the Viborg 1 borehole, central Jylland, Denmark. Dan. Geol. Unders. Ser. A, 7:1-69.

Hooyberghs, H.J.F., 1980. Present status in the biostratigraphy by means of nannoplankton and planktonic foraminifera in the Tertiary of Belgium. In Vinken, R., and Meyer, K.-J. (Eds.), The Northwest European Tertiary Basin. Int. Geol. Correl. Progr., 124(6):106-118.

Ioakim, C., 1979. Etude comparative des dinoflagellés du Tertiaire infèrieur de la Mer du Labrador et de la Mer Nord [Ph.D. dissert.]. LUniversité Pierre et Marie Curie, Paris, 1-204.

Ioannides, N. S., and Colin, J. P., 1977. Palynology at Sites 358, 356, 355, DSDP Leg 39, Southwestern Atlantic Ocean. In Supko, P. R., Perch-Nielsen, K., et al., Init. Repts. DSDP, 39: Washington (U.S. Govt. Printing Office), 855-897.

Ioannides, N. S., and McIntyre, D. J., 1980. A preliminary palynological study of the Caribou Hills outcrop section along the Mackenzie River, District of Mackenzie. In Report of Activities, Part B. Geol. Surv. Can. Pap., 80(1A):197-208.

Islam, M. A., 1982. Archeopyle structure in the fossil dinoflagellate Phthanoperidinium. Rev. Paleobot. Palynol., 36:305-316, Pls. 1,2.

1983a. Dinoflagellate cysts from the Eocene cliff sections of the Isle of Sheppey, southeast England. Rev. Micropaléontol., 25: 231-250, Pls. 1-4.

1983b. Dinoflagellate cyst taxonomy and biostratigraphy of the Eocene Bracklesham Group in southern England. Micropaleontology, 29:328-353, Pls. 1-4.

1983c. Dinoflagellate cysts from the Eocene of the London and Hampshire basins, southern England. Palynology, 7:71-92, Pls. $1-4$.

1984. A study of early Eocene palaeoenvironments in the Isle of Sheppey, as determined from microplankton assemblage composition. Tertiary Res., 6(1):11-21.

Jain, K. P., and Garg, R., 1982. Revision of some dinoflagellate cysts from Meghalaya, India. J. Paleontol. Soc. India, 27:68-70.

Jan du Chêne, R., 1977. Etude palynologique du Miocène supérieur Andalou (Espagne). Rev. Española Micropaleontol., 9:97-114, Pls. 1,2 .

Lentin, J. K., and Williams, G. L., 1985. Fossil dinoflagellates: index to genera and species, 1985 edition. Can. Tech. Rept. Hydrogr. Ocean Sci., 60:1-451.

Liengjarern, M., Costa, L., and Downie, C., 1980. Dinoflagellate cysts from the upper Eocene-lower Oligocene of the Isle of Wight. Palaeontology, 23:475-499.

Lindgren, S., 1984. Acid resistant peridinoid dinoflagellates from the Maastrichtian of Trelleborg, southern Sweden. Stockholm Contrib. Geol., 39(6):145-201.

Lott, G. K., Knox, R. W.O'B., Harland, R., and Hughes, M. J., 1983. The stratigraphy of Palaeogene sediments in a cored borehole off the coast of northeast Yorkshire. Rept. Inst. Geol. Sci. (U.K.), 83(9):1-8.

Manum, S. B., 1960. Some dinoflagellates and hystrichosphaerids from the Lower Tertiary of Spitsbergen. Nytt Magasin Botanikk, 8:17-26, $1 \mathrm{pl}$.

1976. Dinocysts in Tertiary Norwegian-Greenland Sea sediments (Deep Sea Drilling Project Leg 38), with observations on palynomorphs and palynodebris in relation to environment. In Talwani, M., Udintsev, G., et al., Init. Repts. DSDP, 38: Washington (U.S. Govt. Printing Office), 897-919, 6 pls.

1980. Provisional range chart selected dinoflagellate cysts, NW Europe. In Vinken, R., and Meyer, K.-J., (Eds.), The Northwest European Tertiary Basin. IGCP Project 124, 6:86.

Manum, S. B., and Throndsen, T., 1986. Age of Tertiary formations on Spitsbergen. Polar Res., 4:103-131, 6 pls.
Manum, S. B., Boulter, M. C., Gunnarsdottir, H., Rangnes, K., and Scholze, A., in press. Palynology of the Eocene to Miocene sedimentary sequence of ODP Leg 104 (Norwegian Sea). In Eldholm, O., Thiede, J., et al., Proc. ODP, Init. Repts., 104: College Station, TX (Ocean Drilling Program).

McCave, I. N., and Tucholke, B. E., 1986. Deep current-controlled sedimentation in the western North Atlantic. In Voght, P. R., and Tucholke, B. E. (Eds.), The Geology of North America, Vol. M, The Western North Atlantic Region. Geol. Soc. Am., 451-468.

McLean, H., and Hein, J. R., 1984. Paleogene geology and chronology of southwestern Umnak Island, Aleutian Islands, Alaska. Can. J. Earth Sci., 21(2):171-180.

McNeil, D. H., Ioannides, N. S., and Dixon, J., 1982. Geology and biostratigraphy of the Dome Gulf et al. Ukalerk C-50 Well, Beaufort Sea. Geol. Surv. Can. Pap., 80(32):1-17, Pls. 1-4.

Mao, S., and Norris, G., 1984. Lower Tertiary dinoflagellate stratigraphy and paleoecology, western Talimu Basin, Xinjiang Province, northwest China. Proc. 6th Int. Palynol. Conf., Calgary [Abstracts], 99.

1988. Late Cretaceous-early Tertiary dinoflagellates and acritarchs from the Kashi Area, Tarim Basin, Xinjiang Province, China. R. Ontario Mus., Life Sci. Contrib., 150:1-93.

Martini, E., 1971. Standard Tertiary and Quaternary calcareous nannoplankton zonation. Proc., 2nd Planktonic Conf., Rome 1970, 2: 739-785.

Martini, E., and Müller, C., 1986. Current Tertiary and Quaternary calcareous nannoplankton stratigraphy and correlations. Newsl. Stratigr., 16(2):99-112.

Martini, E., and Moorkens, T., 1970. The type locality of the sands of Grimmertingen and calcareous nannoplankton from the lower Tongrian. Bull. Soc. Belge Géol., Palélontol., Hydrol., 78:111-130.

Matsuoka, K., Bujak, J. P., and Shimazaki, T., 1987. Late Cenozoic dinoflagellate cyst biostratigraphy from the west coast of North Japan. Micropaleontology, 33(3):214-229.

Michoux, D., 1985. Palynostratigraphie de L'Eocene de Montfort-enChalosse (Landes, France). Rev. Micropaleontol., 28(2):138-152, Pls. $1-3$.

Miller, K. G., and Tucholke, B. E., 1983. Development of Cenozoic abyssal circulation south of the Greenland-Scotland Ridge. In Bott, M.H.P. et al. (Eds.), Structure and Development of the GreenlandScotland Ridge; New Methods and Concepts: New York (Plenum Press), NATO Conf. Ser. IV, Vol. 8, 549-591.

Miller, K. G., Fairbanks, R. G., and Mountain, G. S., 1987. Tertiary oxygen isotope synthesis, sea level history, and continental margin erosion. Paleoceanography, 2:1-19.

Morgenroth, P., 1966a. Mikrofossilien und Konkretionen des nordwesteuropäischen Untereozäns. Palaeontographica Abt. B, 199:1-53, Pls. 1-11.

1966b. Neue in organischer Substanz erhaltene Mikroossilien des Oligozäns. Neue Jahrb. Geol. Paläontol., 127:1-12, Pls. 1, 2.

Morton, A. C., Backman, J., and Harland, R., 1983. A reassessment of the stratigraphy of DSDP Hole 117A, Rockall Plateau: implications for the Paleocene/Eocene boundary in NW Europe. Newsl. Stratigr., 12(2):104-111

Mudie, P. J., 1985. Palynology of the CESAR cores. In Jackson, H. R. et al. (Eds.), Initial Geological Report on CESAR-The Canadian Expedition To Study the Alpha Ridge, Arctic Ocean. Geol. Surv. Can. Pap., 84-22(11):149-174, Pls. 11-1-11-6.

1986. Palynology and dinoflagellate biostratigraphy of Deep Sea Drilling Project Leg 94, Sites 607 and 611, North Atlantic Ocean. In Ruddiman, W. F., Kidd, R. B., Thomas, E., et al., Init. Repts. DSDP, 94: Washington (U.S. Govt. Printing Office), 785-812.

Müller, C., 1979. Calcareous nannofossils from the North Atlantic (Leg 48). In Montadert, L., Roberts, D. G., et al., Init. Repts. DSDP, 48: Washington (U.S. Govt. Printing Office), 589-639.

1985. Biostratigraphic and paleoenvironmental interpretation of the Goban Spur region based on a study of calcareous nannoplankton. In de Gracianski, P. C., Poag, C. W., et al., Init. Repts. $D S D P, 80$ (Pt. 1): Washington (U.S. Govt. Printing Office), 573599.

Murray, J. W., Robinson, J. E., Gallagher, L. T., Eaton, G. L., and Tocher, B. A., 1987. Palaeogene. In Lord, A. R., and Brown, P. R. (Eds.), Mesozoic and Cenozoic Stratigraphical Micropaleontology of the Dorset Coast and Isle of Wight, Southern England. Br. Mi- 
cropaleontol. Soc., Guide Book 1:150-183 (Field Guide for the 20th European Micropalaeontological Colloquium).

Nielson, O. B., Baumann, J., Zhang, D., Heilmann-Clausen, C., and Larsen, G., 1986. The Tertiary section of borehole D.G.I. 83101, Osterrenden, Store Baelt, Denmark. In Møller, J. T. (Ed.), TwentyFive Years of Geology in Aarhus. Geol. Inst., Aarhus Univ., 24:235253.

Nielsen, O. B., and Heilmann-Clausen, C., 1988. Palaeogene volcanism: the sedimentary record in Denmark. In Morton, A. C., and Parson, L. M. (Eds.), Early Tertiary Volcanism and the Opening of the N.E. Atlantic. Geol. Soc. (London) Spec. Publ., 39:395-405.

Norris, G., 1986. Systematic and stratigraphic palynology of Eocene to Pliocene strata in the Imperial Nuktak C-22 Well, Mackenzie Delta Region, District of Mackenzie, N.W.T. Geol. Surv. Can. Bull., 340: 1-89.

Okada, H., and Bukry, D., 1980. Supplementary modification and introduction of code numbers to the low-latitude coccolith biostratigraphic zonation (Bukry, 1973, 1975). Mar. Micropaleontol., 5:321325 .

Owen, H. G., 1983. Atlas of Continental Displacement: 200 Million Years to the Present: Cambridge (Cambridge Univ. Press), 1-159.

Perch-Nielsen, K., 1985. Cenozoic calcareous nannofossils. In Bolli, H. M., Saunders, J. B., and Perch-Nielsen, K. (Eds.), Plankton Stratigraphy: Cambridge (Cambridge Univ. Press), 427-554.

Poag, C. W., 1987. The New Jersey Transect: stratigraphic framework and depositional history of a sediment-rich passive margin. In Poag, C. W., Watts, A. B., et al., Init. Repts. DSDP, 95: Washington (U.S. Govt. Printing Office), 763-817.

Powell, A. J., 1986a. Latest Palaeogene and earliest Neogene dinoflagellate cysts from the Lemme section, northwest Italy. AASP Contrib. Ser., 17:83-104.

$1986 \mathrm{~b}$. A dinoflagellate cyst biozonation for the late Oligocene to middle Miocene succession of the Langhe region, northwest Italy. AASP Contrib. Ser., 17:105-128.

Rauscher, R., and Schuler, M., 1988. Les dinokystes, des témoins d'influences marines dans le Paléogène d'Alsace. Bull. Centr. Recherches Exploration-Production Elf-Aquitaine, 12(1):405-425.

Regali, M. da S. P., Uesugui, N., and Santos, A. da S. S., 1974. Palinologia dos sedimentos meso-cenozóicos do Brasil (II). Bol. Téc. Petrobras, Riô de Janeiro, 17(4):263-300, Pls. 1-25.

Roberts, D. G., Montadert, L., and Searle, R. C., 1979. The western Rockall Plateau: stratigraphy and structural evolution. In Montadert, L., Roberts, D. G., et al., Init. Repts. DSDP, 48: Washington (U.S. Govt. Printing Office), 1061-1088.

Rolle, F., 1985. Late Cretaceous-Tertiary sediments offshore central West Greenland: lithostratigraphy, sedimentary evolution, and petroleum potential. Can. J. Earth Sci., 22:1001-1019.

Sarjeant, W.A.S., 1981. A restudy of some dinoflagellate cyst holotypes in the University of Kiel Collections II. The Eocene holotypes of Barbara Klumpp (1953), with a revision of the genus Cordosphaeridium Eisenack, 1963. Meyniana, 33:97-132, Pls. 1-6.

1983. A restudy of some dinoflagellate cyst holotypes in the University of Kiel Collections IV. The Oligocene and Miocene holotypes of Dorothea Maier (1959). Meyniana, 35:85-137, Pls. 1-7.

1984. Restudy of some dinoflagellate cysts from the Oligocene and Miocene of Germany. J. Micropalaeontol., 3(2):73-94, Pls. $1-4$.

Snyder, S. W., and Waters, V. J., 1985. Cenozoic planktonic foraminiferal biostratigraphy of the Goban Spur region, Deep Sea Drilling Project Leg 80. In Gracianski, P. C. de, Poag, C. W., et al., Init. Repts. DSDP, 80 (Pt.1): Washington (U.S. Govt. Printing Office), 439-461.

Soper, N. J., and Costa, L. I., 1978. Palynological evidence for the age of Tertiary basalts and post-basaltic sediments at Kap Dalton, central east Greenland. Rapp. Grønlands Geol. Unders., 80:123-127.

Soper, N. J., Downie, C., Higgins, A. C., and Costa, L. I., 1976a. Biostratigraphic ages of Tertiary basalts on the East Greenland continental margin and their relationship to plate separation in the northeast Atlantic. Earth Planet. Sci. Lett., 32:149-157.

Soper, N. J., Higgins, A. C., Downie, C., Matthews, D. W., and Brown, P. E., 1976b. Late Cretaceous-early Tertiary stratigraphy of the Kangerdlugssuaq area, East Greenland and the age of opening of the northeast Atlantic. J. Geol. Soc. (London), 132:85-104.

Srivastava, S. P., Arthur, M., et al., 1987. Proc. ODP, Init. Repts., 105: College Station, TX (Ocean Drilling Program).
Stover, L. E., 1973. Palaeocene and Eocene species of Deflandrea (Dinophyceae) in Victorian coastal and offshore basins, Australia. Geol. Soc. Austral., 4:167-188, 5 pls.

1975. Observations on some Australian Eocene dinoflagellates. Geoscience and Man, 11:5-45, Pls. 1-3.

1977. Oligocene and early Miocene dinoflagellates from Atlantic Hole 5/5B, Blake Plateau. AASP Contrib. Ser., 5(A):66-89, Pls. 1-3.

Stover, L. E., and Evitt, W. R., 1978. Analyses of Pre-Pleistocene Organic-Walled Dinoflagellates: Stanford (Stanford Univ. Publications, Geol. Sci.), 15:1-300.

Stover, L. E., Williams, G. L., and Eaton, G. L., 1988. Morphology and stratigraphy of the Paleogene dinoflagellate genus Areosphaeridium Eaton, 1971. Proc. 7th Int. Palynol. Conf., Brisbane [Abstracts], 157.

Townsend, H. A., and Hailwood, E. A., 1985. Magnetostratigraphic correlation of Palaeogene sediments in the Hampshire and London basins, southern U.K. J. Geol. Soc., 142(6):957-983.

Van Couvering, J. A., Aubry, M.-P., Berggren, W. A., Bujak, J. P., Naeser, C. W., and Wieser, T., 1981. The terminal Eocene event and the Polish connection. Palaeogeogr., Palaeoclimatol., Palaeoecol., 36:321-362.

Wall, D., and Dale, B., 1973. Paleosalinity relationships of dinoflagellates in the late Quaternary of the Black Sea-a summary. Geoscience and Man, 7:95-102.

Weiler, H., 1956. Uber einen Fund von Dinoflagellaten, Coccolithophoriden, und Hystrichosphaerideen im Tertiär des Rheintales. Neue Jahrb. Geol. Palälontol., Abh., 104:129-147.

Weyns, W., 1970. Dinophycées et acritarches des "Sables de Grimmertingen" dans leur localité-type, et les problèmes stratigraphiques du Tongrien. Bull. Soc. Belge Géol., Paléontol., Hydrol., 79(3-4):247268.

Williams, G. L., 1975. Dinoflagellate and spore stratigrsphy of the Mesozoic-Cenozoic, offshore eastern Canada. Geol. Surv. Can. Pap., 74-30, 2:107-161.

1978. Palynological biostratigraphy, Deep Sea Drilling Project, Sites 367 and 370. In Lancelot, Y., Seibold, E., et al., Init. Repts. DSDP, 41: Washington (U.S. Govt. Printing Office), 783815 , Pls. $1-8$.

Williams, G. L., and Brideaux, W. W., 1975. Palynologic analyses of upper Mesozoic and Cenozoic rocks of the Grand Banks, Atlantic continental margin. Geol. Surv. Can. Bull., 236:1-163.

Williams, G. L., and Bujak, J. P., 1977a. Distribution patterns of some North Atlantic Cenozoic Dinoflagellate cysts. Mar. Micropaleontol., 2:223-233.

1977b. Cenozoic palynostratigraphy of offshore eastern Canada. AASP Contrib. Ser., 5(A):14-47, 5 pls.

1985. Mesozoic and Cenozoic dinoflagellates. In Bolli, H. M., Saunders, J. B., and Perch-Nielsen, K. (Eds.), Plankton Stratigraphy: Cambridge (Cambridge Univ. Press), 847-864.

Williams, G. L., and Downie, C., 1966. Wetzeliella from the London Clay. In Davey, R. J., Downie, C., Sarjeant, W.A.S., and Williams, G. L., Studies on Mesozoic and Cainozoic Dinoflagellate Cysts. Bull. Br. Mus. (Nat. Hist.), Geol. Supp., 3:82-198.

Wilson, G. J., 1982. Eocene and Oligocene dinoflagellates from the Oamaru area, North Otago, N.Z. In Wilson, G. J. (Ed.), Abstracts of Unpublished New Zealand Geological Survey Reports on Fossil Dinoflagellates, 1981-1982. New Zealand Geol. Surv. Rept., PAL 52:18. 1984. New Zealand late Jurassic to Eocene dinoflagellate biostratigraphy: a summary. Newsl. Stratigr., 13(12):104-117.

Wise, S. W., Jr., 1983. Mesozoic and Cenozoic calcareous nannofossils recovered by Deep Sea Drilling Project Leg 71 in the Falkland Plateau Region, southwest Atlantic Ocean. In Ludwig, W. J., Krashenninikov, V. A., et al., Init. Repts. DSDP, 71: Washington (U.S. Govt. Printing Office), 481-550.

Wrenn, J. H., and Kokinos, J. P., 1986. Preliminary comments on Miocene through Pleistocene dinoflagellate cysts from De Soto Canyon, Gulf of Mexico. AASP Contrib. Ser., 17:169-225.

Wrenn, J. H., and Hart, G. F., 1988. Paleogene dinoflagellate cyst biostratigraphy Seymour Island, Antarctica. Geol. Soc. Am. Mem., 169:321-447.

Date of initial receipt: 11 July 1988

Date of acceptance: 3 February 1989

Ms 105B-178 


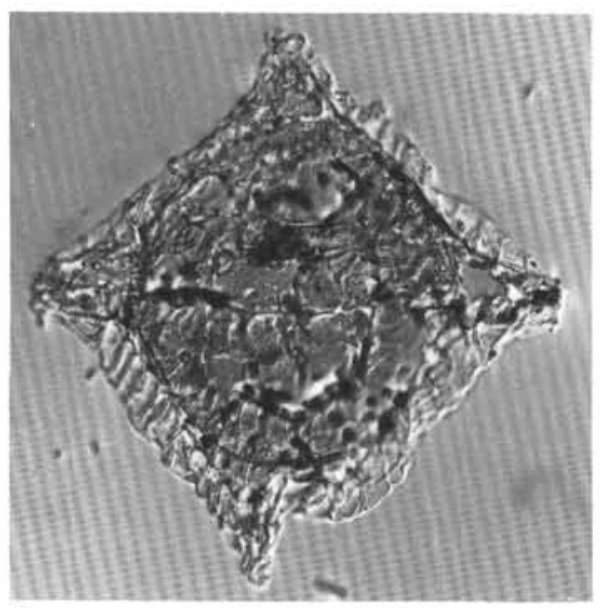

1

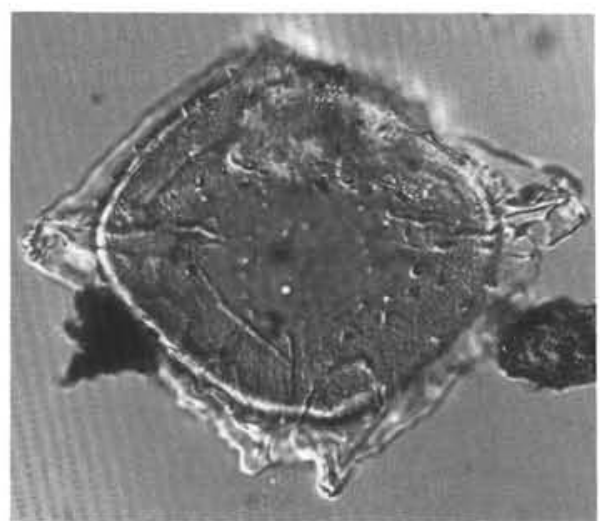

4

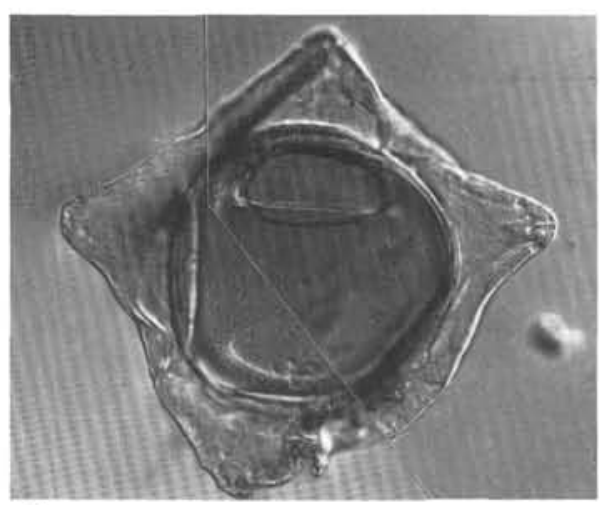
7

Plate 1. (1,2,4-7,9, IC; 3,8, BF) 1. Kisselovia coleothrypta. Sample 105-647A-68R-1, 129-132 cm (K2)D32/0; width, $121 \mu \mathrm{m}$ (vv., mf.). 2. Kisselovia crassoramosa. Sample 105-647A-68R-1, 129-132 cm (Kl)Ml5/l; width, $120 \mu \mathrm{m}$ (dv., ds.). 3. Kisselovia edwardsii sensu Caro, 1973 . Sample 105-647A-65R-1, 117-121 cm (2)M12/4; width, $102 \mu \mathrm{m}$ (vv., ds.). 4, 5. Gochtodinium spinulum. Sample 105-647A-52R-4, 25-28 cm (2)E35/0; width, $126 \mu \mathrm{m}$ (4, vv., vs.; 5, vv., ds.) 6. Dracodinium? sp. cf. D.? condylos. Sample 105-647A-69R, CC (2)M20/2; width, $94 \mu \mathrm{m}$ (vv., mf.). 7. Rhombodinium? sp. A. Sample 105-647A-68R-2, 76-79 cm (K1)T31/2; periphragm length, $146 \mu \mathrm{m}$ (vv., mf., split focus; note 4 to 8 rounded fenestrations, about $2-3 \mu \mathrm{m}$ dia. at ends of each horn). 8. Rhombodinium? sp. C. Sample 105-647A-67R-4, 23-26 cm (K1)L37/0; width, 120 $\mu \mathrm{m}$ (vv., mf.). 9. Rhombodinium? sp. B. Sample $105-647 \mathrm{~A}-70 \mathrm{R}-4,42-45 \mathrm{~cm}$ (4)H10/0; width, $114 \mu \mathrm{m}$ (vv., ds.). 


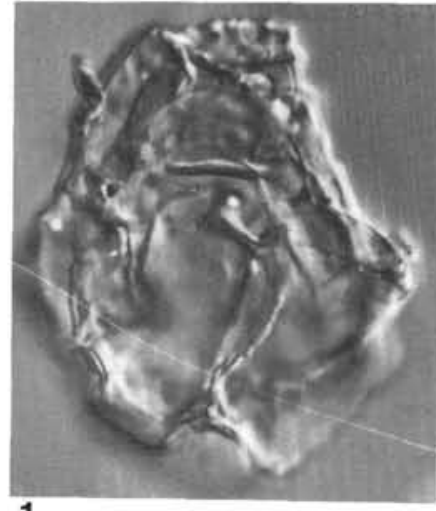

1

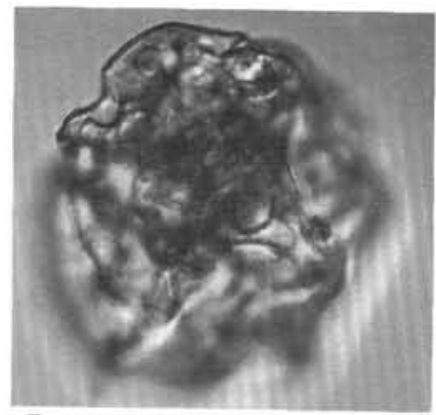

5

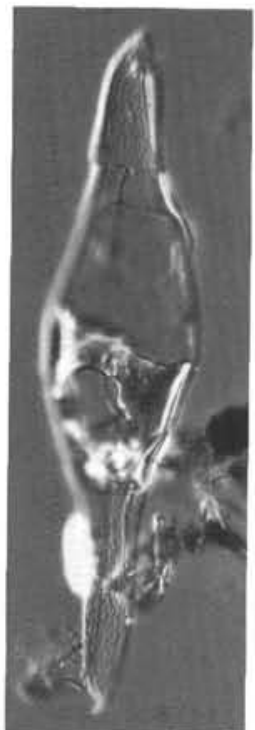

9

10

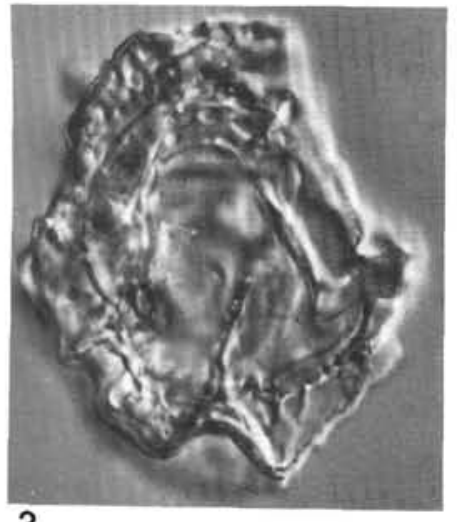

2

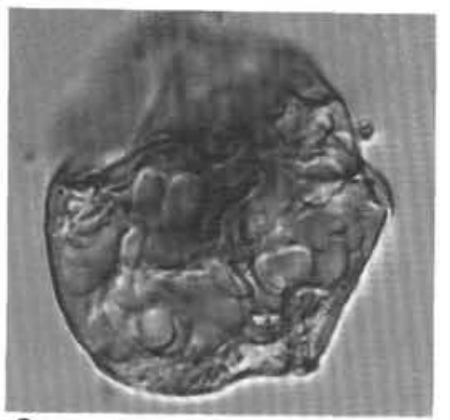

6

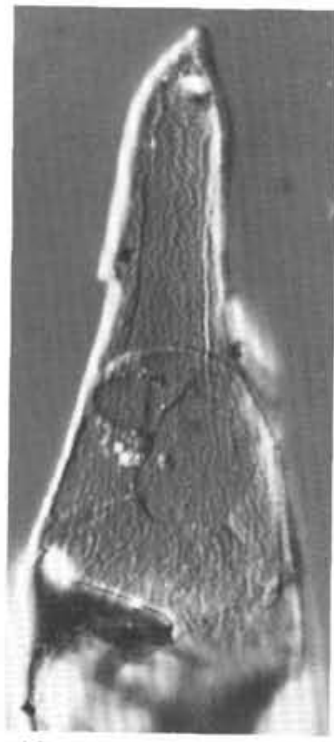

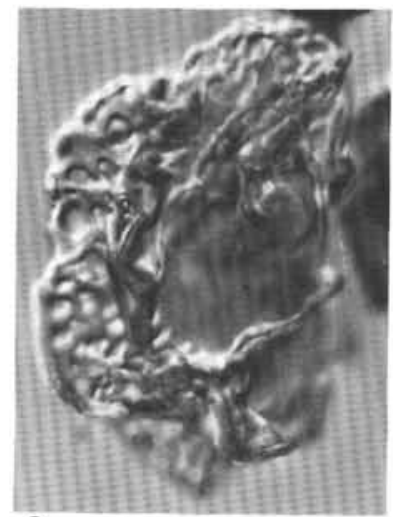

3

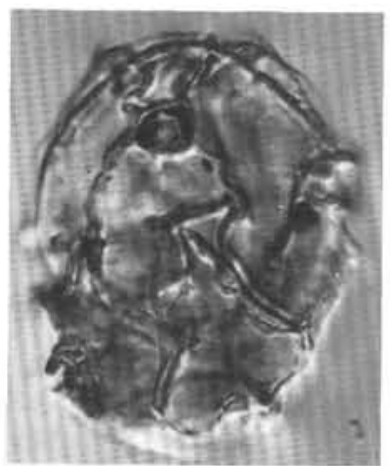

7

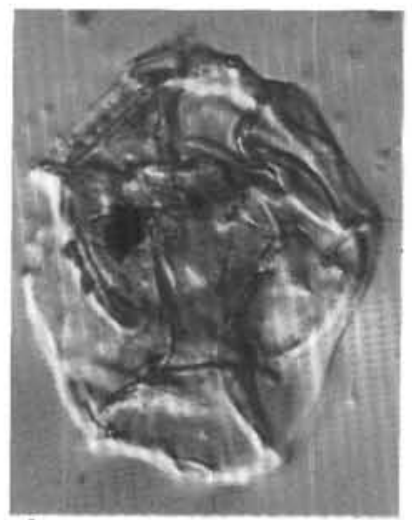

4

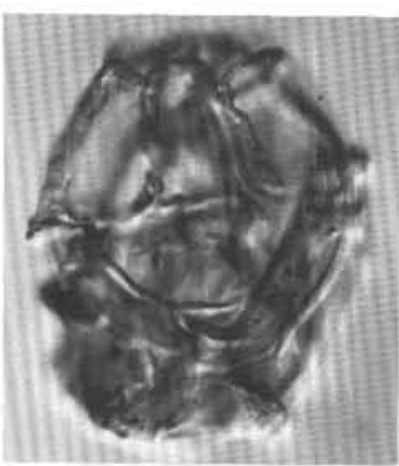

8

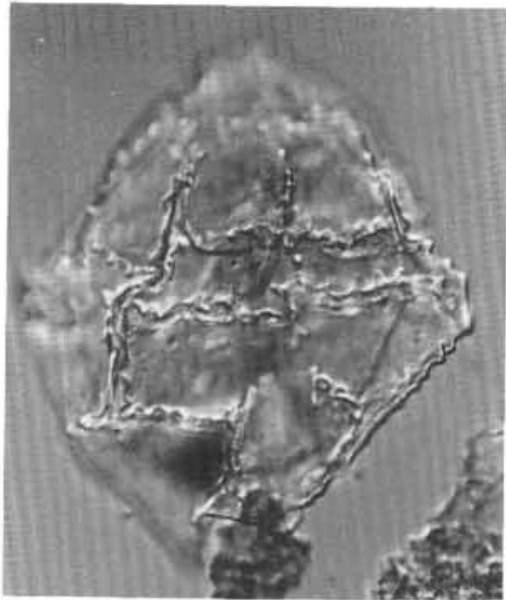

11

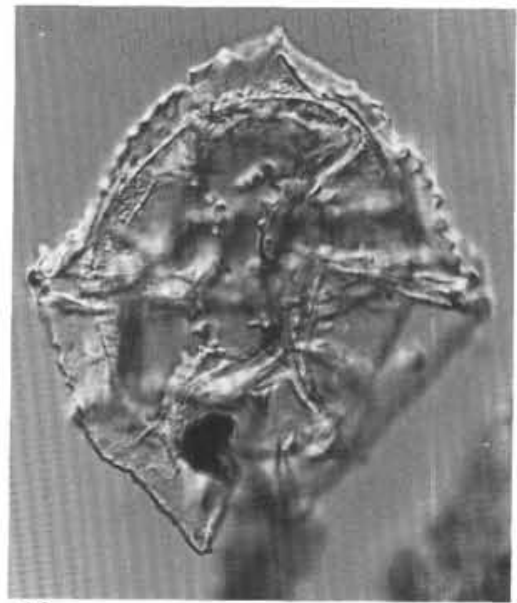

12

Plate 2. (all figs. IC) 1-3. Hystrichosphaeropsis sp. B. Note perforate periphragm. 1,2 Sample 105-674A-64R, CC (1)L17/3; max. length, 55 $\mu \mathrm{m}$. (1, left lat. v., left lat. s.; 2, left lv., rt. ls.). 3, Sample 105-647A-64R-3, 88-91 cm (1)K49/2; max. length, $58 \mu$ m lat. v., mf.). 4, 7, 8. Hystrichosphaeropsis sp. A. 4, Sample 105-647A-64R, CC (1)P11/0; max. length, $53 \mu \mathrm{m}$ (dv., ds.). 7,8, Sample 105-647A-64R, CC (1)L18/3; max. length, 51 $\mu \mathrm{m}$ (7, vv., vs.; 8, vv., ds.). 5, 6. Dinocyst sp. B. Note fenestrate/perforate periphragm, possible v. thin endocyst? Sample 105-647A-32R, CC (1)G43/4; max dia., $54 \mu \mathrm{m}$ (5,6 uncert. v.;5, lf., 6, hf.). 9,10. Svalbardella sp. 1. Sample 105-647A-19R, CC (1)T29/0; length, 168 $\mu \mathrm{m}(9, \mathrm{vv}$. , ds.; 10, vv., vs., at higher mag.). 11, 12. Wilsonidium tabulatum. Sample 105-647A-61R, CC (4)O10/0; max. width, $91 \mu \mathrm{m}$ (11, dv., ds.; 12, dv., vs.). 


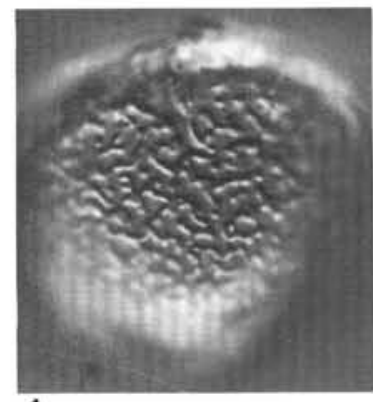

1

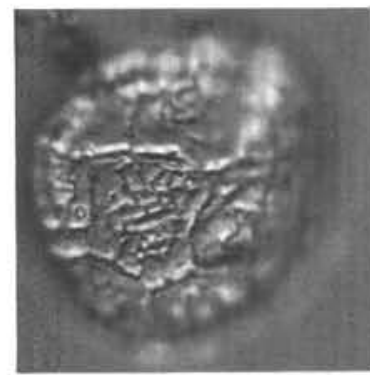

5

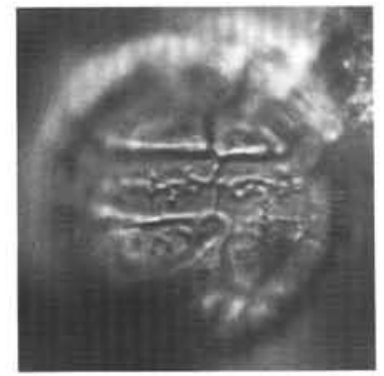

9

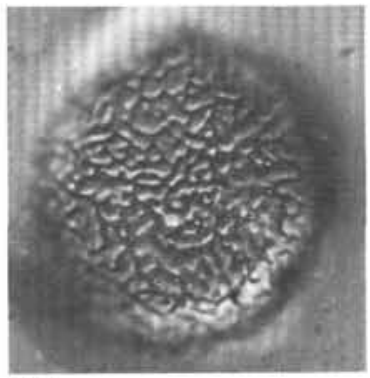

13

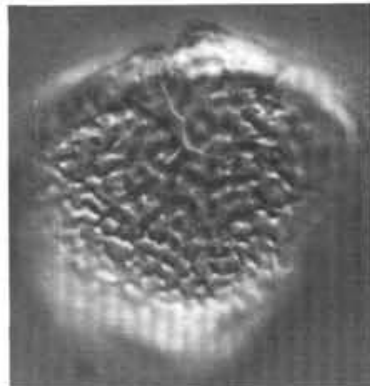

2

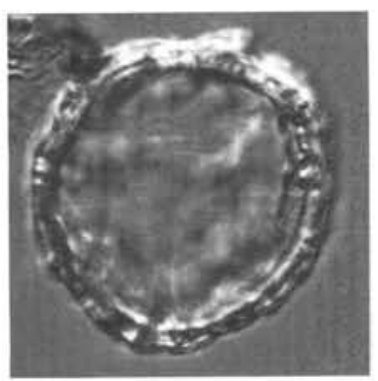

6

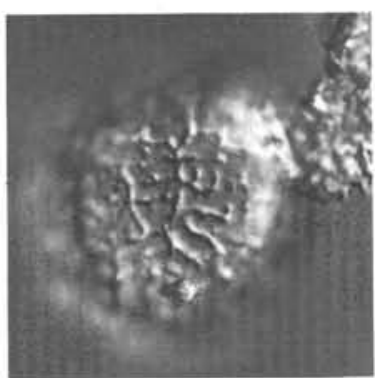

10

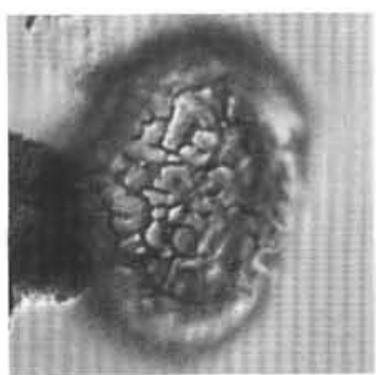

14

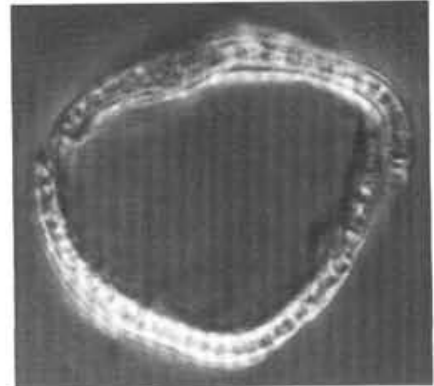

3

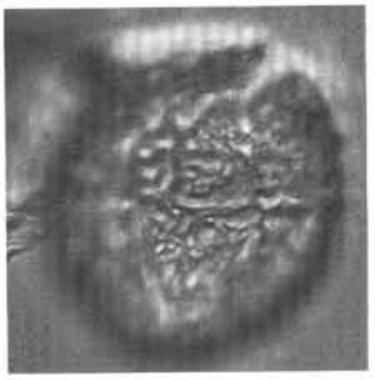

7

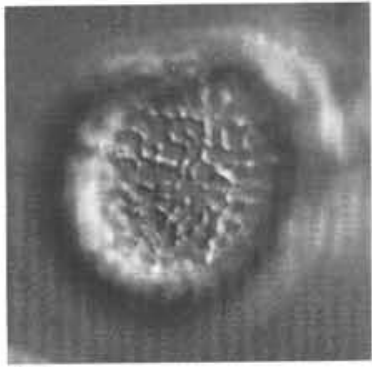

11

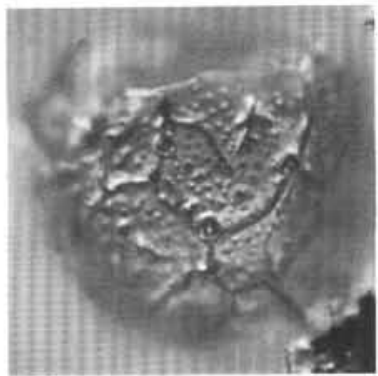

15

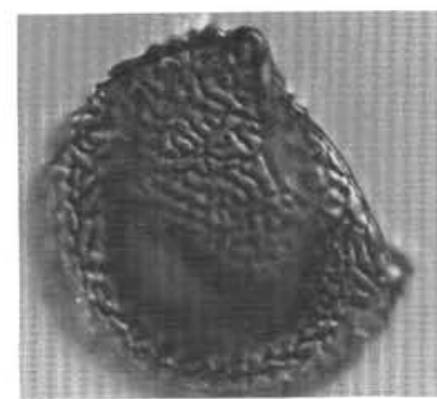

4

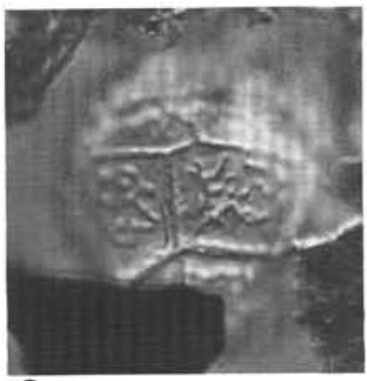

8

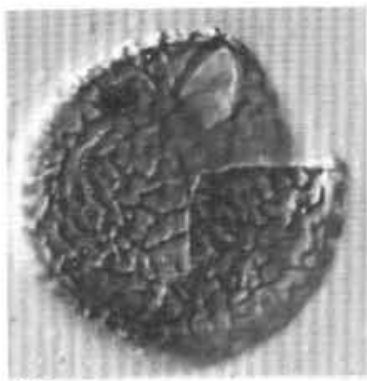

12

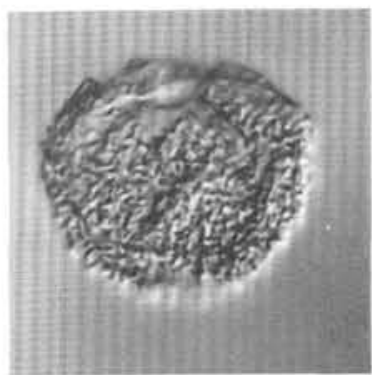

16

Plate 3. (all figs. IC) 1-3. Elytrocysta sp. Goodman and Ford, 1983. Sample 105-647A-24R-2, 142-145 cm (6)K46/0; max. dia., 41 $\mu \mathrm{m}$ (1-3, subap.v.: 1, subap.s.; 2, lrf.; 3, mf.). Note attached operculum and accessory suture in 1,2. 4, 12, 13. Corrudinium sp. 1. 4, Sample 105-647A-65R-1, $117-121 \mathrm{~cm}$ (1)J43/0; max. dia., $40 \mu \mathrm{m}$ (rt. lat. v.?, ls.). 12, Sample 105-647A-65R-1, 117-121 cm (1)H45/0; max. dia., $34 \mu \mathrm{m}$ (sub dv., sub ds.). 13 , Sample 105-647A-51R, CC (1)V53/1; max. dia., $36 \mu \mathrm{m}$ (antap. v., antap s.). 5-9. Histiocysta spp. of Goodman and Ford, 1983. 5-7, Sample 105647A-50R, CC (1)U35/4; max. dia. $35 \mu \mathrm{m}$ (5-7 lat. v., 5, us., 6, mf., 7, 1s.). Specimen has attached apical operculum. 8,9, Sample 105-647A-25R, CC (1)U12/0; max. dia., $33 \mu \mathrm{m}$ (8,9, lat. v., 8, us., 9, ls.). 10, 11. Elytrocysta sp. A. Sample 105-647A-50R, CC (1)N20/1; max. dia., 29 $\mu \mathrm{m}$ (lat. v., 10, us., 11, 1s.). 14. Corrudinium sp. 2. Sample 105-647A-63R-1, 105-108 cm (2)R42/0; max. dia., $34 \mu$ m (antap. v., antap. s.). Note weak paratabulation. 15. Corrudinium incompositum. Sample 105-647A-51R, CC (1)W23/2; max. dia., $37 \mu \mathrm{m}$ (left lat. v., left lat. s.). 16. Corrudinium sp. 3. Sample 105-647A-63R-1, 105-108 cm (2)P37/3; max. dia., $29 \mu \mathrm{m}$ (lat. v.?, us.). 


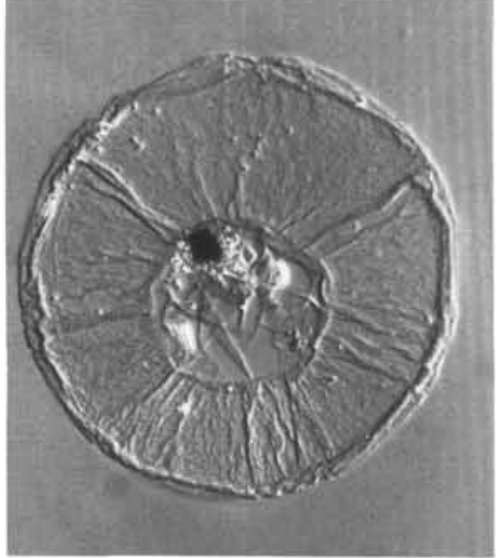

1

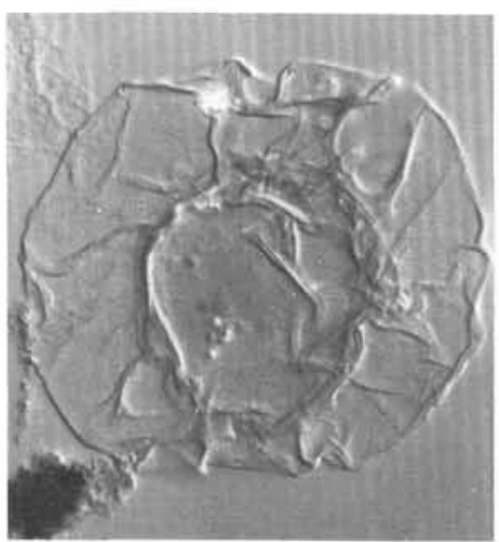

4

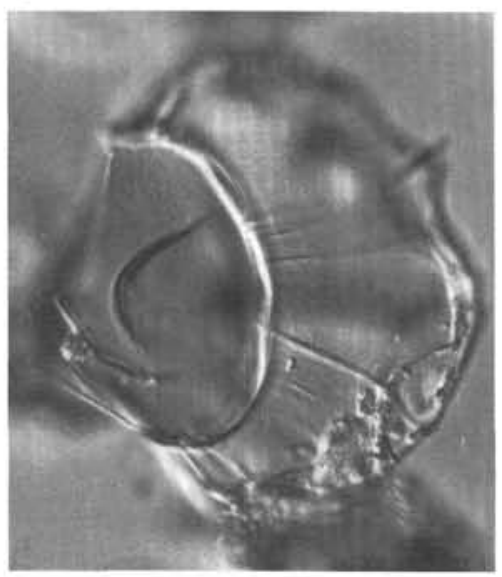

7

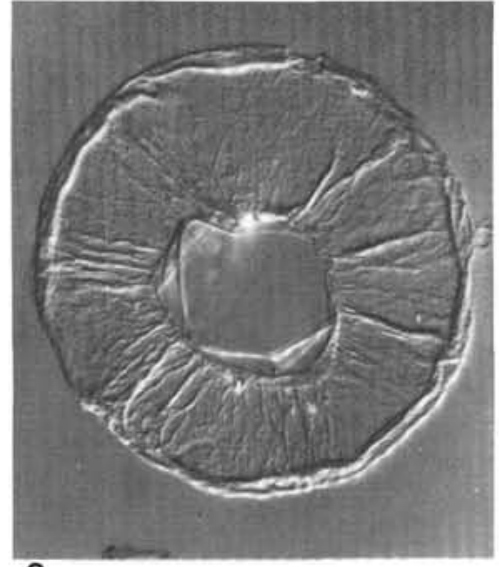

2

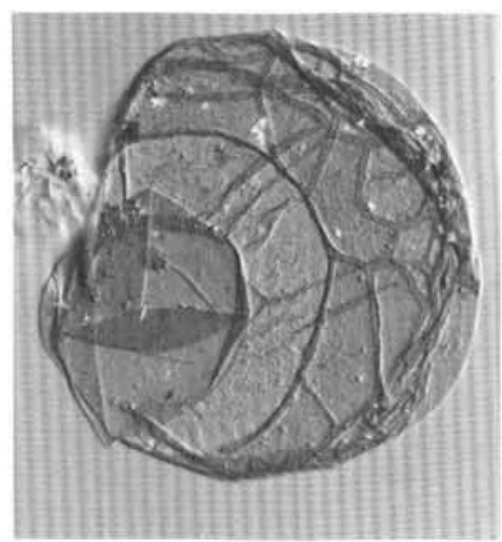

5

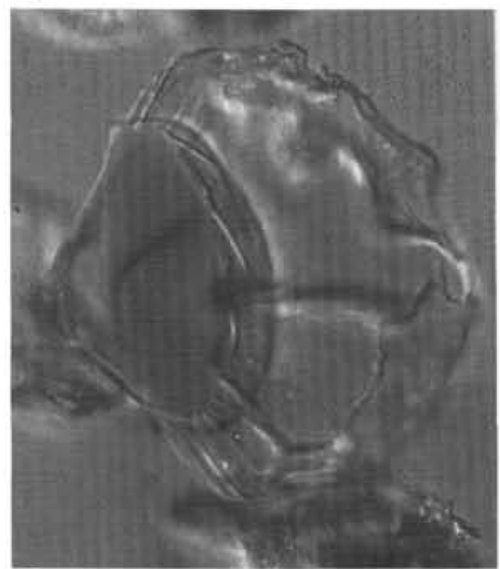

8

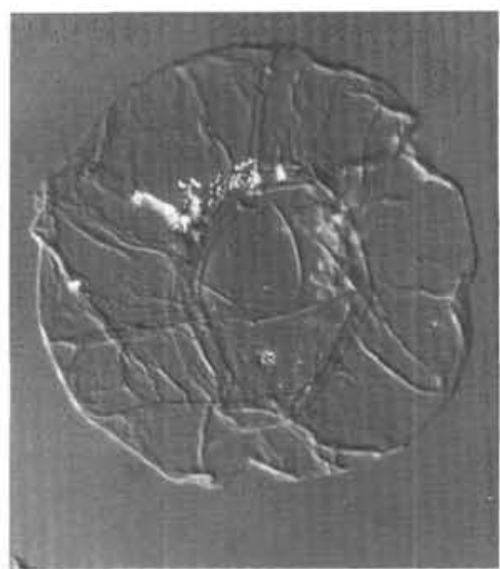

3

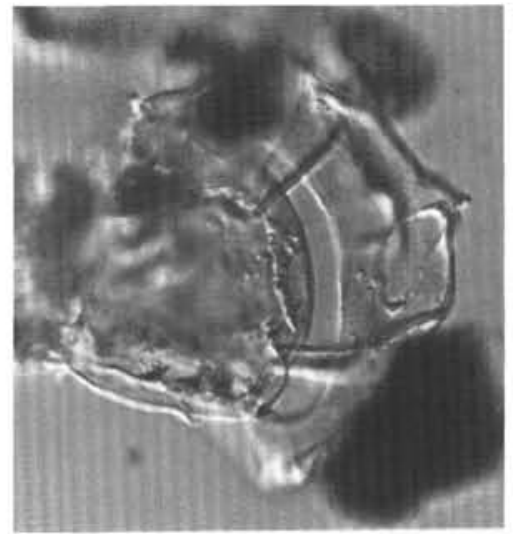

6

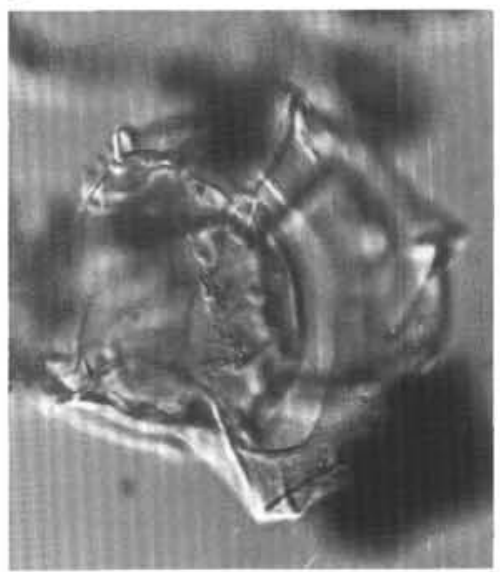

9

Plate 4. (all figs. IC) 1, 2. Dinocyst sp. C (archeopyle precingular?, periphragm expanded equatorially? Note weak paratabulation on periphragm). 1, Sample 105-647A-15R, CC (4)R45/0; $66 \mu$ m (ap.?, v., us.). 2, Sample 105-647A-15R, CC (4)F25/3; max. dia., $69 \mu$ m (antap. v., antap. s.). 3, 4. Invertocysta? sp. 3. Sample 105-647A-15R, CC (4)K52/3; max. dia., $69 \mu \mathrm{m}$ (uncert. v., us.). 4, Sample 105-647A-15R, CC (4)M55/2; max. dia., $69 \mu \mathrm{m}$ (uncert. v., us.). 5. Gelatia inflata. Sample 105-647A-17R, CC (1)S15/2; max. dia., $70 \mu \mathrm{m}$ (ap. v., ap. s.). 6,9. Lophocysta sp. 2 (faint lines on endocyst indicate paracingulum; a large, elongate fenestration occurs on left lat. surface of periphragm). Sample 105-647A-35R-1, 135-138 $\mathrm{cm}(\mathrm{J} 51 / 1)$; max. length, $66 \mu \mathrm{m}$ (6, rt. lat. v., left lat. s.; 9, rt. lat. v., lrf.). 7, 8. Lophocysta sp. 1 (note absence of fenestrations in periphragm). Sample 105-647A-24R-2, 142-145 cm (1)Q46/4; max. length, $69 \mu \mathrm{m}$ (7, rt. lat. v., left lat. s.; 8, rt. lat. v., rt lat. s.). 


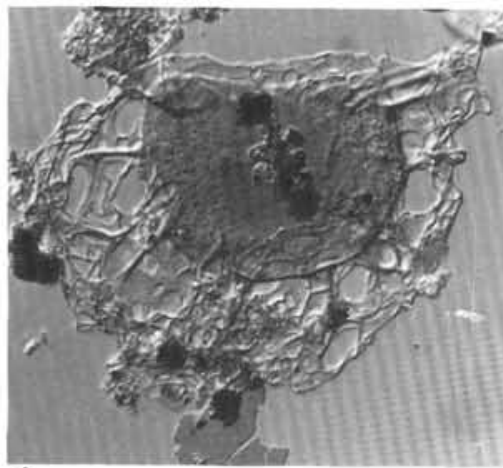

1

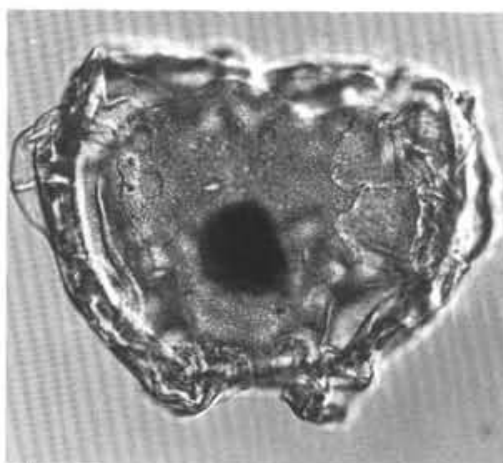

4

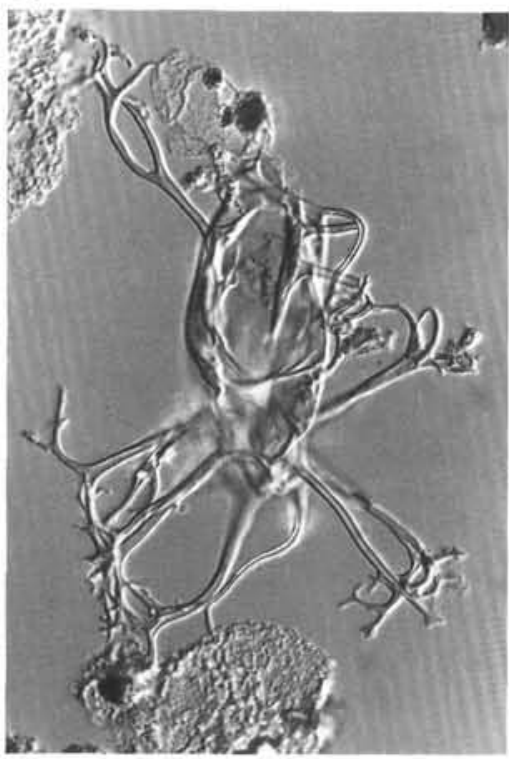

7

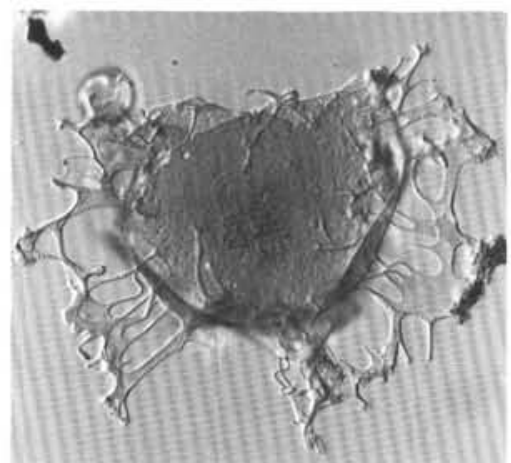

2

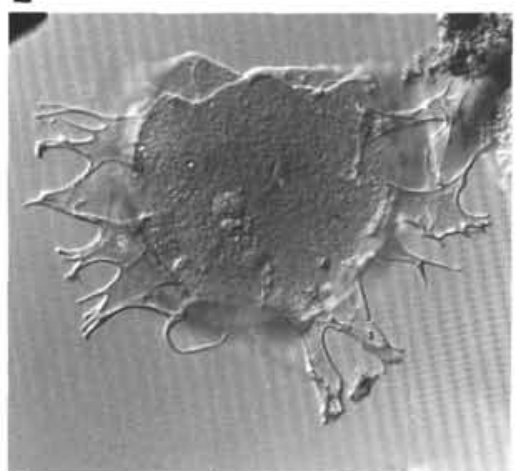

5

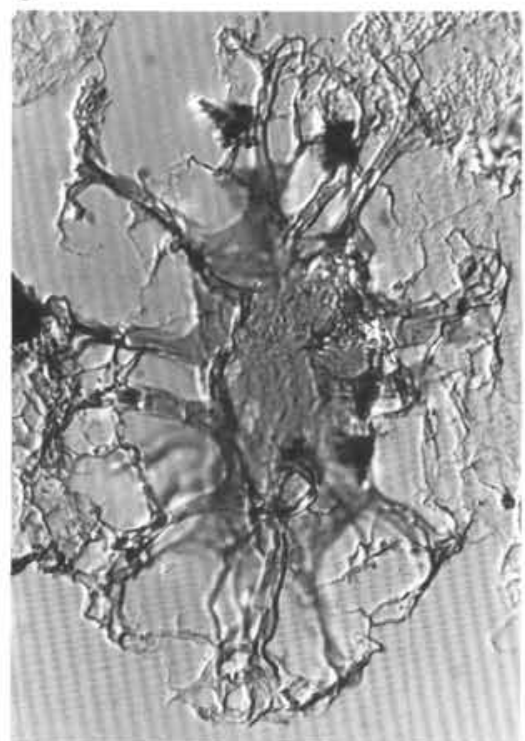

8

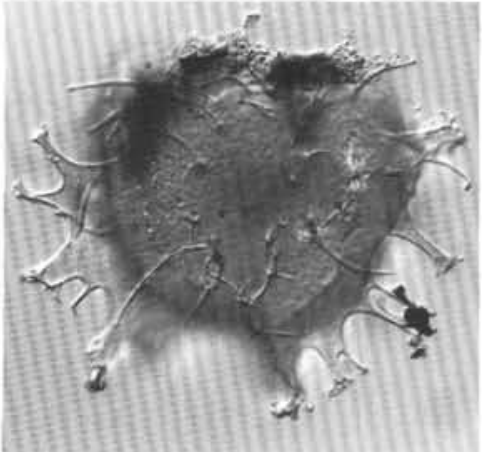

3

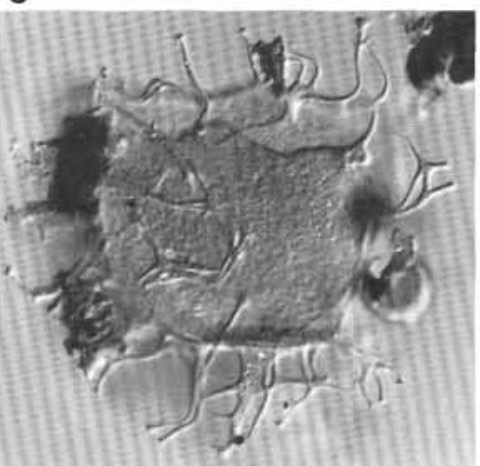

6

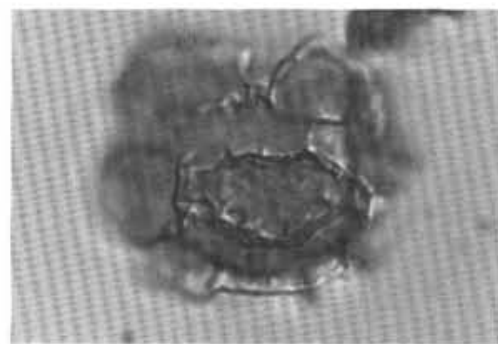

9

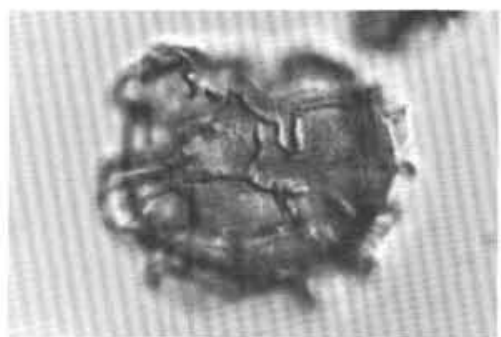

10

Plate 5. (all figs. IC) 1. Glaphyrocysta semitecta. Sample 105-647A-32R, CC (1)P22/4; endocyst max. dia., $64 \mu \mathrm{m}$ (dv., mf.) 2. Glaphryocysta sp. A. Sample 105-647A-22R, CC (1)M53/2; endocyst max. dia., $86 \mu \mathrm{m}$ (dv.?, ds.?). 3, 6. Chiropteridium mespilanum. 3, Sample 105-647A-15R, CC (4)R23/2; endocyst max. dia., $81 \mu \mathrm{m}$ (vv., vs.). 6, Sample 105-647A-19R, CC (5)D15/4; endocyst max. dia., $72 \mu \mathrm{m}$ (vv., vs.). 4. Membranophoridium aspinatum. Sample 105-647A-19R, CC (5)T52/0; periphragm max. dia., $112 \mu \mathrm{m}$ (dv., vs.). 5. Chiropteridium lobospinosum. Sample 105647A-15R, CC (4)T30/0; endocyst max. dia., $78 \mu \mathrm{m}$ (vv., vs.). 7. Distatodinium paradoxum sensu Gocht $(1969$, Figs. 5,6) $=$ Microsphaeridium ancistroides?. Sample 105-647A-22R, CC (1)R39/3; endocyst length, $66 \mu \mathrm{m}$ (lat. v., us.). 8. Distatodinium sp. cf. D. craterum. Sample 105-647A-30R-3, 100-104 cm (1)H16/4; endocyst length, $57 \mu \mathrm{m}$ (lat. v., us.). 9, 10. Hemiplacophora semilunifera. Sample 105-647A-35R, CC (1)K31/2; max. dia. (incl. crests), $42 \mu \mathrm{m}$ ( 9 , dv., ds.; 10, dv., vs.). 


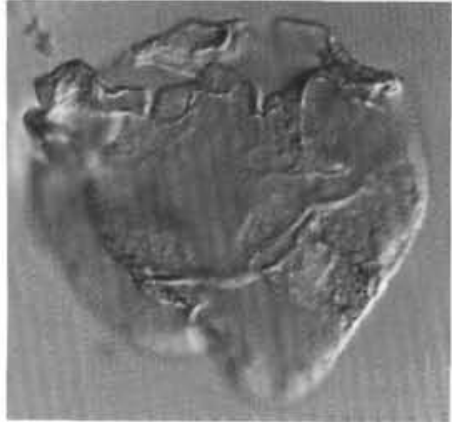

1

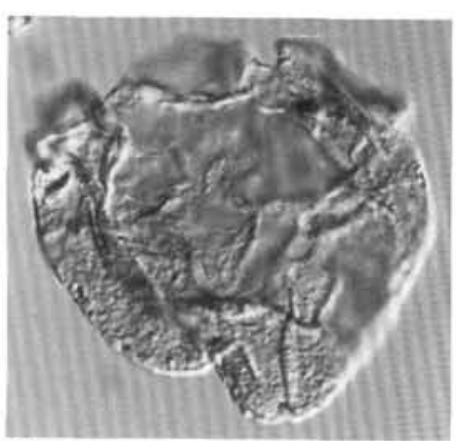

5

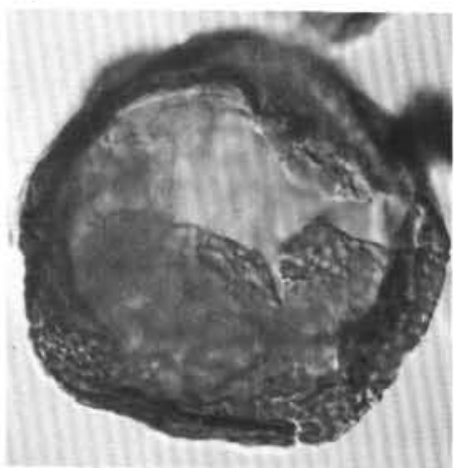

9

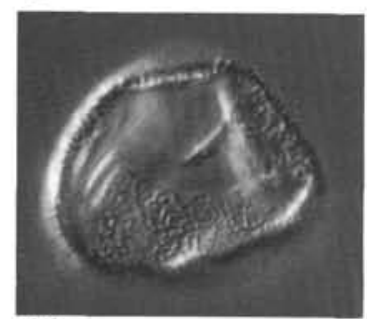

14

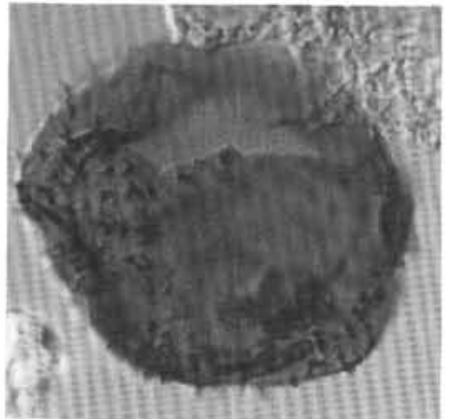

2

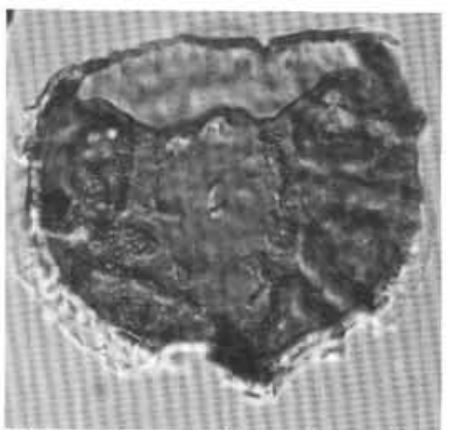

6

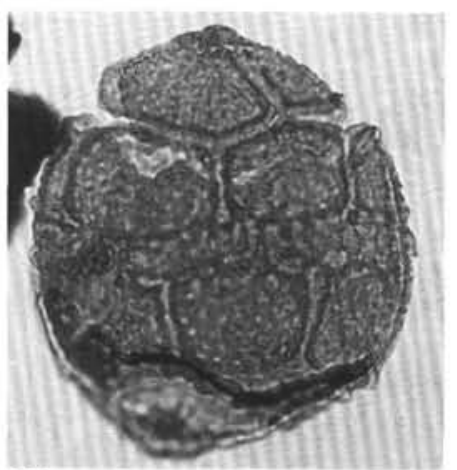

10

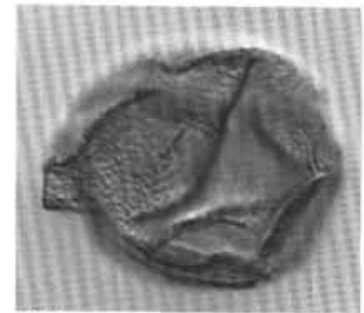

15

16

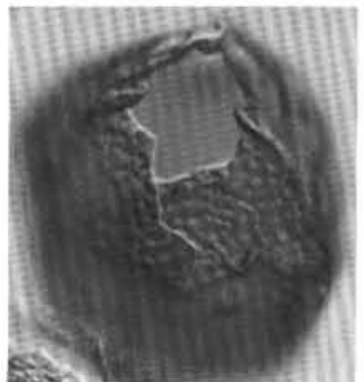

3

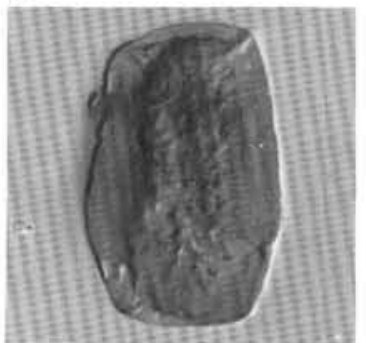

7
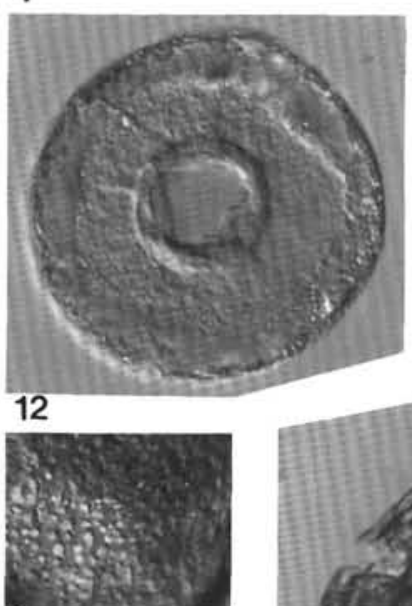

11

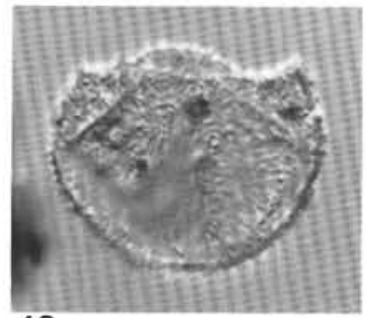

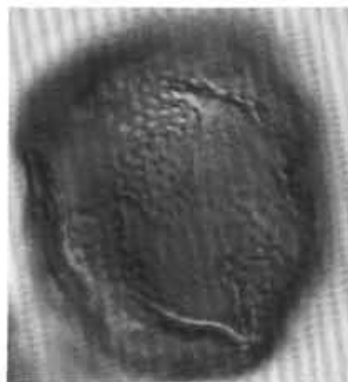

4

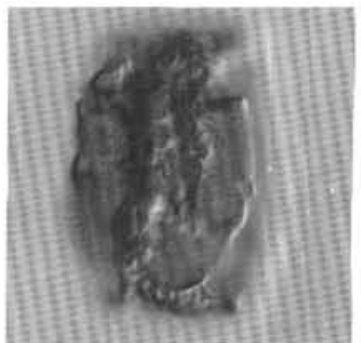

8

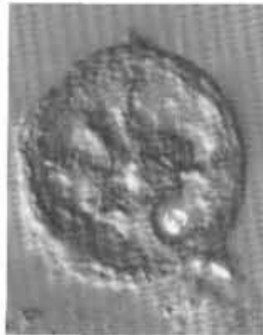

13

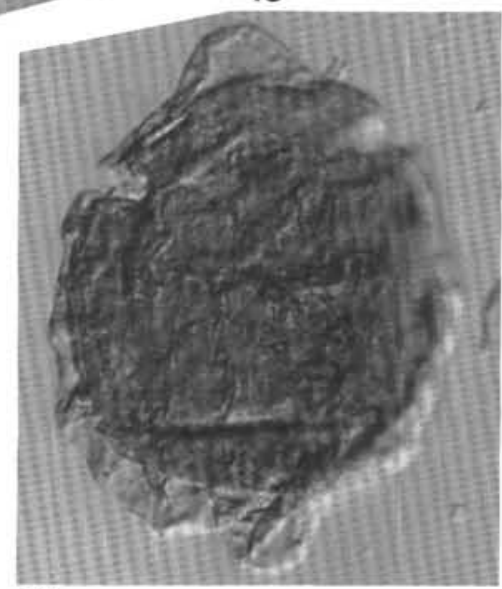

17

Plate 6. (1-9, 11-17, IC; 10, BF) 1, 5. Chytroeisphaeridia sp. 1. Sample 105-647A-61R, CC (4)Q31/2; width, $58 \mu \mathrm{m}$ (1, dv.?, ds.?; 2, dv.?, ds.?, lrf.). 2. Batiacasphaera sp. C (note spines/coni). Sample 105-647A-33R-1, 91-94 cm (1)035/0; max. dia. (excl. ornament), $51 \mu \mathrm{m}$ (subap. v., subap. s.). 3, 4. Batiacasphaera sp. B. Sample $105-647 \mathrm{~A}-35 \mathrm{R}$, CC (1)M40/4; max dia., $57 \mu \mathrm{m}$ (3, ap. v., ap. s.; 4, ap. v., antap. s.). 6. Alisocysta sp. cf. A. ornata. Sample 105-647A-63R, CC (1)T19/0; max. dia., $55 \mu \mathrm{m}$ (vv., vs.). 7, 8. Acritarch sp. 1. Sample 105-647A-17R, CC (4)R32/2; length, $32 \mu \mathrm{m}$ (7, us.; 8, mf.). 9,11. Batiacasphaera sp. A. Sample 105-647A-59R, CC (1)P49/0; max. dia., $89 \mu \mathrm{m}$ (9, antap. v., ap. s; 11, antap. v., antap. s.-same mag. as Fig. 9) 10. Alisocysta sp. 1. Sample 105-647A-65R-1, 117-121 cm (1)E17/2; length, $63 \mu$ m (vv., vs.). 12. Acritarch sp. 2. Sample 105-647A-15R, CC (4)M27/3; dia., $40 \mu \mathrm{m}$ (us.) 13. cf. Acritarch sp. 1 Head et al., c, this volume (note cancellous equatorial collar). Sample 105-647A-28R-4, 88-91 cm (1)V51/2; dia., $26 \mu \mathrm{m}$ (mf.). 14, 15. Batiacasphaera micropapillata sensu lato. 14, Sample 105-647A-50R, CC (1)N21/0; max. dia., $30 \mu$ m (antap. v., ap. s.). 15, Sample 105-647A-49R, CC (1) U32/0; max. dia., $39 \mu$ m (note short coni/granules) (subantap. v., subap. s.) 16. Batiacasphaera sp. cf. B. hirsuta. Sample 105-647A-53R-4, 121-125 cm (1)033/0; max. dia., $31 \mu \mathrm{m}$ (hairs, $1.5 \mu \mathrm{m} \mathrm{long}$ ) (lat. v., mf.). 17. Membranophoridium sp. Sample 105-647A-65R-1, 117-121 cm (2)D34/4; length, $62 \mu \mathrm{m}$ (lat. v., us.). 


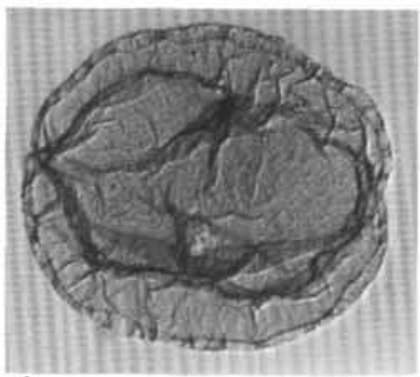

1

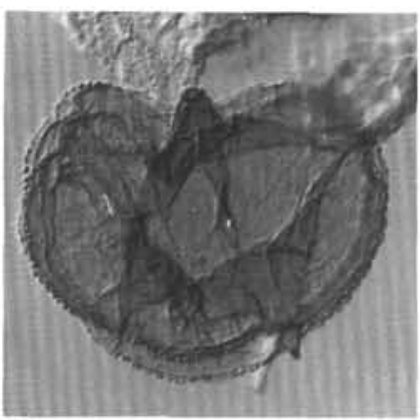

5

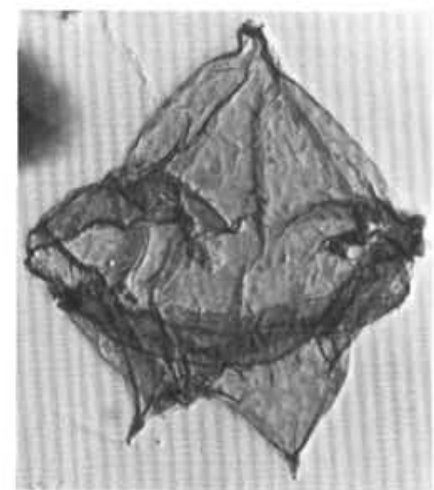

9

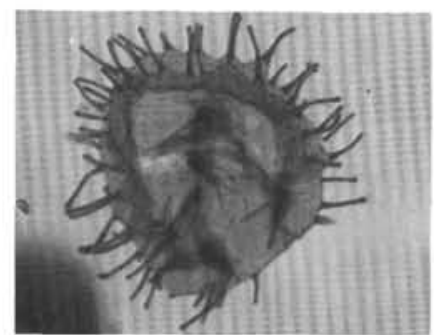

13

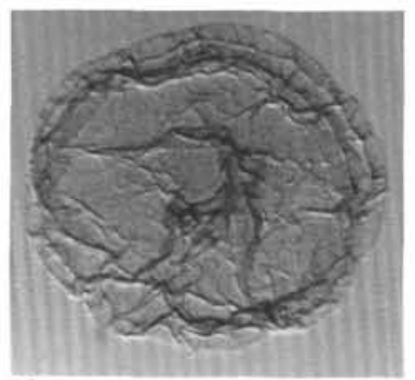

2

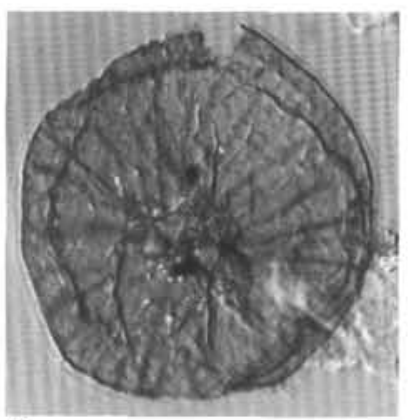

6

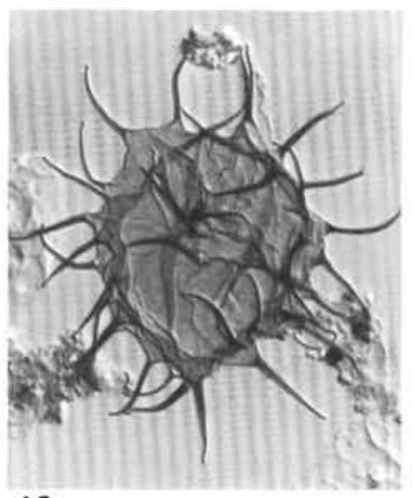

10

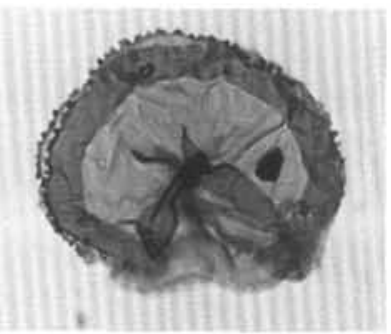

14

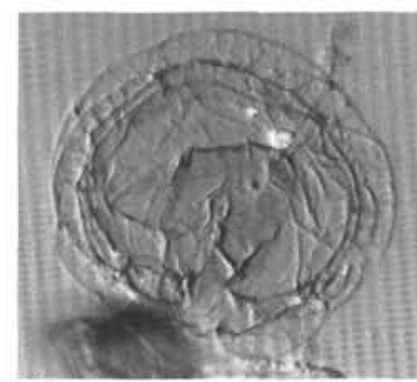

3
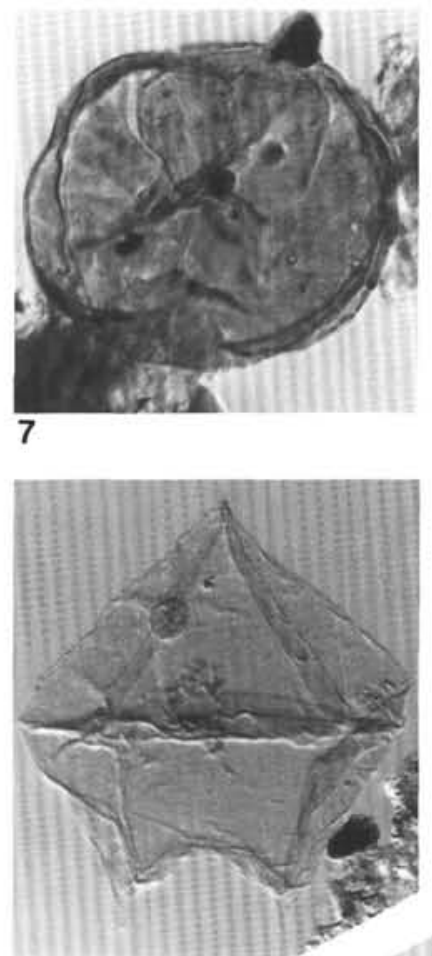

11

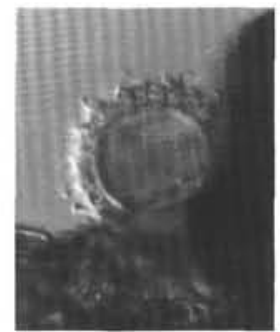

15

16

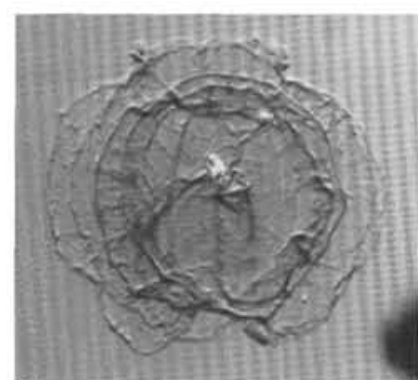

4

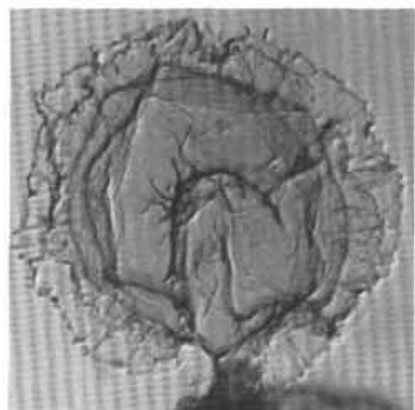

8

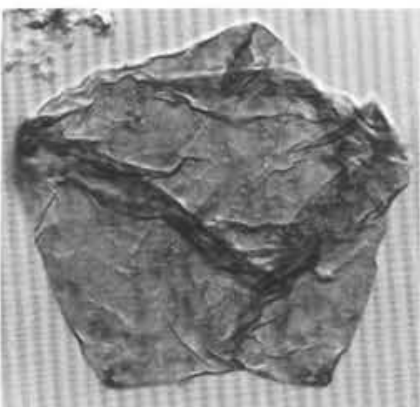

12

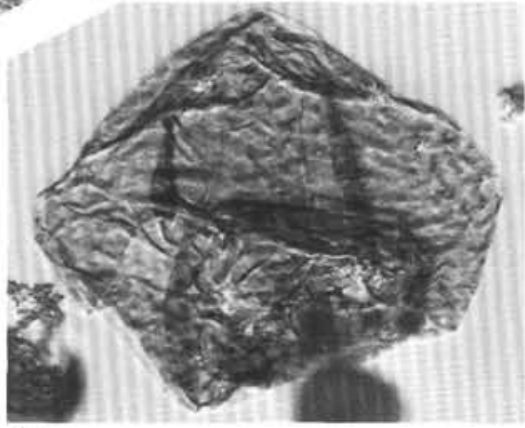

Plate 7. (1-12, IC; 13,14 BF) 1, 2. Selenopemphix sp. 1. 1, Sample 105-647A-30R-3, 100-104 cm (1)P50/0; max. dia., $48 \mu \mathrm{m}$ (antap. v.?, mf.). 2 , Sample 105-647A-28R-4, 88-91 cm (4)K33/0; max. dia., $49 \mu \mathrm{m}$ (ap. v.?, mf.). 3. Selenopemphix? sp. 2. Sample 105-647A-21R, CC (1)R37/2; max. dia., $48 \mu \mathrm{m}$ (polar v., mf.). 4, 8. Selenopemphix? sp. 3. 4, Sample 105-647A-22R, CC (4)G15/0; max. dia., $48 \mu \mathrm{m}$ (polar v., mf.). 8, Sample 105-647A-24R-2, 142-145 cm (1)F14/1; max. dia., $54 \mu \mathrm{m}$ (polar v., mf.). 5, 9. Phelodinium sp. 3. 5, Sample 105-647A-30R-3, 100-104 cm (1)M41/3; max. dia., $55 \mu$ m (ap. v., mf.). 9, Sample 105-647A-30R-3, 100-104 cm (1)M31/0; length, $69 \mu \mathrm{m}$ (dv.?, mf.). 6. Phelodinium sp. 4. 6, Sample 105-647A-30R-3, 100-104 cm (1)M35/3; max. dia., $54 \mu$ m (polar v., mf.). 7. Phelodinium sp. 4?. Sample 105-647A-33R-1, 91-94 cm (1)S9/4; max. dia., $61 \mu \mathrm{m}$ (ap. v.?, mf.). 10. Selenopemphix armata. Sample 105-647A-30R-3, 100-104 cm (1)M27/1; max. dia. (excl. proc.), $38 \mu \mathrm{m}$ (polar v., mf.). 11. Phelodinium sp. 1. Sample 105-647A-21R, CC (1)F49/0; length, $79 \mu \mathrm{m}$ (dv.?, ds.?). 12. Phelodinium sp. 2?. Sample 105-647A-21R, CC (1)F34/4; length, $69 \mu \mathrm{m}$ (dv.?, mf.) 13. Selenopemphix sp. 4. Sample 105-647A-30R-3, 100-104 cm (1)G34/3; max. dia. (excl. proc.), $30 \mu \mathrm{m}$ (polar v., mf.). 14. Selenopemphix sp. 5. Sample 105-647A-36R, CC (1)T36/3; max. dia., $35 \mu \mathrm{m}$ (antap. v., mf.). 15. Cordosphaeridium callosum. Sample 105-647A-59R, CC (1)R33/3; max. dia. (excl. proc.), $17 \mu$ m (lat. v., mf.). 16. Phelodinium sp. 2. Sample 105-647A-21R, CC (1)T40/1; max. dia., $87 \mu \mathrm{m}$ (dv.?, mf.). 


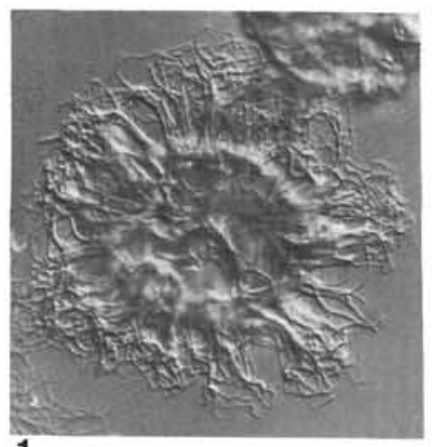

1

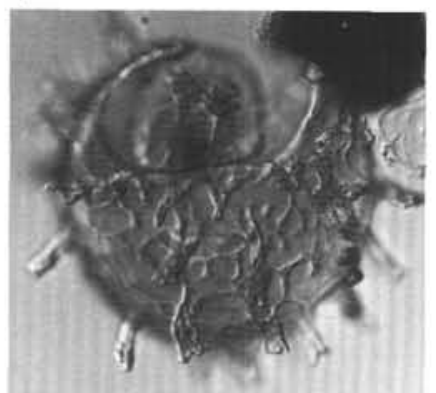

5

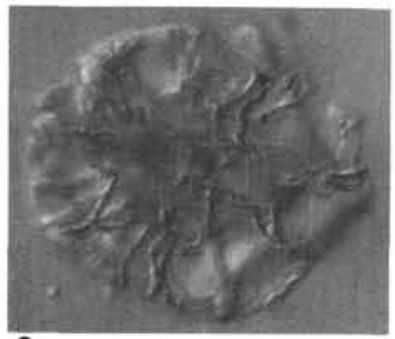

9

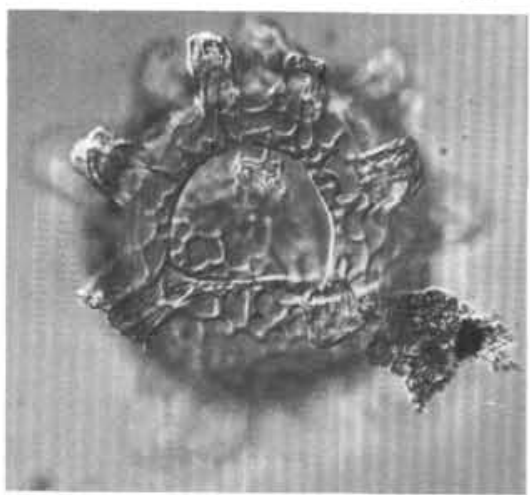

13

10

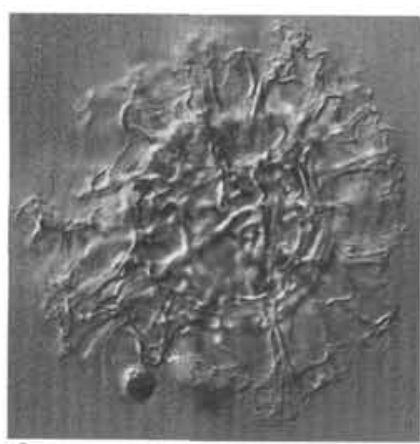

2

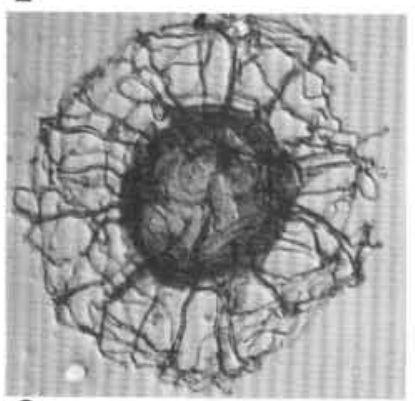

6
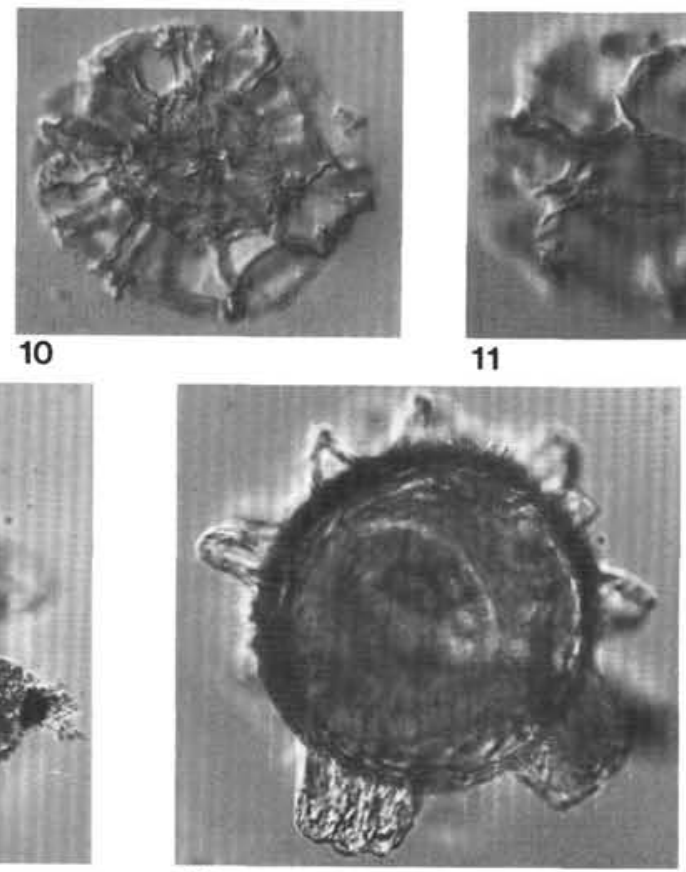

14

3

7

11
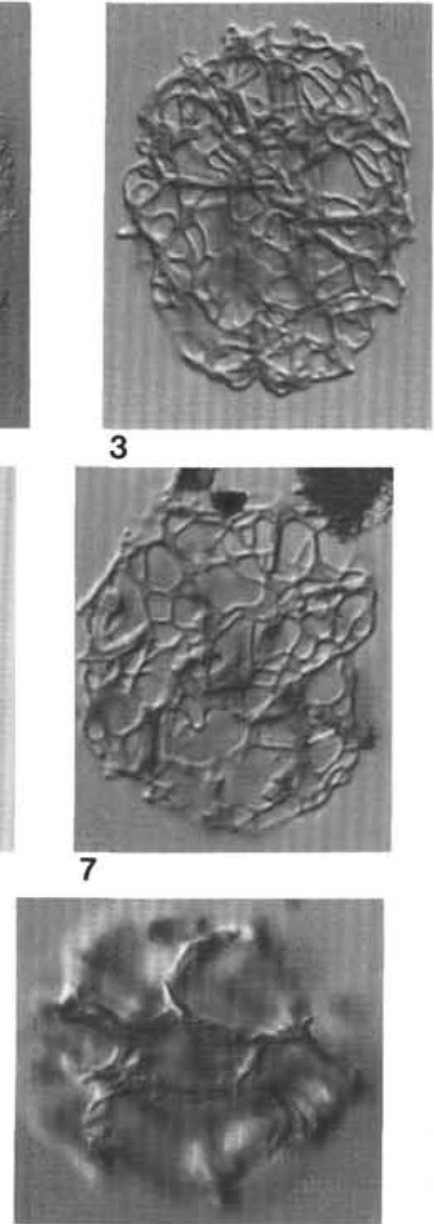

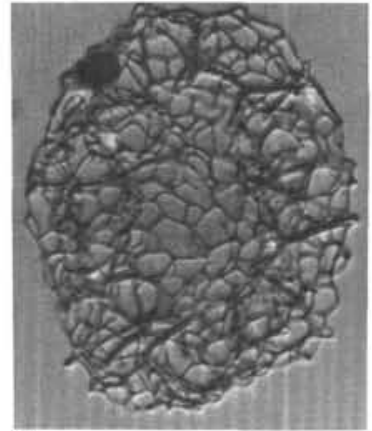

4

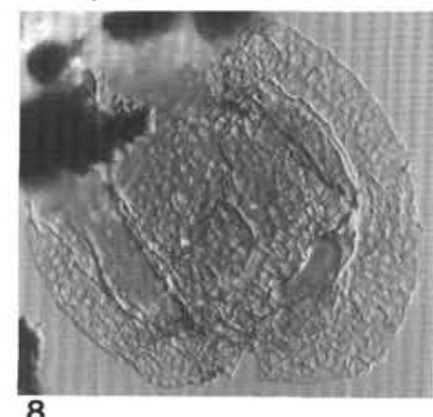

8

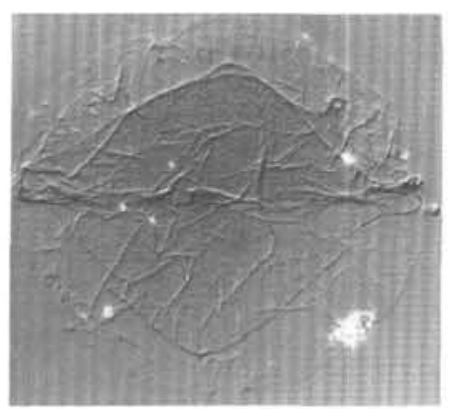

12

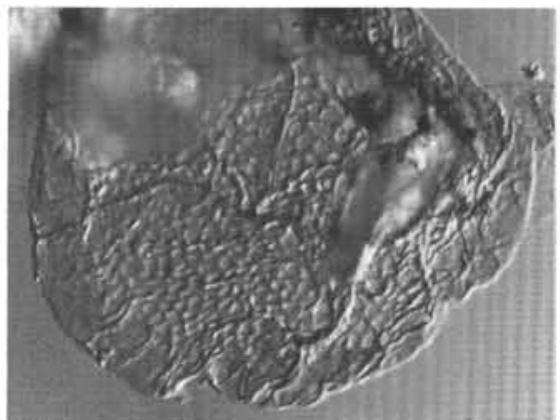

15

Plate 8. (all figs. IC) 1, 2. Impletosphaeridium luxurium. 1, Sample 105-647A-49R, CC (1)Q39/1; max. dia. (excl. proc.), $31 \mu \mathrm{m}$ (uncert. v., us.). 2, Sample 105-647A-49R, CC (1)U32/2; max. dia. (excl. proc.), $33 \mu$ m (uncert. v., us.). 3, 4, 7. Nematosphaeropsis? sp. 2. 3, Sample 105-647A19R, CC (5)09/2; max. dia., $57 \mu \mathrm{m}$ (uncert. v., us.). 4, Sample 105-647A-21R, CC (1)D42/2; max. dia., $66 \mu \mathrm{m}$ (uncert. v., us.). 7, Sample 105-647A19R, CC (5)G34/3; max. dia., $46 \mu \mathrm{m}$ (subantap. v., subantap. s.). 5. Cordosphaeridium funiculatum sensu Williams and Bujak, 1977b. Sample 105-647A-32R, CC (1)J36/3; max. dia. (excl. proc.), $77 \mu \mathrm{m}$ (dv., ds.). 6. Nematosphaeropsis? sp. 1. Sample 105-647A-68R-2, 97-99 cm (1)019/3; periphragm max. dia., $57 \mu \mathrm{m}$ (uncert. v., us.) (= Cannosphaeropsis sp. A of Costa and Downie, 1979b?) 8. Heteraulacacysta porosa. Sample 105-647A-33R-1, 91-94 cm (1)N32/0; max. dia., $102 \mu \mathrm{m}$ (antap. v.?, antap. s.?). 9, 10, 11. Impagidinium? sp. D. Sample 105-647A-63R-1, 105-108 cm (2)Q44/4; max. dia. periphragm, $47 \mu$ m (lat. v., 9, us.; 10, mf.; 11, 1s.). 12. Phelodinium? sp. 5. Sample 105-647A-17R, CC (4)K39/0; max. dia., $94 \mu \mathrm{m}$ (uncert. v., us.). 13, 14. Cordosphaeridium sp. cf. C. funiculatum. Sample 105-647A-33R, CC (2)T19/3; central body dia., 74 $\mu \mathrm{m},(13$, dv., ds.; 14, dv., mf.). 15. Heteraulacacysta sp. A. Sample 105-647A-53R-4, 121-125 cm (1)L54/0; max. dia., $77 \mu$ m (antap. v., antap. s.). 


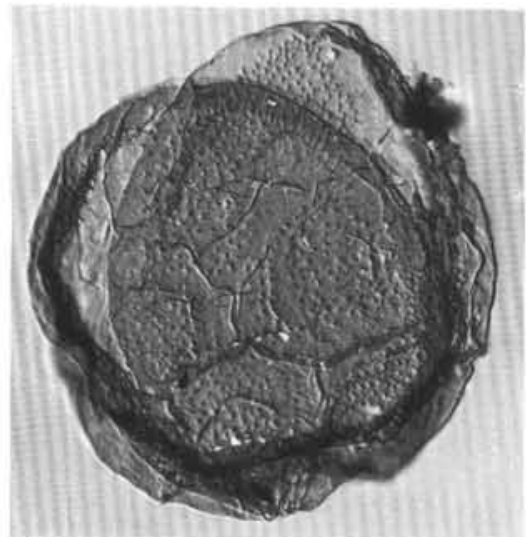

1

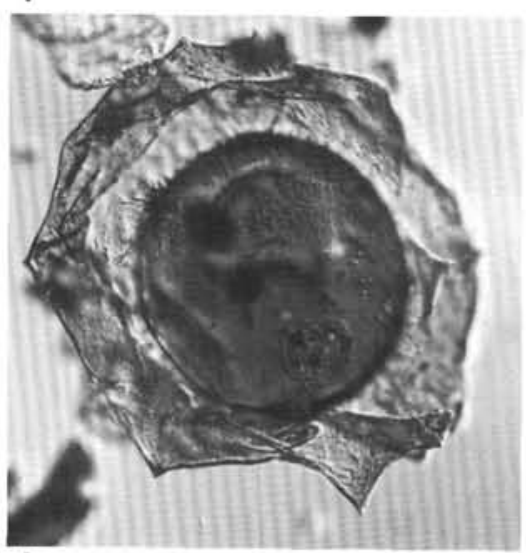

4

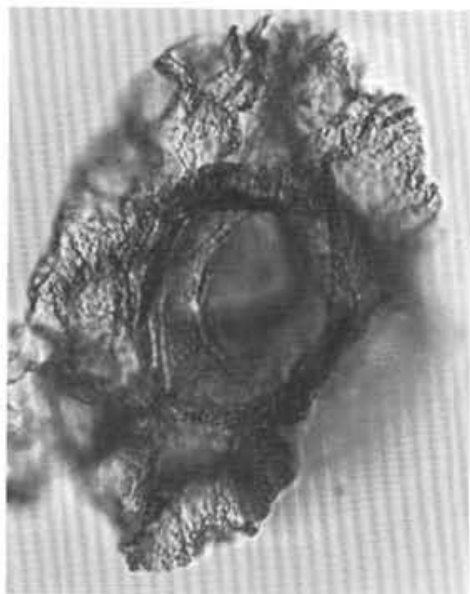

7
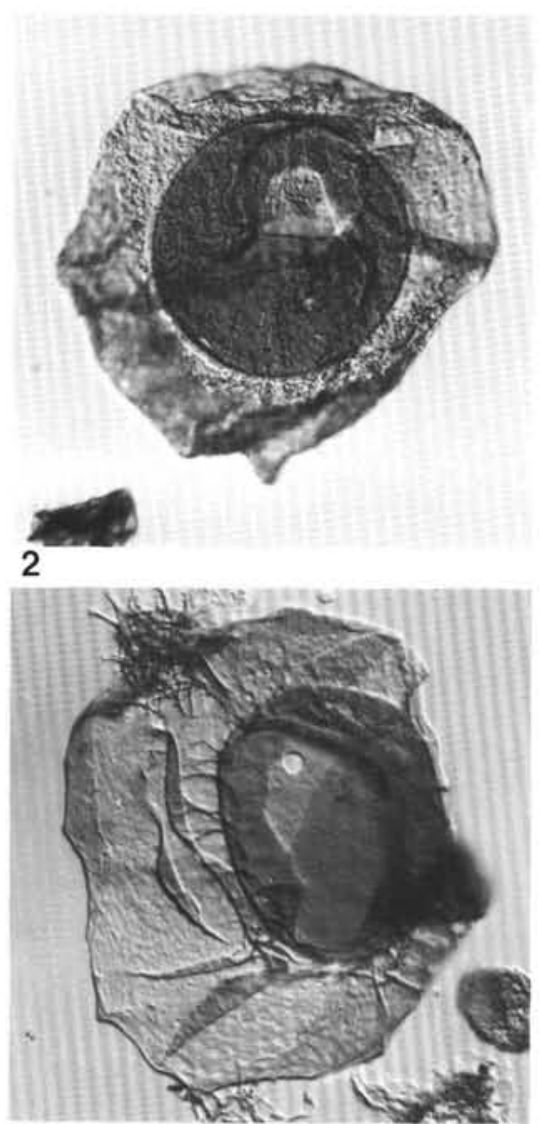

5

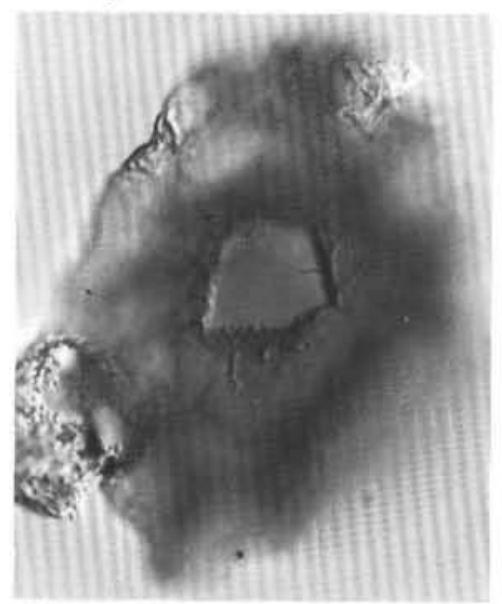

8

9

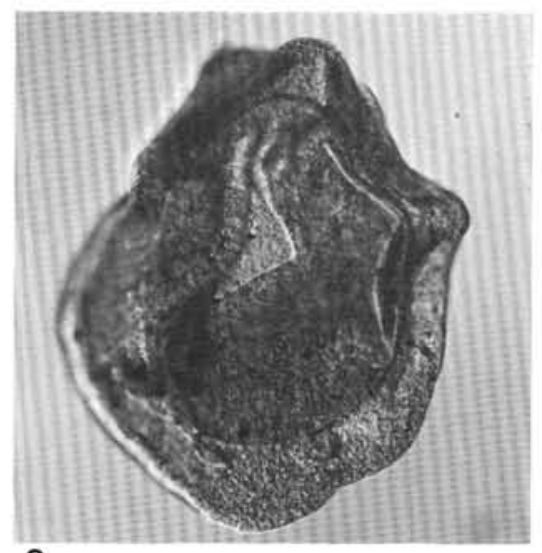

3

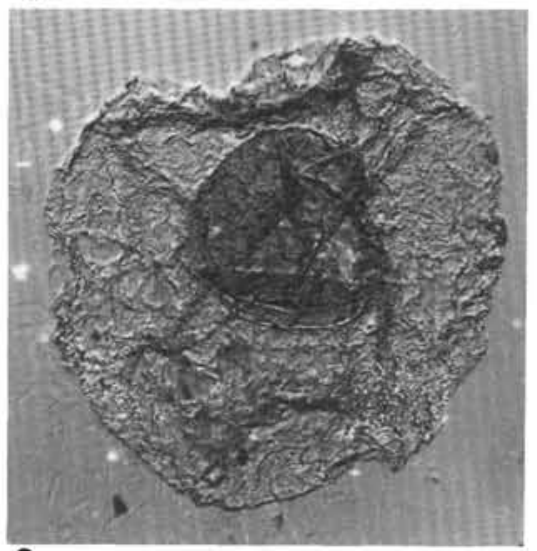

6

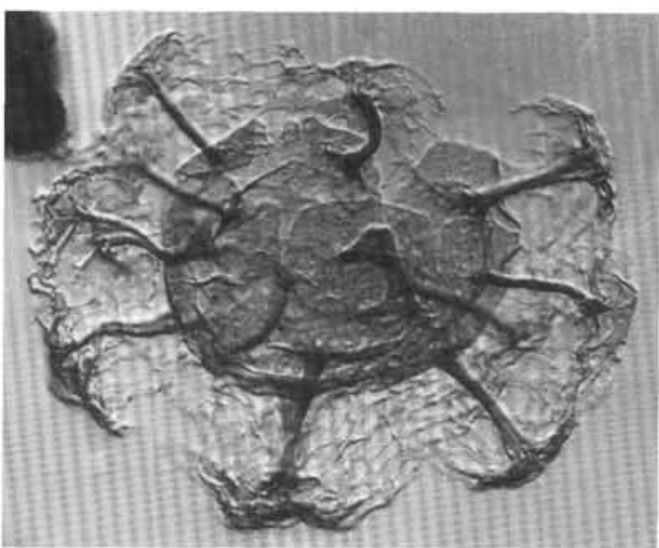

Plate 9. (all figs. IC) 1. Heteraulacacysta sp. A of Costa and Downie, 1979b. Sample 105-647A-66R-1, 66-69 cm (K3)R39/3; max. dia., 89 $\mu \mathrm{m}$ (antap. v.?, antap. s?). 2, 3. Thalassiphora pelagica. Sample 105-647A-68R-1, 129-132 cm (Kl)J41/1; max. dia., $154 \mu \mathrm{m}$ (dv., ds.). 3, Sample 105-647A-69R, CC (2)J21/1; max. dia., $131 \mu \mathrm{m}$ (dv., ds.). 4. Thalassiphora sp. C. Sample 105-647A-21R, CC (4)S19/1; max. dia., 166 $\mu \mathrm{m}$ (dv., vs.). 5. Thalassiphora sp. D. Sample $105-647 \mathrm{~A}-17 \mathrm{R}, \mathrm{CC}(2) \mathrm{M} 33 / 0$; max. dia., $139 \mu \mathrm{m}$ (lat. v., mf.). 6. Thalassiphora sp. A. Sample 105-647A64R-3, 88-91 cm (1)B29/4; max. dia., $117 \mu \mathrm{m}$ (vv., mf.). 7, 8. Thalassiphora sp. B. Note simple processes surrounding archeopyle. Sample 105647A-35R, CC (1)J38/1; max. dia., $101 \mu \mathrm{m}$ (7, dv., ds.; 8, dv., ds.). 9. Eatonicysta ursulae. Sample 105-647A-66R-1, 15-18 cm (1)U33/4; max. dia., periphragm, $99 \mu \mathrm{m}$ (dv., mf.). 


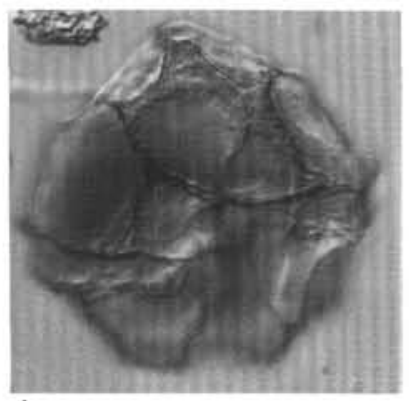

1

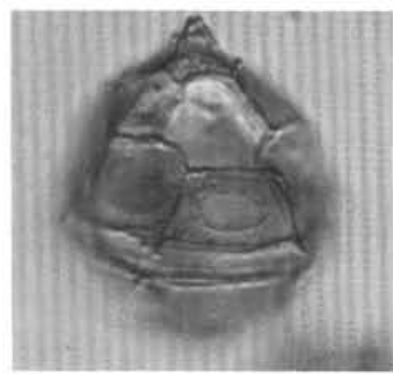

5

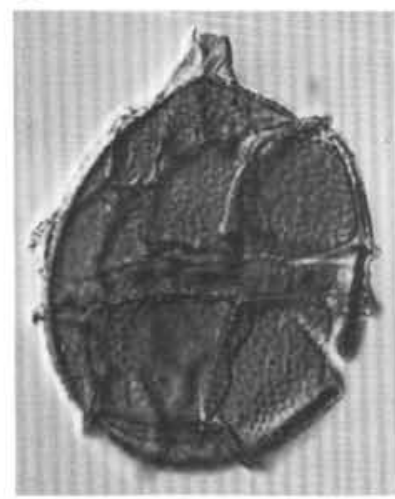

9

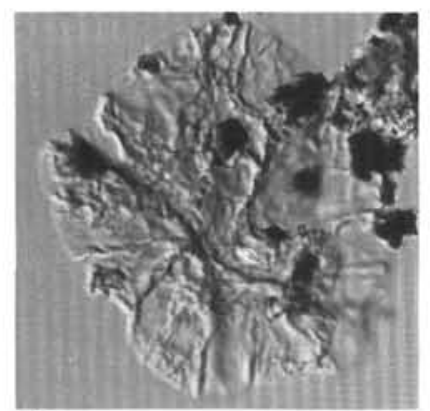

13

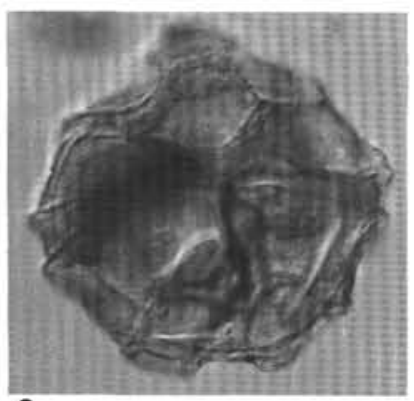

2

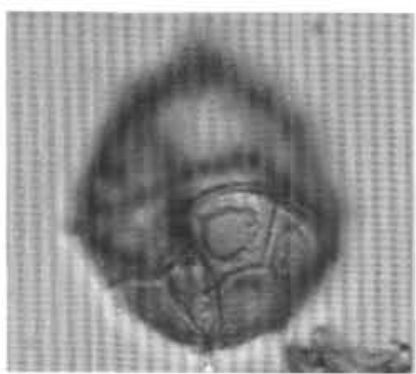

6

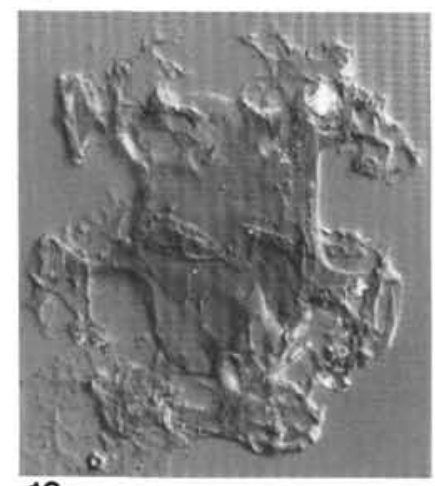

10

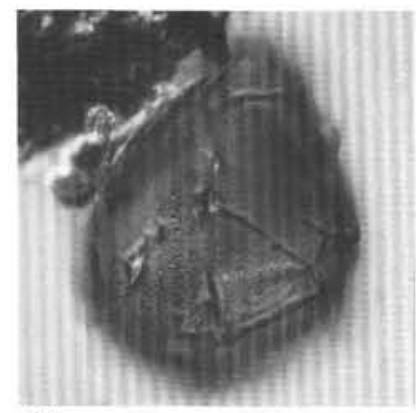

14

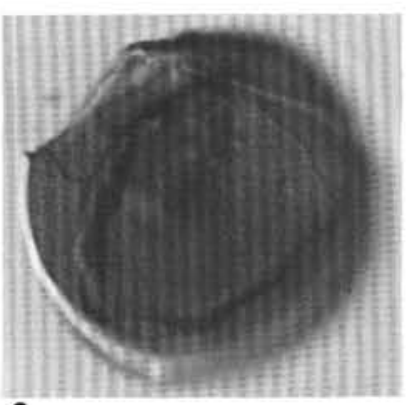

3

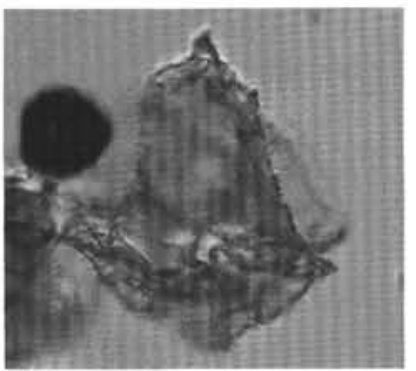

7

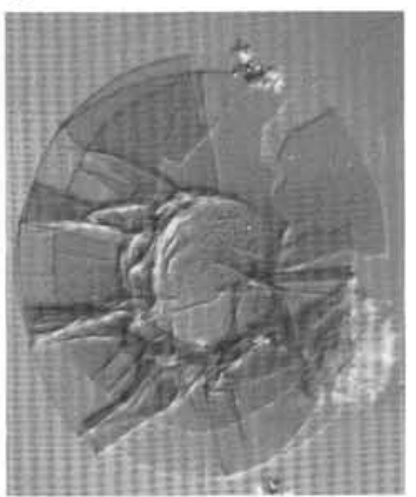

11

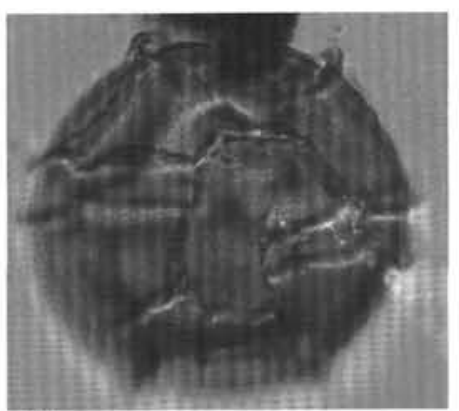

15

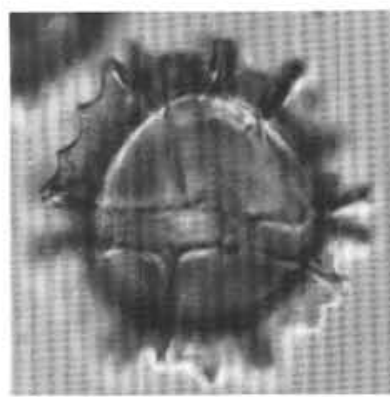

4

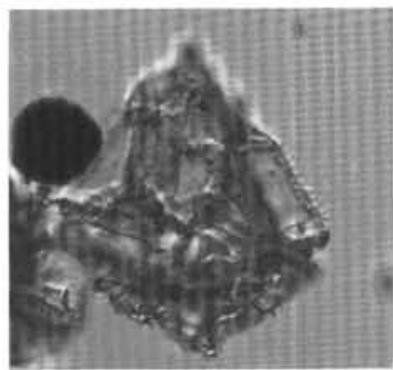

8

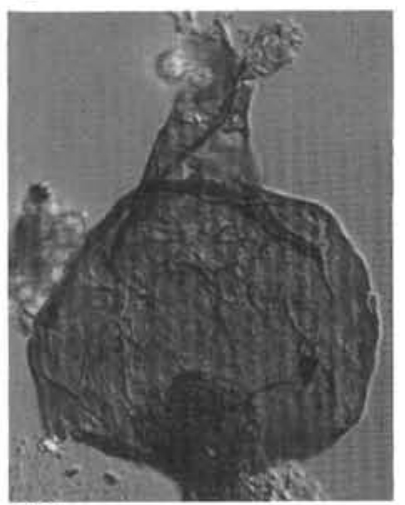

12

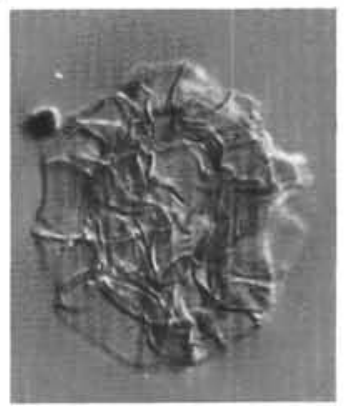

16

Plate 10 (all figs. IC) 1,2. Phthanoperidinium? brooksii. Sample 105-647A-59R, CC (1)N34/2; length, $45 \mu \mathrm{m}(1,2$ vv.: 1, vs.; 2, ds.). 3. Acritarch sp. 3. Note fine, regular reticulation. Sample 105-647A-30R-3, 100-104 cm (1)T28/1; max. dia., $47 \mu \mathrm{m}$ (lat. v., us.). 4. Impagidinium sp. B. Sample 105-647A-24R-2, 142-145 cm (6)J33/1; max. dia. (incl. crests), $44 \mu \mathrm{m}$ (vv., ds.). 5, 6. Phthanoperidinium sp. A. Sample 105-647A-24R-2, $142-145 \mathrm{~cm}$ (6)J33/1; length, $40 \mu \mathrm{m}$. (dv.: 5, ds.; 6, vs.). 7, 8. Phthanoperidinium sp. cf. P. echinatum. Sample 105-647A-51R, CC (1)K45/0; length, $39 \mu \mathrm{m}(7,8$, rt. lat. v.: 7, rt. lat. s.; 8, mf.). 9. Gonyaulacysta sp. 1. Sample 105-647A-65R-1, 117-121 cm (2)U19/2; length, $65 \mu \mathrm{m}$ (vv., ds.). 10. Distatodinium scariosum. Sample $105-647 \mathrm{~A}-32 \mathrm{R}, \mathrm{CC}(1) \mathrm{Q} 18 / 3$; central body length, $39 \mu \mathrm{m}$ (lat. v., us.). 11. Impagidinium velorum. Sample 105-647A-17R, CC (2)F30/0; max. dia. (incl. crests), $66 \mu \mathrm{m}$ (uncert. v., mf.). 12. Rhizophagites sp. of Wrenn and Kokinos, 1986. Sample 105-647A-33R-1, 91-94 cm (1)F34/1; length, $73 \mu \mathrm{m}$ (uncert. v., us.). 13. Impagidinium? pallidum. Sample 105-647A-52R-4, 25-28 cm (2)R43/3; max. dia., $49 \mu \mathrm{m}$ (uncert. v., us.). 14. Impagidinium sp. C. Sample 105-647A-33R-1, 91-94 cm (1)T11/2; max. dia. (incl. crests), $47 \mu \mathrm{m}$ (subvv., subvs.). 15. Impagidinium dispertitum. Sample 105-647A-65R-1, 117-121 cm (1)M46/1; max. dia. (excl. crests), $67 \mu \mathrm{m}$ (dv., vs.). 16. Impagidinium sp. A. Sample 105-647A-64R-3, 88-91 cm (2)N31/1; max. dia. (incl. crests), $39 \mu \mathrm{m}$ (uncert. v., mf.). 


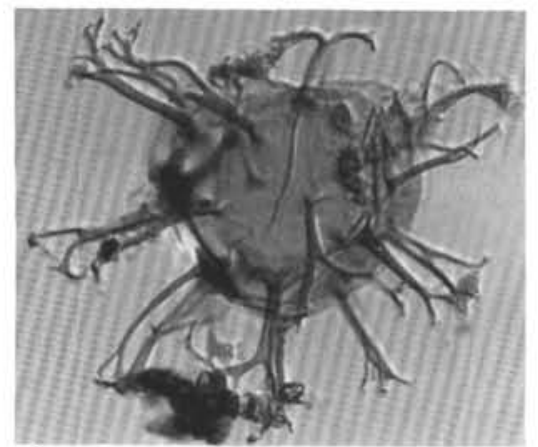

1

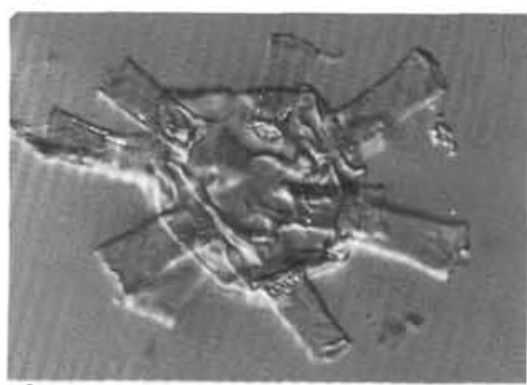

4

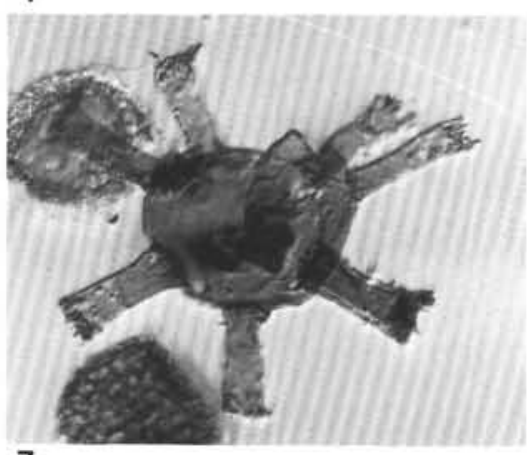

7

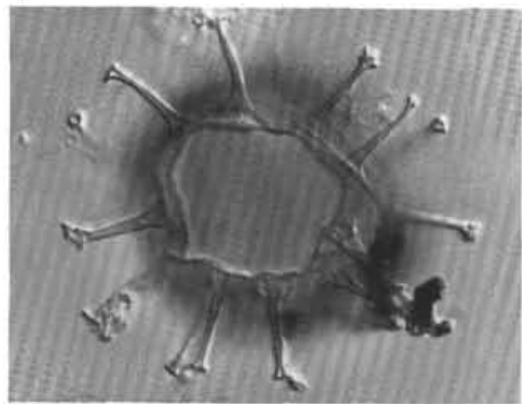

10

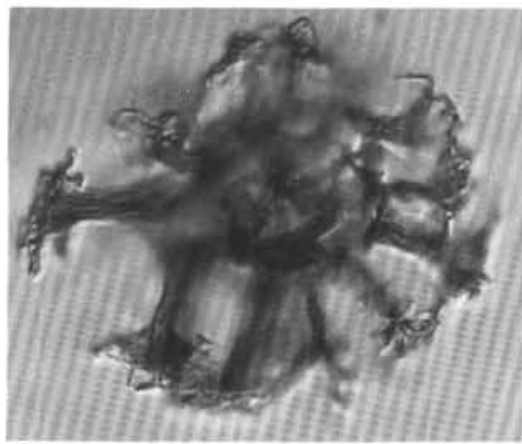

2

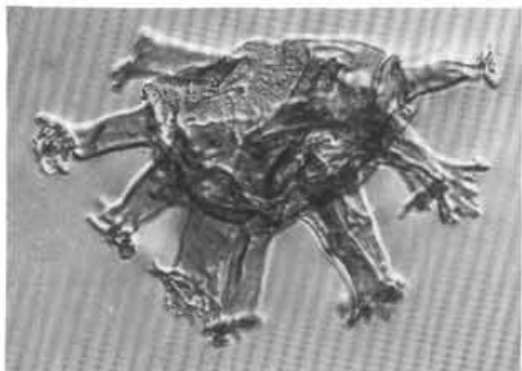

5
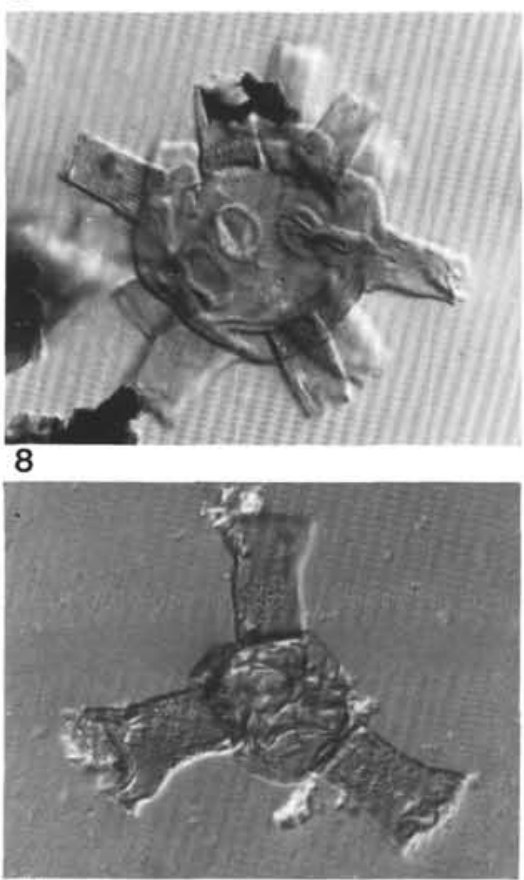

11

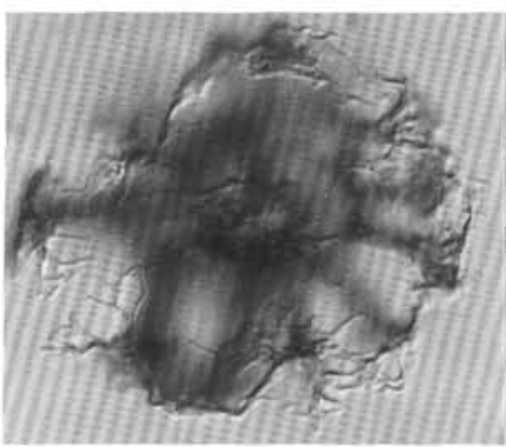

3

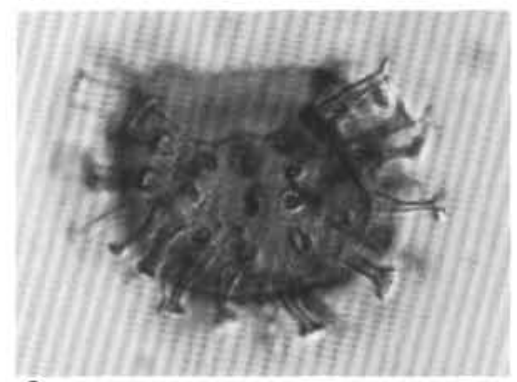

6

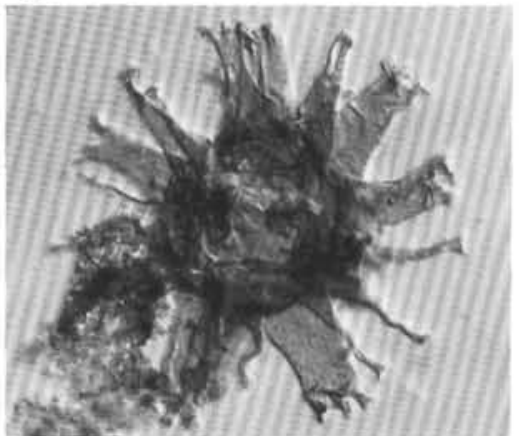

9

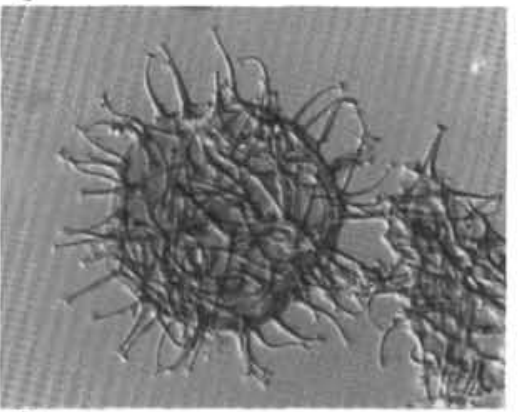

12

Plate 11. (all figs. IC) 1. Surculosphaeridium? sp. A. Sample 105-647A-15R, CC (4)R30/2; central body dia., $39 \mu \mathrm{m}$ (lat. v., us.). 2, 3. Cordosphaeridium minimum sensu Eaton, 1976?. Sample 105-647A-30R-3, 100-104 cm (1)N24/2; max., dia. (incl. proc.), $59 \mu \mathrm{m}$ (uncert. v.: 2, us.; 3, us., hrf.) 4, 8. Litosphaeridium sp. A. 4, Sample 105-647A-64R, CC (1)L17/0; central body dia., $34 \mu \mathrm{m}$ (lat. v., us.). 8, Sample 105-647A-65R-1, 117-121 cm (1)F17/2; central body, $34 \mu \mathrm{m}$ (lat. v., us.). 5. Homotryblium sp. A. Sample 105-647A-68R-2, 76-79 cm (K1)L9/1; central body dia., $44 \mu \mathrm{m}$ (lat. v., mf.). 6. Dapsilidinium sp. A. Sample 105-647A-52R-4, 25-28 cm (2)Q47/3; central body, dia., $42 \mu \mathrm{m}$ (vv., vs.). 7. Dinocyst sp. D. Sample 105-647A-67R-2, 28-31 cm (2)J42/3; central body, $33 \mu$ m (lat. v., us.). 9. Hystrichokolpoma unispinum. Sample 105-647A-67R-2, 28-31 cm (2)K29/1; length (incl. process), $54 \mu \mathrm{m}$ (ap. v.?; ap. s.?). 10. Dapsilidinium pseudocolligerum. Sample 105-647A-15R, CC (4)R31/1; central body dia., $45 \mu \mathrm{m}$ (ap. v., ap. s.). 11. Litosphaeridium? sp. B. Sample 105-647A-63R, CC (1)U5/1; max. dia. (incl. proc.), $57 \mu \mathrm{m}$ (uncert. v., us.) (operculum? with 4 processes). 12. Polysphaeridium sp. A. Sample 105-647A-17R, CC (2)N19/0; central body dia., $38 \mu \mathrm{m}$ (uncert. v., mf.). 


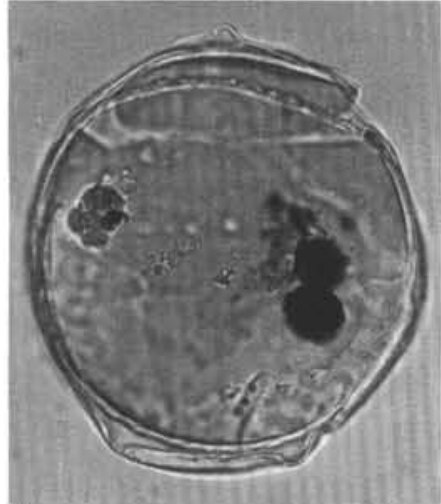

1

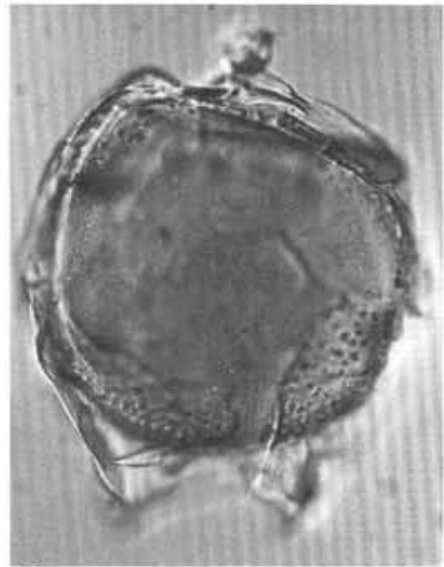

5

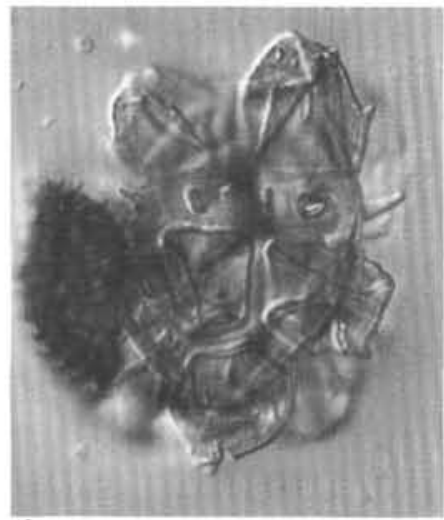

9

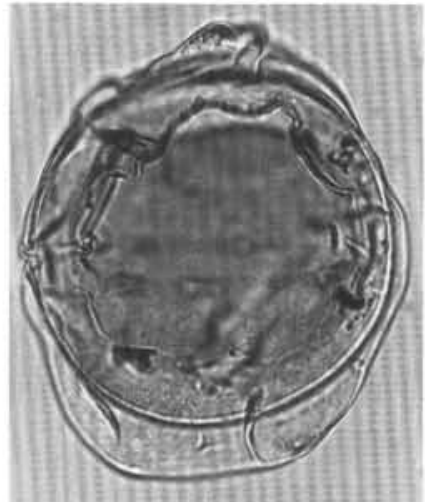

2

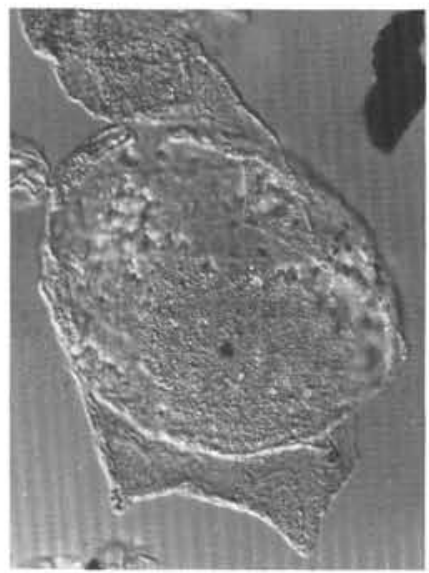

6

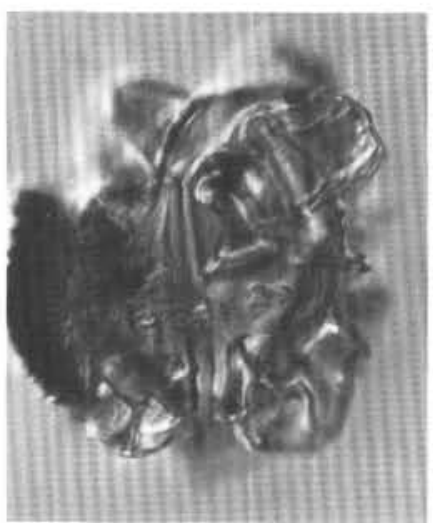

10

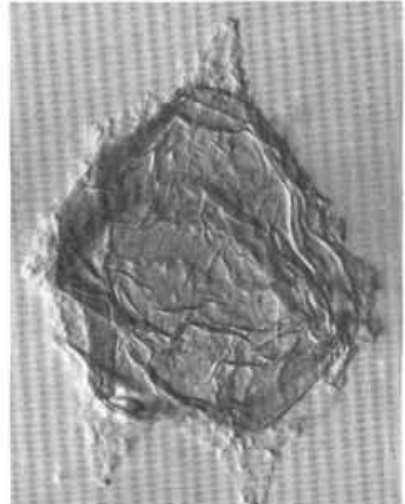

3

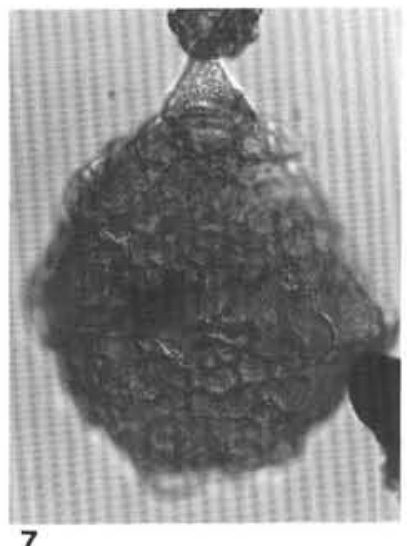

7

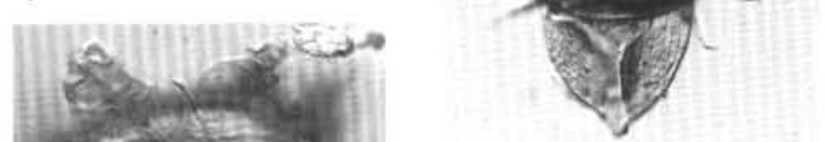

12

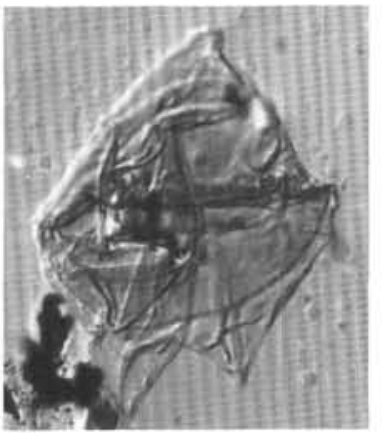

13

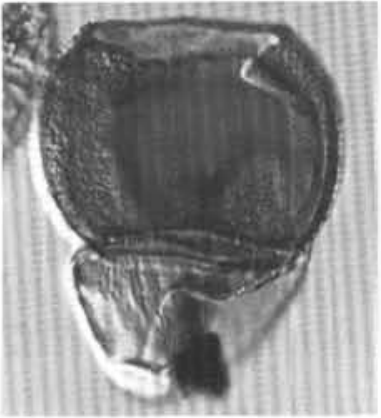

4

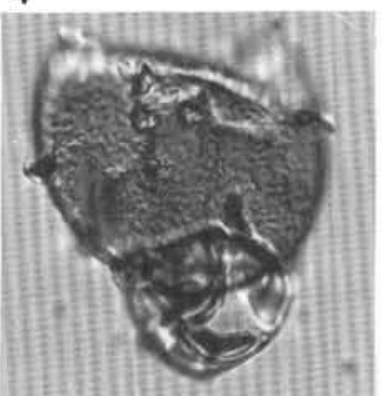

8
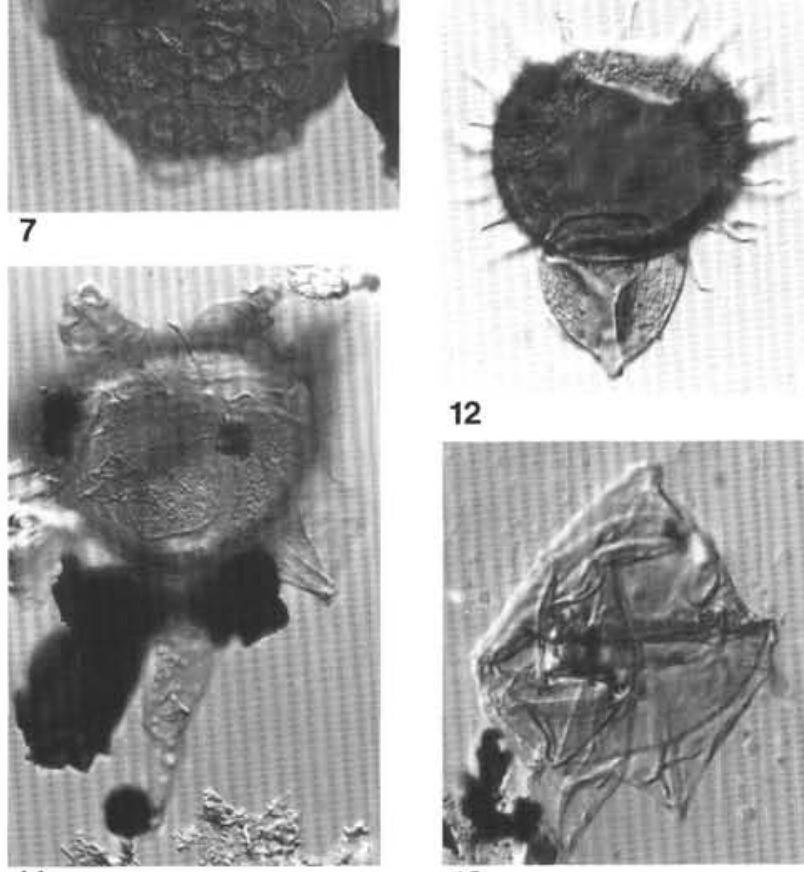

11

Plate 12 (1,2 BF; 3-13 IC) 1, 2. Deflandrea leptodermata. 1, Sample 105-647A-19R, CC (5)L33/O; pericyst length, $100 \mu \mathrm{m}$ (dv., mf.). 2 , Sample 105-647A-61R, CC (4)M36/4; pericyst length, $90 \mu \mathrm{m}$ (vv., mf.). 3. Deflandrea sp. cf. D. sagittula. Sample 105-647A-65R-1, 117-121 cm (1)D35/4; pericyst length, $73 \mu \mathrm{m}$ (uncert. v., mf.). 4. Duosphaeridium sp. cf. D. rugosum. Sample 105-647A-65R-1, 117-121 cm (2)J30/0; overall length, $48 \mu \mathrm{m}$ (vv.?, vs.?). 5. Deflandrea heterophlycta. Sample 105-647A-50R, CC (1)G28/2; pericyst length, $112 \mu \mathrm{m}$ (vv., vs.). 6. Deflandrea oebisfeldensis. Sample 105-647A-35R, CC (1)M47/3; pericyst length, $117 \mu \mathrm{m}$ (vv., vs.; reworked specimen showing finely pitted periphragm). 7. Samlandia chlamydophora. Sample 105-647A-59R, CC (1)J48/2; length, $88 \mu \mathrm{m}$, (left lat. v., left lat. s.). 8. Diphyes sp. A. Sample 105-647A-62R, CC (1)L13/2; overall length, $43 \mu \mathrm{m}$ (lat. v., us.) (note sparsely distributed coni). 9, 10. Hystrichokolpoma globulum Michoux, 1985. Sample 105-647A65R-1, 117-121 cm (1)X10/3; body length, $46 \mu \mathrm{m}$ (9,10, lat. v.: 9, us., 10, ls.). 11. Hystrichokolpoma cinctum. Sample 105-647A-19R, CC (5)J12/2; body length, $64 \mu \mathrm{m}$ (dv., ds.). 12. Diphyes colligerum. Sample 105-647A-66R-2, 29-33 cm (K1)L52/3; overall length, $41 \mu \mathrm{m}$ (vv.?., vs.?). 13. Ceratiopsis? sp. A. Sample 105-647A-65R-1, 117-121 cm (1)S8/4; pericyst length, $54 \mu$ m (uncert. v., us.). 

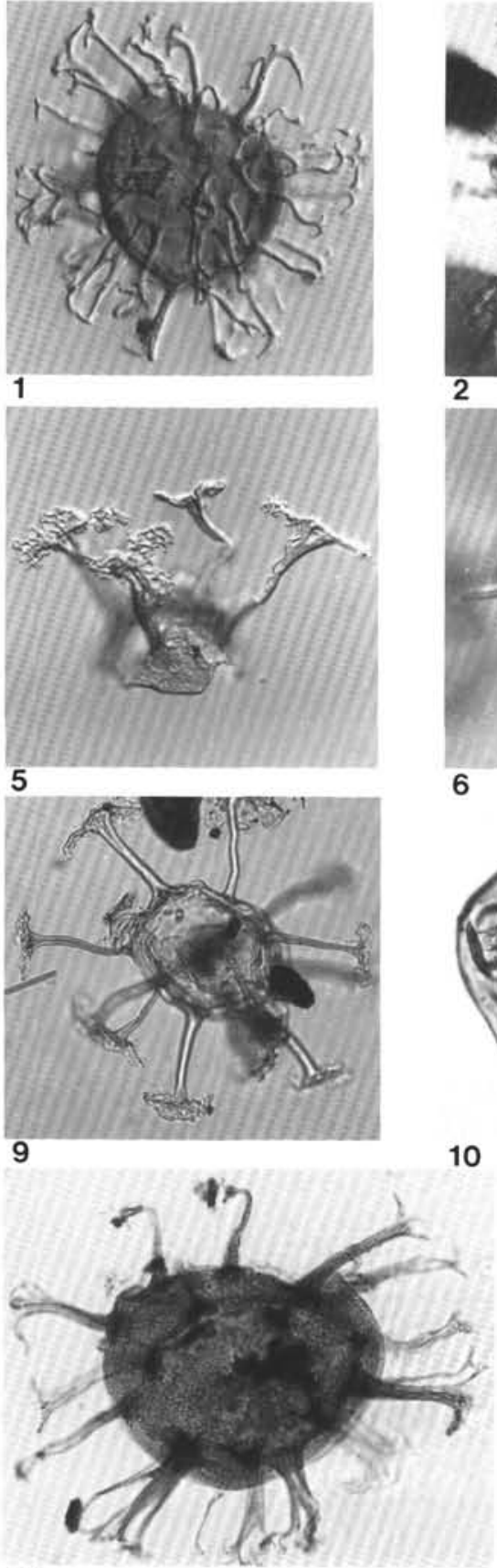

13

6

10
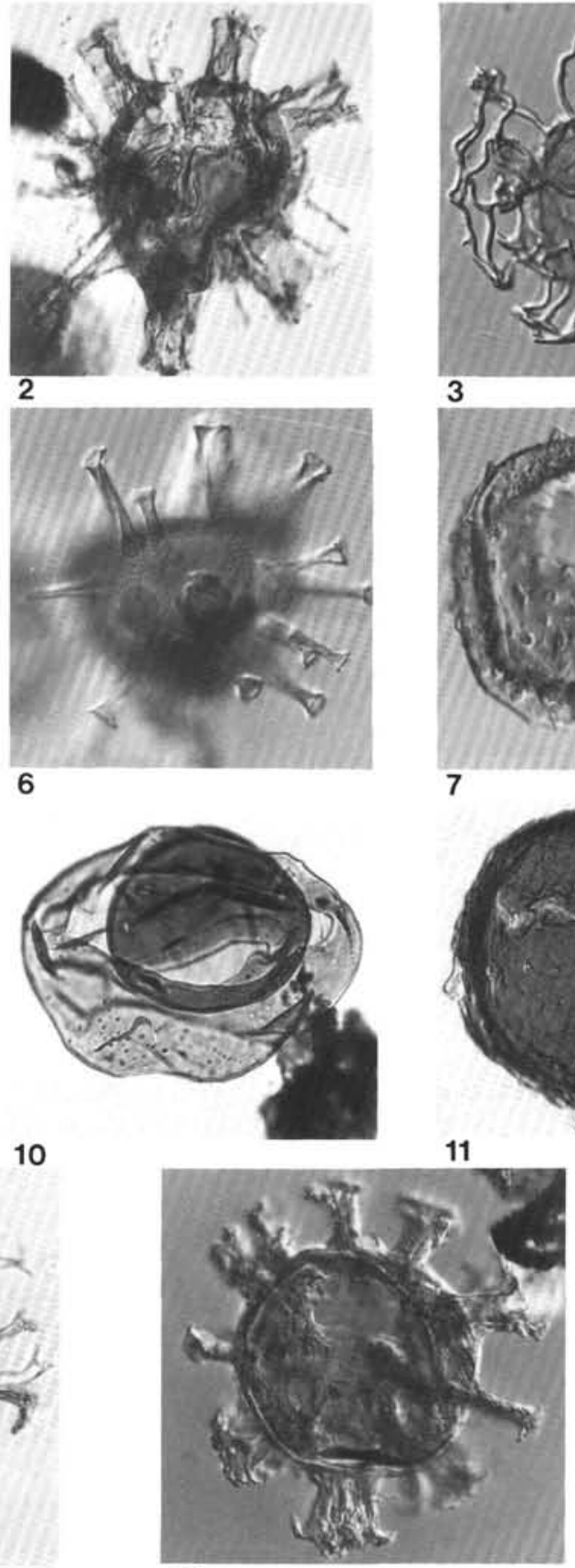

14

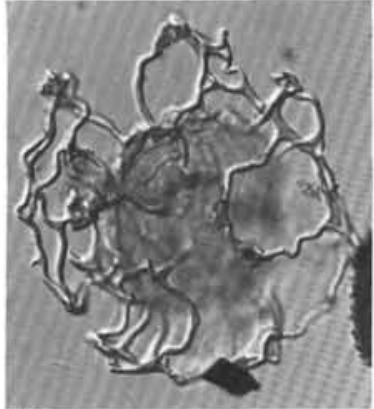

3

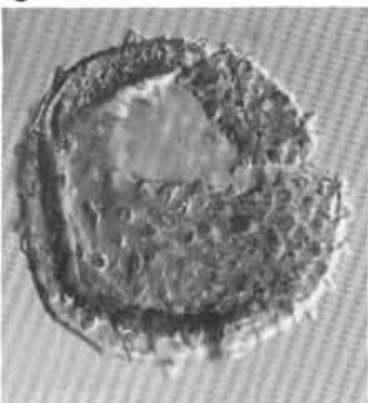

7

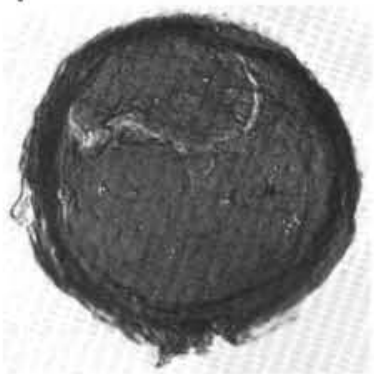

11

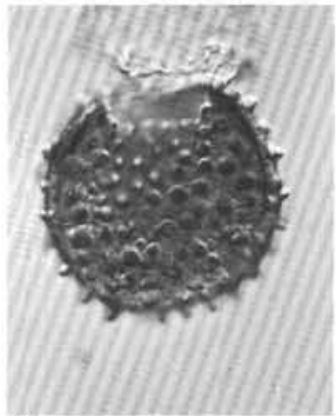

4

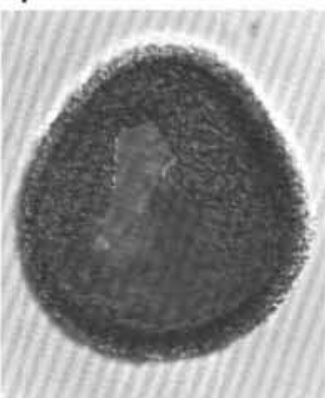

8

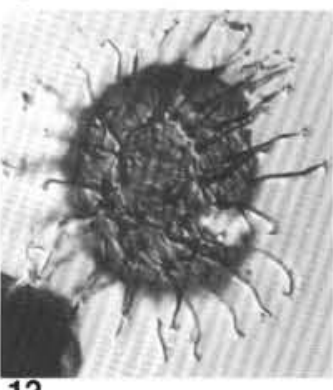

12

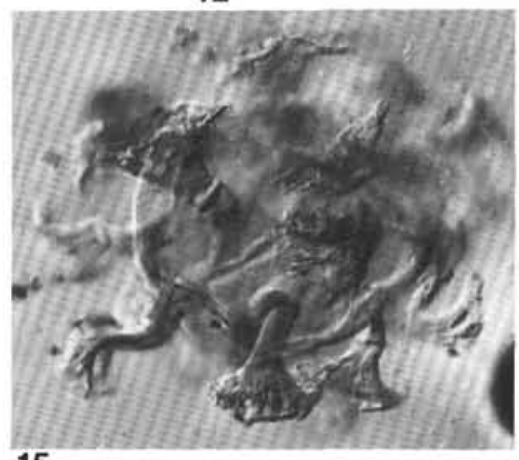

15

Plate 13. (Figs. 1-8, 11,12,14,15, IC; Figs. 9,10,13, BF) 1. Systematophora sp. 1. Sample 105-647A-65R-1, 117-121 cm (2)J30/1; central body, $37 \mu \mathrm{m}$ (dv., ds.). 2. Hystrichokolpoma granulatum. Sample 105-647A-65R-1, 117-121 cm (1)P13/4; $32 \mu \mathrm{m}$ (lat. v., mf.). 3. Adnatosphaeridium robustum. Sample 105-647A-69R, CC (2)041/3; max. dia. (incl. proc.), $66 \mu \mathrm{m}$ (uncert. v., us.). 4. Operculodinium sp. 2. Sample 105-647A-61R, CC (4)J50/1; max. dia., $34 \mu \mathrm{m}$ (subdv., subds.). 5, 9. Areosphaeridium diktyoplokus. 5, Operculum. Sample 105-647A-63R-1, 139-142 cm (K2)G36/2; max. length (incl. proc.), $109 \mu \mathrm{m}$ (lat. v., us.). 9, Sample 105-647A-63R-1, 139-142 cm (K2)J16/2; central body max. dia., $61 \mu \mathrm{m}$ (subap. v., subap. s.). 6. Homotryblium? sp. B. Sample 105-647A-25R, CC (1)J40/2; max. dia. (excl. proc.), $42 \mu \mathrm{m}$ (lat. v., ls.). 7. Operculodinium sp. 1. Sample 105-647A-65R-1, 117-121 cm (1)T31/3; max. dia., $54 \mu$ m (dv., ds.). 8. Tectatodinium sp. 1. Sample 105-647A-65R-1, 117-121 cm (1)J12/1; max. dia., $40 \mu \mathrm{m}$ (vv., ds.). 10. Dinocyst sp. F. Sample 105-647A-67R-4, 23-26 cm (Kl)Gl6/O; max. dia., $92 \mu \mathrm{m}$ (antap. v., mf.). 11. Dinocyst? sp. A. Sample 105-647A-70R-4, $42-45 \mathrm{~cm}$ (1)G24/2; max. dia., $91 \mu \mathrm{m}$ (dv., ds.). 12. Operculodinium sp. cf. O. centrocarpum. Sample 105-647A-67R-2, 28-31 cm (2)E32/0; max. dia (excl. proc.), $40 \mu \mathrm{m}$ (uncert. v., us.). 13. Cordosphaeridium gracile. Sample 105-647A-65R-1, 117-121 cm (2)F50/3; central body dia., $69 \mu \mathrm{m}$ (uncert. v., us.). 14. Cordosphaeridium inodes. Sample 105-647A-65R-1, 117-121 cm (2)K26/0; central body dia., $51 \mu \mathrm{m}$ (dv., ds.). 15. Cordosphaeridium cantharellum. Sample 105-647A-51R, CC (1)J51/4; central body dia., $54 \mu \mathrm{m}$ (uncert. v., us.). 